\title{
Skipped fluorination motifs: synthesis of building blocks, and comparison of lipophilicity trends with vicinal and isolated fluorination motifs
}

Robert I. Troup, ${ }^{a}$ Benjamin Jeffries, ${ }^{a}$ Raphael El-Bekri Saudain, ${ }^{a}$ Eleni Georgiou, ${ }^{a}$ Johanna

Fish, ${ }^{a}$ James S. Scott,${ }^{b}$ Elisabetta Chiarparin, ${ }^{b}$ Charlene Fallan, ${ }^{b}$ and Bruno Linclau ${ }^{a, *}$

${ }^{a}$ Chemistry, University of Southampton, Highfield, Southampton SO17 1BJ, UK.

${ }^{b}$ Medicinal Chemistry, Oncology R\&D, AstraZeneca, Cambridge CB4 0WG, UK

bruno.linclau@soton.ac.uk

\section{RECEIVED DATE}

TOC Graphic:

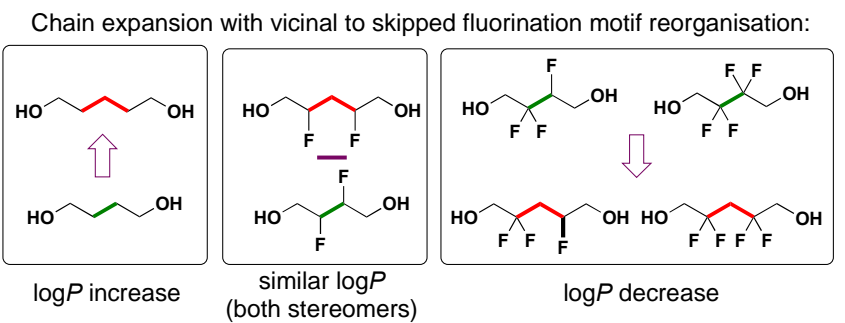

Abstract-Given there is an optimal lipophilicity range for orally bioavailable drugs, structural modifications applied in the drug development process are not only focused on optimizing bioactivity, but also on finetuning lipophilicity. Fluorine introduction can be used for both purposes. Insights in how fluorine introduction affects lipophilicity are thus of 
importance, and systematic series of fluorinated compounds with measured octanol-water partition coefficients are a powerful way to enhance our qualitative understanding in this regard, and are essential as input for computational $\log P$ estimation programs. Here we report a detailed comparison of all possible vicinal and skipped (1,3-substituted) fluorination motifs when embedded in structurally equivalent environments $\left(X-\mathbf{C F}_{\mathbf{n}} \mathbf{H}_{2-\mathbf{n}}-\mathbf{C F}_{\mathbf{m}} \mathbf{H}_{2-\mathbf{m}}-\mathrm{X}\right.$ versus $\mathrm{X}-$ $\mathbf{C F}_{\mathbf{n}} \mathbf{H}_{2-\mathbf{n}}-\mathrm{CH}_{2}-\mathbf{C F}_{\mathbf{m}} \mathbf{H}_{2-\mathbf{m}}-\mathrm{X}$, with $\mathrm{n}, \mathrm{m} \neq 0$ and $\left.\mathrm{X}=\mathrm{CH}_{2} \mathrm{OH}\right)$, to compounds with isolated fluorination ( $\mathrm{n} \neq 0 ; \mathrm{m}=0$, and including $\left.\mathrm{X}-\mathrm{CH}_{2}-\mathbf{C F}_{\mathbf{n}} \mathbf{H}_{2-\mathbf{n}}-\mathrm{CH}_{2}-\mathrm{X}, \mathrm{n}=0-2\right)$. It is shown that skipped fluorination is more powerful for $\log P$ reduction purposes compared to single or vicinal fluorination. Efficient stereoselective syntheses of the compounds with skipped fluorination motifs are reported, which where relevant can be made enantioselective using known chiral building blocks. These compounds, and some intermediates, will be of interest as advanced fluorinated building blocks.

\section{INTRODUCTION}

The realization of the critical importance of simultaneous optimization of physical properties and of bioactivities in the drug development process has been a major recent development in medicinal chemistry. ${ }^{1-8}$ Lipophilicity has been recognized as a useful proxy for a range of properties related to ADMET (Absorption, Distribution, Metabolism, Excretion, and Toxicity) of orally administered bioactive compounds, and is therefore an often-used parameter in the optimization process. ${ }^{3,7,9-11}$ It is defined as the partition coefficient $P$ of a compound between octanol and water, and expressed as its $\log$ arithm $(\log P)$. For ionizable compounds, partitioning is measured a particular $\mathrm{pH}$, and expressed as the logarithm of its distribution coefficient $\left(\log D_{\mathrm{pH}}\right)$. Chromatographic methods have been developed where retention times are related to lipophilicities. ${ }^{12,13}$ These methods have gained in popularity due to their simplicity and ability to generate a high-throughput of experimental data, but accuracies are naturally dependent on 
the quality of the training set used to establish the correlation between $\log P$ and retention time. The understanding of how lipophilicity is influenced by structural changes is of great importance in drug discovery. Systematic studies exploring structure-lipophilicity relationships, especially when using actual octanol-water partition coefficient values, are thus of great interest. Such studies also have importance for data-input in computational $\log P$ calculation efforts. ${ }^{14,15}$ While every structural modification of a compound will impact on its $\log P$ value, fluorine introduction has proven to be particularly useful in this regard, mainly due to a combination of its very strong electronegativity and its small size. ${ }^{16}$ Initiated by seminal work of K. Müller and colleagues, ${ }^{17-22}$ the influence of aliphatic chain fluorination on lipophilicities has been investigated by a number of groups, for example by investigating new motifs, ${ }^{23-28}$ introduction of fluorine on aliphatic systems ${ }^{29-33}$ or in amino acid side chains. ${ }^{34-36}$ A subset of these studies involve vicinal fluorination motifs (Figure 1). K. Müller was the first to discover the lower lipophilicity of the vicinal difluoro motif compared to the geminal analogues, ${ }^{19}$ and that the relative stereochemistry was not important (compare A2 with A3/A4 and B2-B4 with B5/B6). He also showed that a further extension to the trifluorinated motif as in $\mathbf{B 7 / B 8}$ only led to a small additional $\log P$ decrease. ${ }^{19}$ However, compared to the nonfluorinated "parents" A1/B1, a significant decrease in $\log P$ was obtained. In contrast, our group reported that the two vicinal difluoride compounds $\mathbf{C 2}$ and $\mathbf{C 3}$ only gave modest lipophilicity decreases compared to the nonfluorinated parent $\mathbf{C 1}$, but confirmed the irrelevance of relative stereochemistry. ${ }^{27}$ Hunter also recently reported that diastereoisomers of acyclic vicinal difluorinated compounds gave very similar $\log P$ values (not shown). ${ }^{14}$ Nevertheless, the lipophilicity decreasing effect of the vicinal difluoride motif introduction was convincingly demonstrated by Gilmour using Gilenya ${ }^{\circledR}$ analogues. ${ }^{37,} 38$ The nonfluorinated parent with a pentoxy chain D1 is significantly more lipophilic than D2, while the trifluoromethylated D3 only showed a modest decrease. Interestingly, two multivicinal 
analogues D4 and D5 were also synthesized, ${ }^{38}$ but showed similar lipophilicities to the vicinal difluorinated D2, although the effect of relative stereochemistry is now more pronounced.

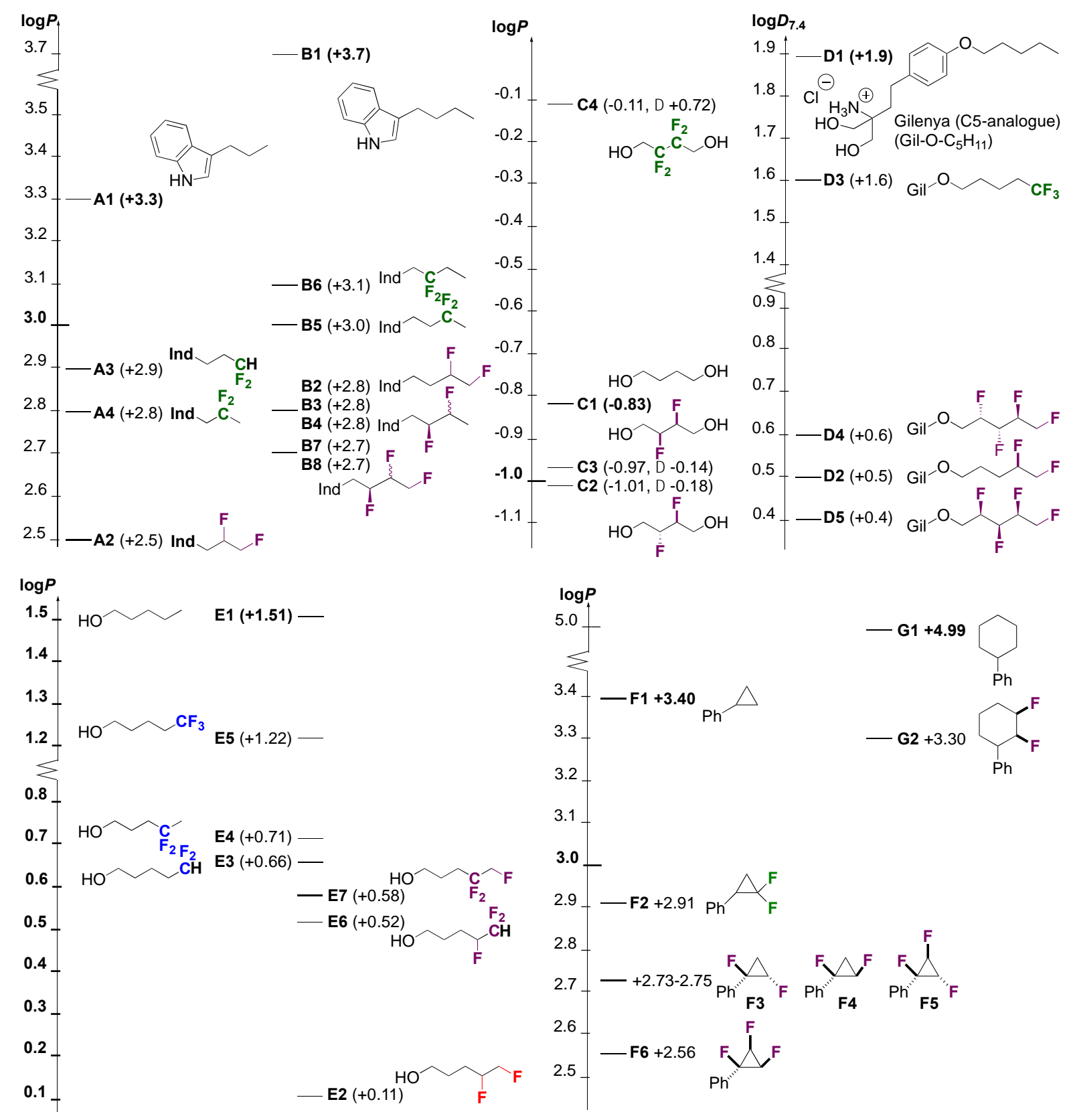

Figure 1. Precedent involving aliphatic vicinal and multivicinal fluorine motifs. 
Through analysis of all possible fluorination motifs on the pentan-1-ol 4- and 5-positions, we showed that 4,5-difluoropentan-1-ol E2 displayed the largest lipophilicity decrease of all motifs investigated, and that its $\log P$ value $(+0.11)$ is even lower than that of propan-1-ol $\left(+0.30\right.$, not shown), which has two fewer carbon atoms. ${ }^{23}$ It can be seen that the $\log P$ of $\mathbf{E} 2$ is much decreased compared to that of the corresponding geminal analogues $\mathbf{E 3 / E 4}$, and that the decrease is larger compared to that observed in series $\mathbf{A}$ and $\mathbf{B}$. We also showed that the corresponding 'motif extension' from a (geminal) trifluoromethyl group (E5) to the vicinal trifluorinated motifs as in E6/E7 also leads to significant $\log P$ decreases. O'Hagan has reported on geminal and vicinal difluorinated phenyl cyclopropanes, ${ }^{31,32}$ with the geminal difluorinated F2 being more lipophilic compared to the vicinal difluorinated compounds F3 and F4. Perhaps surprisingly, there was no measurable difference between the cis and trans-isomers. The allcis trifluorinated derivative F6 is the most polar in the series, with its diastereomer F5 having the same $\log P$ as the vicinal difluorinated analogues $\mathbf{F 3 / F 4}$. Finally, O'Hagan also reported on the significant $\log P$ decrease when introducing cis-vicinal difluorination on phenyl cyclohexane (G1 to G2).

In contrast to vicinal fluorination motifs, skipped fluorination motifs are only recently beginning to be investigated for their effect on lipophilicity. Our group showed that compared to vicinal fluorination motifs, the corresponding skipped motifs (Figure 2) had a much lower lipophilicity (compare E8/E9 with E10/E11). ${ }^{23}$ It is interesting to compare the skipped fluorination motif with its individual constituent motifs: the $\log P$ decrease caused by the skipped tetrafluorination motif in E10 is in between that of the monofluorinated E12 and the trifluoromethylated E14 (likewise for the other motif). Hence, the $\log P$ decrease caused by a skipped motif is less than the "sum" of the decrease obtained by introducing its constituents. O'Hagan has shown that introducing a skipped fluorine in G2, leading to G3, causes a large 
$\log P$ decrease. ${ }^{39}$ Introducing a fourth fluorine (G4) did not show much further decrease however.
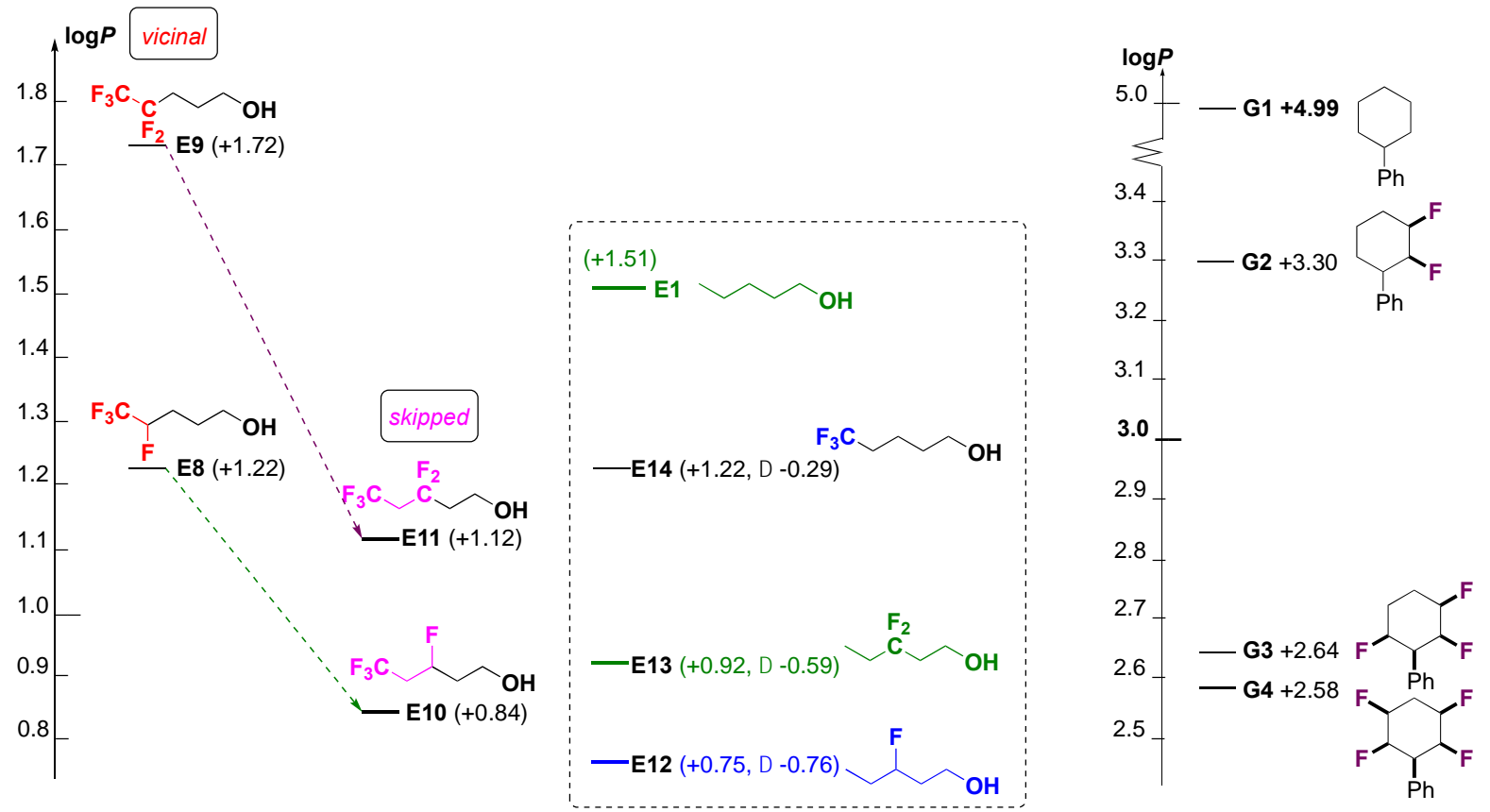

Figure 2. Vicinal and skipped fluorination motif matched pairs.

Compared to vicinal difluorination patterns, there are a number of synthetic methodologies reported for the synthesis of 1,3-skipped fluorination of aliphatic chains in small molecules. (Scheme 1). Relevant to the motifs reported herein, the Jacobsen group reported a direct introduction through oxidative ring-opening of substituted cyclopropanes with HF-pyridine, illustrated by the conversion of $\mathbf{1}$ to $2 .{ }^{40}$ The Carreira group reported the synthesis of fluorodanicalipin A 4, ${ }^{41}$ a fluorinated analogue of the chlorosulfolipid danicalipin A, by the simultaneous stereospecific nucleophilic deoxyfluorination of the corresponding 1,3-diol groups in 3. The repeating skipped monofluoro motif has been reported in fluoropolymers, though this chemistry has not been widely explored on small molecules. ${ }^{42}$ 
(a)

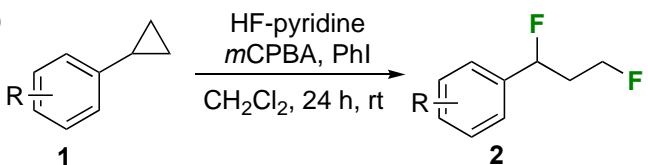

(b)

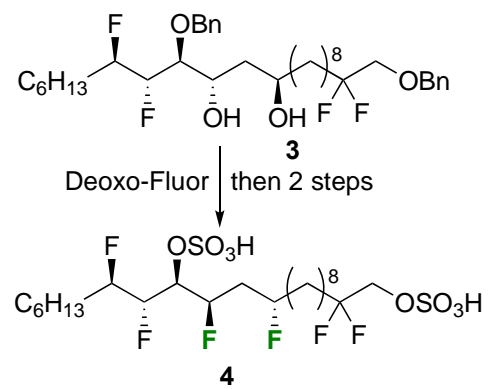

Scheme 1. Synthetic precedence examples for the skipped-difluoro motif.

Synthetically useful examples towards a skipped trifluorination motif within acyclic chains have not been reported, although methodology shown in Scheme 2 could in principle be applied. The Studer group reported that treatment of 5, obtained via 1,2-carboboration of the corresponding alkene, with SelectFluor and silver nitrate achieved a radical deboronofluorination to provide the skipped fluoro species 6 in a moderate yield. ${ }^{43}$ Another interesting approach was taken by Kitazume and Ishikawa, who synthesized the motif via alkene reduction of a fluorinated $\alpha, \beta$-unsaturated ester such as 7 with Baker's yeast, although a long reaction time (7 d) was required to obtain $8 .{ }^{44}$ Fuchikami and Ojima inadvertently produced the skipped fluoro pattern whilst investigating the transition metal-catalysed addition of perfluoroalkyl halides to alkenes. ${ }^{45}$ The perfluorooctylation of vinyl fluoride $\mathbf{1 0}$ with $\mathbf{9}$ afforded a mixture of the perfluoroalkyl iodides $\mathbf{1 1}$ and $\mathbf{1 2}$, which conveniently contained the skipped motif alongside a halide handle for further functionalisation at the terminal position. 

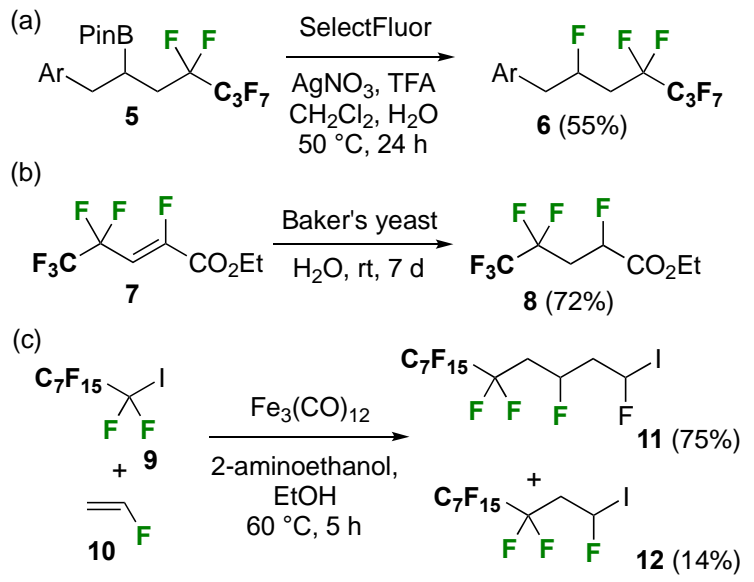

Scheme 2. Synthetic precedence for the skipped-trifluoro motif.

The skipped-tetrafluoro motif has perhaps received the most attention due to its widely reported use in fluorinated polymers and surfactants (Scheme 3). ${ }^{46-48}$ In a representative example, the Ameduri group reacted vinylidene fluoride 13 with iodide 14, and obtained telomers of various lengths containing skipped difluoromethylene groups (15). In their synthesis of fluorinated palmitic acid derivatives, the O'Hagan group employed sequential deoxyfluorinations in neat DAST to obtain the skipped-tetrafluoro motif in the centre of the long aliphatic chain: ${ }^{49}$ following the first deoxofluorination of ketone 16, the pendant alkene in $\mathbf{1 7}$ was converted to the epoxide and opened with pentylmagnesium bromide. Oxidation of the resultant alcohol to ketone $\mathbf{1 8}$ and treatment with DAST then afforded 19. Both fluorinations required neat DAST at elevated temperatures. In a related approach, the Chiechi group directly fluorinated $\beta$-dithiolane $\mathbf{2 1}$, obtained from the corresponding propargylic ketone 20, using HF-pyridine, to obtain 22. This was subsequently converted to the skipped-1,3tetrafluoro compound 23 with Morph-DAST. ${ }^{50}$ 
(a)

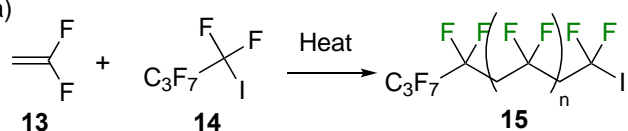

(b)<smiles>[131I-][Ba][Ba]</smiles>

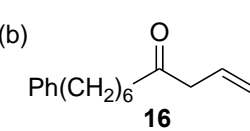
$\stackrel{\underset{50}{\circ} \mathrm{C} \text {, }}{\stackrel{\text { (neat) }}{\longrightarrow}}$

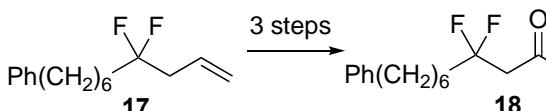<smiles>CCCCCCCCCCC</smiles><smiles>[SeH]</smiles>

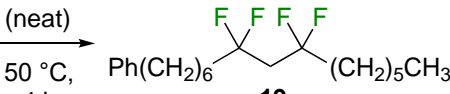

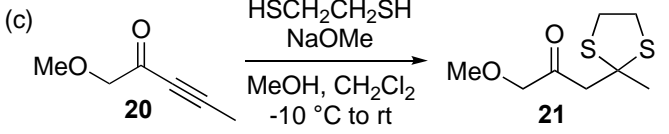

1,3-dibromo-5,5-

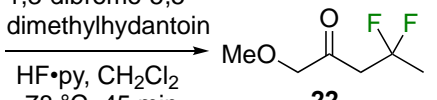
$-78^{\circ} \mathrm{C}, 45 \mathrm{~min}$

Scheme 3. Synthetic precedence for the skipped-tetrafluoro motif.

In this contribution, we report on a systematic investigation to compare internal vicinal fluorination motifs with their (internal) skipped counterparts, using the 1,4-butanediol and 1,5pentanediol scaffolds $\mathbf{C}$ and $\mathbf{H}$ (Figure 3). For this investigation, we opted to have a constant structural feature at the molecule termini, with the structural change focused on the extension of the two-carbon vicinal motif with the three-carbon skipped motif without any additional influence caused by fluorination motifs being at different distances from a polar functional group or aliphatic chain terminus.

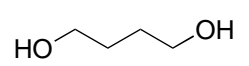

C1<smiles>OCC(F)C(F)CO</smiles><smiles>OCC(F)C(F)CO</smiles><smiles>OCC(F)C(F)(F)CO</smiles><smiles>OCC(F)(F)C(F)(F)CO</smiles><smiles>OCCCCCO</smiles><smiles>OCC(F)CC(F)CO</smiles><smiles>OCC(F)CC(F)CO</smiles><smiles>CC(F)(CO)CC(F)CO</smiles><smiles>OCC(F)(F)CC(F)(F)CO</smiles><smiles>OCCC(F)CO</smiles><smiles>OCCCC(F)CO</smiles><smiles>OCCC(F)CCO</smiles>

$\mathrm{H} 7$<smiles>OCCC(F)(F)CO</smiles><smiles>OCCCC(F)(F)CO</smiles><smiles>OCCC(F)(F)CCO</smiles>

H9<smiles>OCC(F)(F)C(F)(F)C(F)(CO)C(F)(F)CO</smiles>

Figure 3. The nonfluorinated parent substrates with the fluorination motif types studied. 
The synthesis ${ }^{51}$ and lipophilicities ${ }^{27}$ of $\mathbf{C 2}-\mathbf{C} 4$ have been reported and are included for discussion purposes, which also will involve comparison with monofluorinated and geminal difluorinated analogues C6,C7 and H6-H9, as well as with the hexafluorinated H10. The synthesis of $\mathbf{H 2}-\mathbf{H 5}$ employs different strategies compared to the literature precedence, and is, where relevant, fully stereoselective.

\section{RESULTS AND DISCUSSION}

\section{Synthesis}

The skipped target compounds H2-H5 - retrosynthetic analysis. The approach taken for the synthesis of these targets is shown in Scheme 4. While for the purposes of the lipophilicity measurements racemic compounds are adequate, we sought to develop synthetic routes that allowed enantioselective synthesis where applicable. For the anti-1,3-difluorinated H2, the final fluorine introduction was envisaged by deoxyfluorination of the fluorohydrin 24 , to be accessed by reductive opening of known lactone $\mathbf{2 5},{ }^{52}$ which synthesis has been reported by the Liotta group from lactone $\mathbf{2 6}$ using a fully diastereoselective electrophilic fluorination. Lactone $\mathbf{2 6}$ is easily procured from glutamic acid, ${ }^{53,54}$ conveniently enabling the synthesis of either enantiomer of $\mathbf{H 2}$ depending on the absolute configuration of the amino acid used. It is worth mentioning that direct enantioselective monofluorination of 1,5-pentanedialdehyde, for example using MacMillan methodology, ${ }^{55}$ which would directly yield $\mathbf{H 2}$ (after aldehyde reduction) was briefly investigated, but no formation of the desired product was ever observed. The synthesis of the meso-compound $\mathbf{H 3}$ was envisaged from the 2,4-dideoxy-difluorinated levoglucosan 28, with the required one-carbon $\mathrm{C}-\mathrm{C}$ bond cleavage and alcohol reduction being more than offset by the ease of the double fluorine introduction: one-pot bis-fluorination of the 
ditosylate 29 has been optimized on large scale by both the Giguère group and ourselves, ${ }^{56,57}$ making this an attractive starting point for $\mathbf{H 3}$.

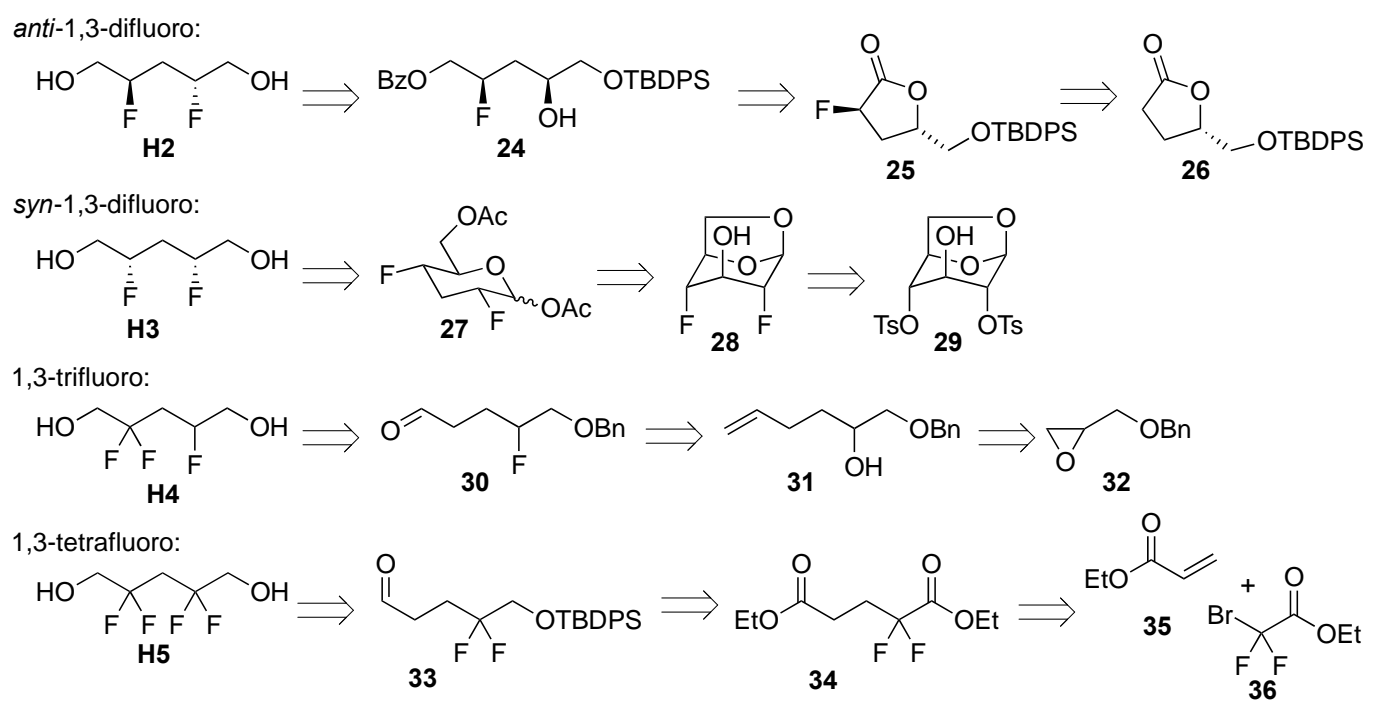

Scheme 4. Retrosynthetic analysis of the skipped fluorinated pentanediols

For the synthesis of $\mathbf{H 4}$, an electrophilic $\alpha$-difluorination/aldehyde reduction sequence as developed by the Lindsley group ${ }^{58,59}$ was envisaged, leading to $\mathbf{3 0}$ as precursor. The fluorination in $\mathbf{3 0}$ was envisaged to be achieved by deoxyfluorination of known alcohol $\mathbf{3 1}$, which can be obtained from epoxide opening of the commercially available building block $\mathbf{3 2}$. Both enantiomers of $\mathbf{3 2}$ are available, so this route could provide either enantiomer of $\mathbf{H 4}$, although only the racemic synthesis is reported here. To introduce the skipped tetrafluorination to obtain H5, we opted for a different strategy to O'Hagan and Chiechi's nucleophilic fluorination sequences. Instead, aldehyde electrophilic fluorination as also proposed for $\mathbf{H 4}$ was envisaged, with aldehyde $\mathbf{3 3}$ to be obtained from known diester $\mathbf{3 4},{ }^{60}$ which has been obtained by a fluorinated building block approach involving Michael-type methodology as originally described by the Kumadaki group. ${ }^{61,62}$ 
Anti-1,3-difluoro synthesis (H2). Lactone (S)-26 (Scheme 5) was obtained through a welldocumented sequence from L-glutamic acid $(\boldsymbol{S})-37,{ }^{53,} 54$ involving diazotization and concomitant intramolecular stereoretentive cyclisation to the lactone, reduction of the pendant acid to alcohol, and its protection as a tert-butyl diphenyl silyl ether. The electrophilic fluorination of $(\boldsymbol{S})$-26 with LiHMDS and NFSI gave $(\mathbf{2} \boldsymbol{R}, \mathbf{4 S})$-25 with complete diastereoselectivity, as reported by Liotta et al..$^{52}$ In our hands however, the reaction proved capricious, with a low $27 \%$ yield as our best result, compared to the reported $50-70 \%$. In a subsequent attempt the yield of $(\mathbf{2 R , 4 S ) - 2 5}$ was reduced to $10 \%$, but the by-product $\mathbf{3 8}$ was isolated in a significant $15 \%$ yield. This suggested that ammonia, originating from the ammonium chloride reaction quench, had reacted with the electrophilic lactone ring of $(\mathbf{2 R}, \mathbf{4 S})$ 25. As a result, the quench was altered to a minimum quantity of water, and the reaction mixture was carefully concentrated under reduced pressure and telescoped into the subsequent reduction. Treatment of the crude $(2 R, 4 S)-25$ with $\mathrm{NaBH}_{4}$ successfully provided a $50 \%$ yield of $(2 R, 4 S)-24$ across two steps.<smiles>NC(CCC(=O)O)C(=O)O</smiles>
(S)-37

(i) LHMDS,

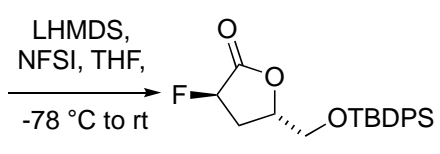

$(2 R, 4 S)-25(27 \%)$

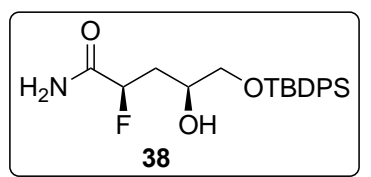

38

NFSI, THF,

$\underset{-78^{\circ} \mathrm{C} \text { to rt }}{\longrightarrow} \mathrm{NaBH}_{4}, \stackrel{\mathrm{F}}{\underset{\mathrm{CH}_{2} \mathrm{Cl}_{2}}{\longrightarrow}}$ OTBDPS $\mathrm{CH}_{2} \mathrm{Cl}_{2}$, EtOH, $\mathrm{rt}, 16 \mathrm{~h}$

$(2 R, 4 S)-24(50 \%)$

$(2 S, 4 R)-24(36 \%$, from $(R)-26)$
(2R,4S)-39 (67\%)

$(2 S, 4 R)-39(75 \%)$

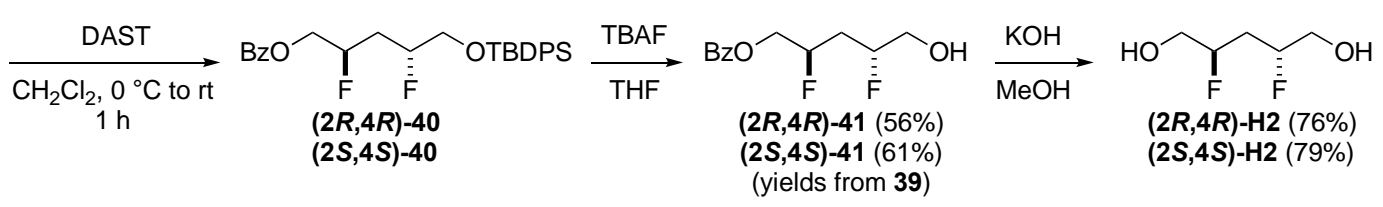

Scheme 5. The enantioselective synthesis of both enantiomers of the skipped difluorinated $\mathbf{H 2}$. 
Repeating this two-step sequence starting from $(\boldsymbol{R}) \mathbf{- 2 6}$ on a ten-fold increase in scale gave a reduced yield of $36 \%$. In both cases, selective protection of the primary alcohol as a benzoyl ester afforded 39 in moderate yields. This compound was then ready for the final key step in the synthesis: stereospecific nucleophilic deoxyfluorination to obtain the anti-1,3-difluoro compound 40. The use of two equivalents of DAST for one hour at $0{ }^{\circ} \mathrm{C}$ are reported to be compatible with a TBDPS group. ${ }^{63,64}$ The purity of the isolated material was low, however, treatment of the impure mixture with $\mathrm{TBAF}$ enabled isolation of pure $\mathbf{4 1}$ in good yields. Finally, treatment with $\mathrm{KOH}$ in methanol provided the diol $\mathbf{H 2}$ in a $76-79 \%$ yield. The measured optical activity of the $\mathbf{H} \mathbf{2}$ enantiomers confirmed the stereochemical outcome of the nucleophilic fluorination as occurring with inversion (as expected) without any trace of neighboring group participation of the protected alcohol, which is easily determined since the resulting retention would give the optically inactive meso-diastereomer $\mathbf{H 3}$.

Syn-1,3-difluoro synthesis (H3). The difluorinated sugar derivative 28 (Scheme 6) was obtained from levoglucosan (42), involving tosylation of the alcohols at positions 2 and 4 to obtain ditosylate 29 (not shown), and their stereo-retentive displacement with fluoride (45\% across the two steps). ${ }^{56,57}$ Reduction of the 3-OH group was achieved by the tin hydride-free conditions as reported by the Roberts group ${ }^{65}$ via the thiocarbonyl derivative $\mathbf{4 3}$.

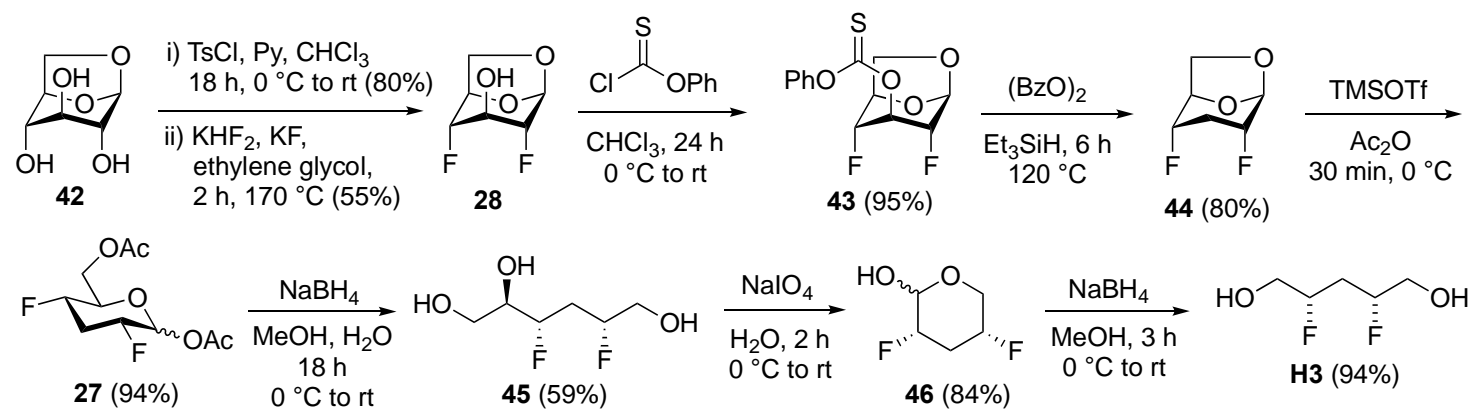

Scheme 6. Synthesis of the syn-1,3-difluorinated diol H3. 
The 1,6-anhydrobridge was opened using TMSOTf and acetic anhydride, to provide the acetylated pyranose $\mathbf{2 7}$ as an inseparable mixture of anomers. Simultaneous reduction of the hemiacetal and both esters gave triol $\mathbf{4 5}$ upon which oxidative cleavage of the vicinal diol was achieved to produce the lactol 46. Finally, reduction of this compound with sodium borohydride provided an excellent yield of $\mathbf{H 3}$.

Skipped trifluoro synthesis (H4). This synthesis commenced with known alcohol 31 (Scheme 7), which is accessible in one step from commercially available benzyl glycidol 32. ${ }^{66}$ Deoxyfluorination using NfF (nonafluorobutanesulfonyl fluoride) and triethylamine-HF to give $\mathbf{4 7}$ and oxidative cleavage of the alkene resulted in the required aldehyde $\mathbf{3 0}$ to effect the electrophilic difluorination step. This was achieved by sequential fluorination of the L-proline enamine intermediate when excess NFSI is present. ${ }^{58,59}$ The resulting 2,2-difluorinated aldehyde was reduced without purification to give trifluorinated alcohol $\mathbf{4 8}$, in an overall $81 \%$ yield from 30. Finally, removal of the benzyl protecting group using conditions reported by Jung and Lyster ${ }^{67}$ afforded the diol $\mathbf{H 4}$.

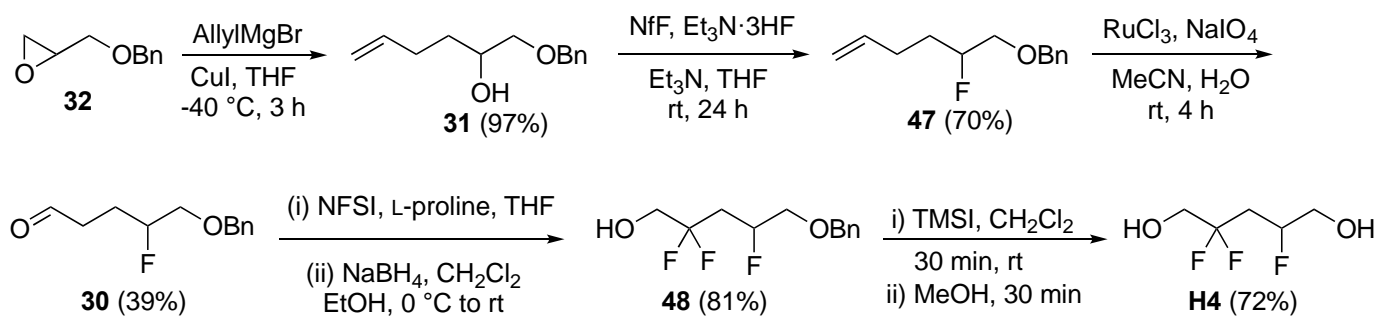

Scheme 7. Synthesis of the skipped trifluoro substrate $\mathbf{H 4}$. 
For the purposes of $\log P$ calculation the racemic compound was sufficient, however, alcohol 31 is equally accessible in enantiopure form from commercially available enantiopure benzyl glycidol.

Skipped tetrafluoro synthesis (H5). This sequenced commenced with the copper-catalysed conjugate addition $^{61,62}$ of ethyl bromodifluoroacetate 36 to ethyl acrylate 35 (Scheme 8 ). Acetic acid was added as a protic additive, due to the resulting improvement in yield reported by the Shin group. ${ }^{60}$ The adduct was directly subjected to $\mathrm{NaBH}_{4}$ treatment which led to the selective reduction of the more electrophilic ester group to give 49. Protection of the obtained alcohol as TBDPS ether $\mathbf{5 0}$ and partial ester reduction yielded aldehyde 33. Without further purification, this aldehyde was subjected to the same two-step difluorination/reduction sequence as before, which provided the skipped-tetrafluoro compound 51. Finally, alcohol deprotection afforded an excellent yield of the diol H5.
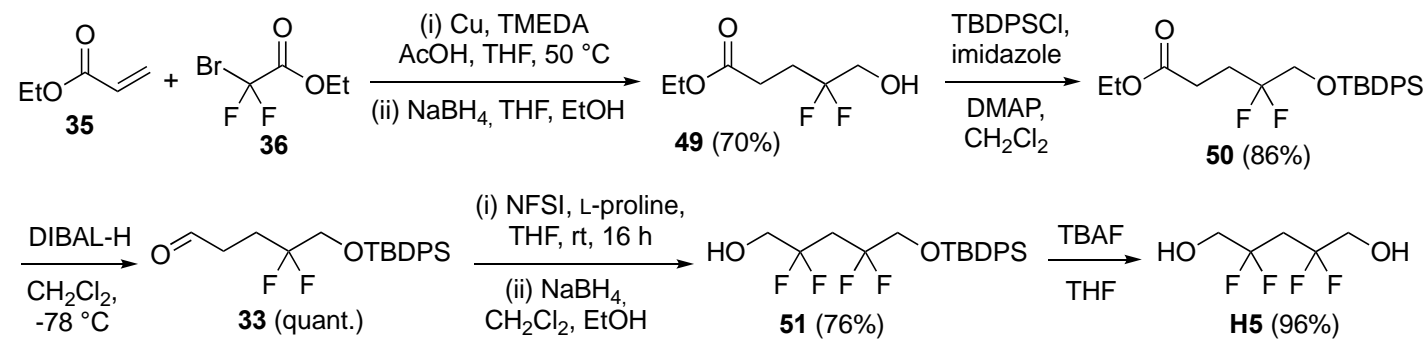

Scheme 8. Synthesis of the skipped-tetrafluoro diol H5.

The 1,5-pentanediol targets (H6, H7, H8). Benzoate cleavage of known $\mathbf{5 2}^{23}$ gave target $\mathbf{H 6}$ (Scheme 9a). Treatment of commercially available $\mathbf{5 3}$ with DAST afforded the fluorinated compound 54 in excellent yield, and subsequent reduction to the diol afforded the diol $\mathbf{H 7}$ (Scheme 9b). Finally, benzoate methanolysis of known $\mathbf{5 5}^{23}$ led to $\mathbf{H 8}$ (Scheme 9c). 
(a)<smiles>CC(C)(C)OCCCC(F)COCC(O)CO</smiles>

(b)<smiles>[R4][R16]#[R16]</smiles>

(c)

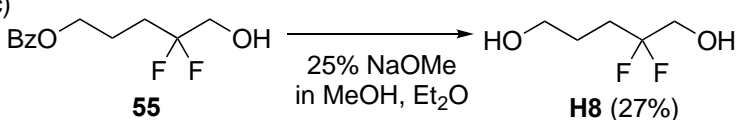

Scheme 9. Synthesis of mono- and geminal difluorinated 1,5-pentanediol targets.

The 1,4-butanediol targets $(\mathbf{C 5}, \mathbf{C 6}, \mathbf{C 7})$. Alcohol oxidation of known racemic syn-56 ${ }^{51}$ (Scheme 10a) using Dess-Martin periodinane gave ketone 57, and subsequent treatment with excess DAST efficiently led to the vicinal trifluoro motif in 58. Simultaneous TMSI-mediated ${ }^{67}$ deprotection of the two benzyl alcohols afforded the diol C5. Finally, benzoate methanolysis of known 59 and $\mathbf{6 0}$ (Scheme 10b) ${ }^{23}$ led to $\mathbf{C 6}$ and $\mathbf{C 7}$ in modest yield.

(a)<smiles>O=C(COCc1ccccc1)C(F)COCc1ccccc1</smiles><smiles>COCC(F)C(F)(F)COCC(F)C(F)(F)COCc1ccccc1</smiles>

$58(83 \%)$

C5 (81\%)

(b)

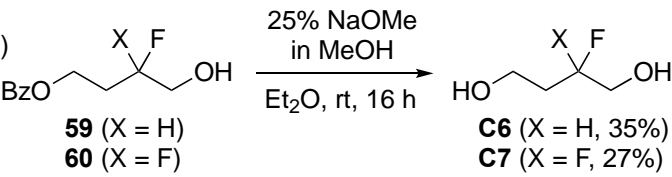

Scheme 10. Synthesis of the 1,4-butanediol targets.

\section{Lipophilicity}


The lipophilicity data for 1,4-butanediol $\mathbf{C 1}$ and its fluorinated derivatives are shown in Figure 4. Monofluorination (C6) leads to a $\log P$ decrease, while geminal difluorination $(\mathbf{C 7})$ leads to an almost equal $\log P$ increase. The contrast with the same types of fluorine introduction on the monohydroxylated analogue, 1-butanol I1 (inset, Figure 4), is interesting: monofluorination at its 2- or 3-positions, which have the same relative position of the fluorination relative to the $\mathrm{OH}$ groups in $\mathbf{C 6}$, leading to $\mathbf{I} 2$ and $\mathbf{I 3}$, leads to a much larger decrease in $\log P$. The same is true for geminal difluorination at these positions (I4 and I5), albeit much less pronounced for I4. This is a typical illustration of the context-dependence in $\log P$ modulation upon introduction of a given motif in similar parents having very different lipophilicities: 1,4-butanediol is much more polar than 1-butanol, hence the fluorine dipole effect will be reduced relative to hydrophobic effects such as introduction of hydrophobic surface and alcohol hydrogen bond basicity and lone pair polarizability reduction, resulting in a smaller $\log P$ decrease (for monofluorination, C6) or even in a $\log P$ increase (C7).

While the vicinal difluorinated derivatives $\mathbf{C 2 / C 3}$ are less lipophilic compared to $\mathbf{C 1}$ (see Figures 1/4), the vicinal trifluorinated motif in $\mathbf{C 5}$ leads to a higher $\log P$, and there is a further increase to the vicinal tetrafluorinated $\mathbf{C 4}$. The occurrence of antiperiplanar $\mathrm{C}-\mathrm{F}$ bonds, with their opposing dipole moments, will be an important reason for this. However, while the geminal difluorinated $\mathbf{C 7}$ is more lipophilic than parent $\mathbf{C 1}$, the corresponding vicinal difluorinated motifs (C2, C3, same fluorine count) are much more polar, leading to a lower $\log P$ than C1. This is consistent with Müller's original observation (see Figure 1). ${ }^{19}$

Extending monofluorination at the butanol 3- or 4-position to 3,4-difluorobutan-1-ol (I2/I3 to I6, Figure 4) has been shown to lead to a $\log P$ decrease. ${ }^{23}$ In contrast, application of such a motif extension in the 1,4-butanediol series leads to lipophilicity increases: introducing a fluorine adjacent to the existing $\mathrm{C}-\mathrm{F}$ group in $\mathbf{C 6}$ leads to $\mathbf{C 2} / \mathbf{C 3}$, which have a slightly higher lipophilicity. This contrasts with the $0.23 \log P$ decrease upon monofluorination of $\mathbf{C 1}$ to $\mathbf{C 6}$. 
Introducing a fluorine next to the $\mathrm{CF}_{2}$-group in $\mathbf{C 7}$ to give $\mathbf{C 5}$ leads to a (larger) $\log P$ increase. Introducing geminal difluorination adjacent to an existing $\mathrm{C}-\mathrm{F}$ group leads to a significant lipophilicity increase (C6 to $\mathbf{C 5}$ ), and the same observation is made going from $\mathbf{C 7}$ to $\mathbf{C 4}$. This contrasts with a modest $\log P$ increase upon geminal difluorination of $\mathbf{C 1}$. Hence, for the 1,4butanediol parent, vicinal fluorination serves to increase lipophilicities.



Figure 4. Lipophilicities of fluorinated 1,4-butanediol derivatives, with comparison to relevant fluorinated 1-butanols. Lipophilicity scales for the compound series are normalized to their nonfluorinated parents.

For the 1,5-pentanediol derivatives (Figure 5), C2-monofluorination of H1 to give H6 leads again to a $\log P$ decrease, and geminal C2-difluorination (H8) to a $\log P$ increase. With 1,5 pentanediol $\mathbf{H 1}$ being less polar than 1,4-butanediol C1, the $\log P$ decrease upon 
monofluorination of $\mathbf{H 1}$ is larger than that of $\mathbf{C 1}$ (see Figure S2 for direct comparison). The same context-dependency derived effects apply to the geminal difluorinated derivatives, and also explain, as observed for $\mathbf{C 1}$, why geminal difluorination to $\mathbf{H 8}$ leads to a $\log P$ increase, while for E1. This leads to a $\log P$ decrease.

There is a difference in trend when comparing mono- and difluorination between the 2- and 3-positions of H1: the $\mathrm{C} 3$-monofluorinated $\mathbf{H} 7$ has a higher $\log P$ than the $\mathrm{C} 2$-monofluorinated H6, but the C3-difluorinated $\mathbf{H 9}$ has a lower $\log P$ compared to the C2-difluorinated $\mathbf{H 8}$. This can be qualitatively explained, over and above any context-dependency issues, by taking into account the relative distance between the fluorination sites and both $\mathrm{OH}$ groups, and comparing these with the 1-pentanol (E1) data (inset, Figure 5): 2,2-difluoropentan-1-ol (E17) is much more lipophilic than its geminal fluorination regioisomers $\mathbf{E 5}$ and E15, resulting in $\mathbf{H 8}$ to have a higher $\log P$ then H9. Conversely, 4-fluoropentan-1-ol E3 is much less lipophilic, which must dominate the $\log P$ of $\mathbf{H 6}$, leading to its lower value.

Introduction of the skipped difluorination motif leads to a strong $\log P$ reduction, although the influence of the relative stereochemistry is again minimal. Hence, skipped difluorination is much less lipophilic than geminal difluorination (cf H8/H9). Even the skipped trifluoromotif in $\mathbf{H 4}$ leads to a $\log P$ decrease compared to $\mathbf{H 1}$, however, the skipped tetrafluorinated $\mathbf{H 5}$ has a higher $\log P$.

Also, in contrast to the butanediol scenario, introducing a second fluorine in the skipped position to an existing $\mathrm{C}-\mathrm{F}$ (H6 to $\mathbf{H 2 / H 3}$ ), or to an existing $\mathrm{CF}_{2}$ ( $\mathbf{H 8}$ to $\mathbf{H 4}$ ) leads to a lipophilicity decrease. The $\log P$ of $\mathbf{H 4}$ lies in between that of the monofluorinated $\mathbf{H 6}$ and difluorinated H8. Introducing a $\mathrm{CF}_{2}$ in the skipped position to an existing $\mathrm{C}-\mathrm{F}$ ( $\mathbf{H 6}$ to $\mathbf{H 4}$ ) and to an existing $\mathrm{CF}_{2}$-group (H8 to $\mathbf{H 5}$ ) leads to a $\log P$ increase, albeit a rather modest one. 


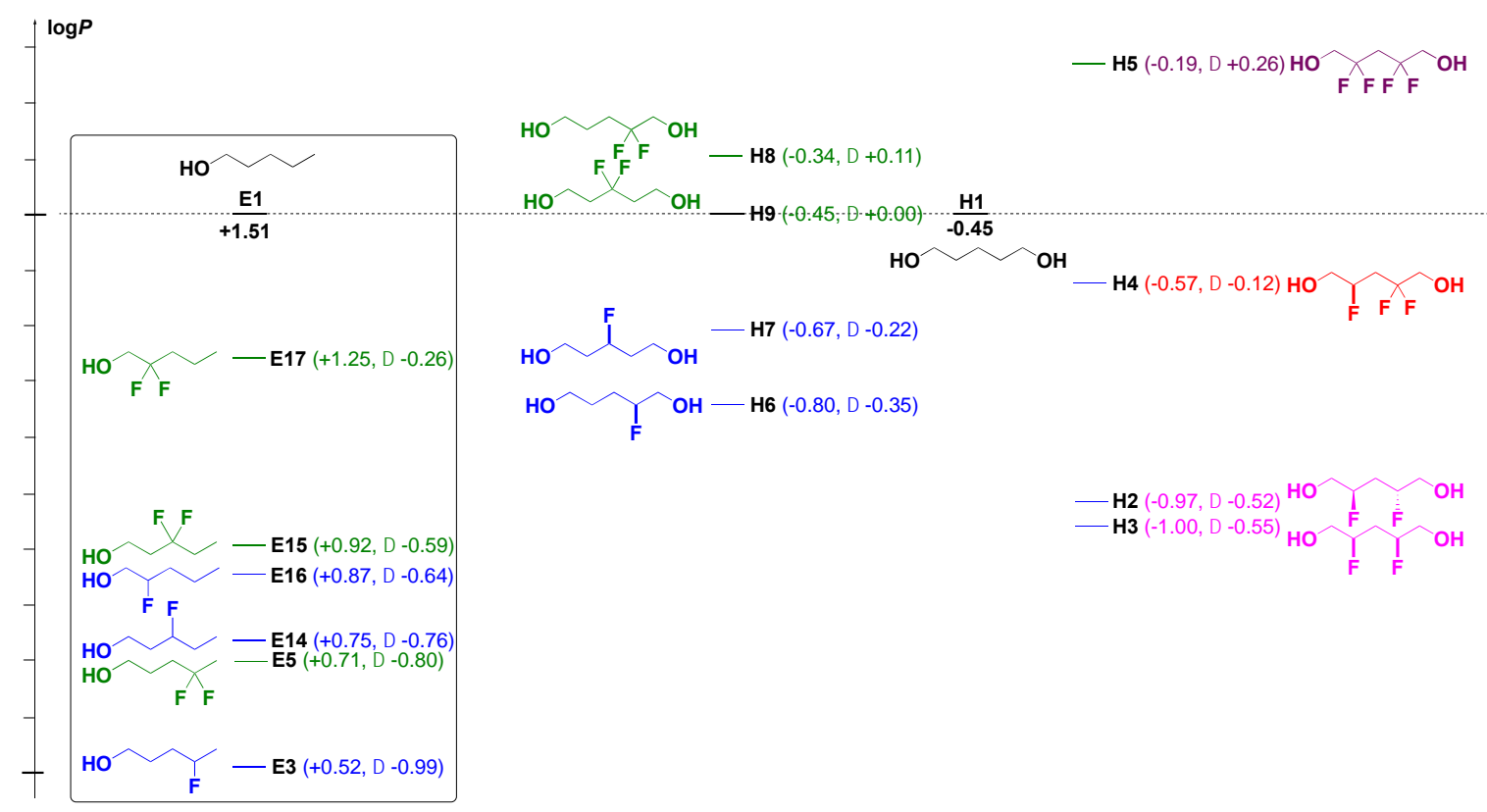

Figure 5. Lipophilicities of fluorinated 1,5-pentanediol derivatives, with comparison to relevant fluorinated 1-pentanols. Lipophilicity scales for the compound series are normalized to their nonfluorinated parents.

A direct comparison of the vicinal and the skipped motifs is given in Figure 6. It is immediately apparent that for a given motif comparison, the lipophilicities of the 1,5pentanediol compounds are similar or lower compared to these of the corresponding 1,4butanediol analogues despite the extra $\mathrm{CH}_{2}$-group. This is in stark contrast with the difference between the nonfluorinated $\mathbf{C 1}$ and H1. So, the 1, $\omega$-diols with the vicinal and skipped difluoride motifs have similar $\log P$ values (cf $\mathbf{C 2} / \mathbf{C 3}$ with $\mathbf{H 2} / \mathbf{H 3}$ ), and for the tri- and tetrafluorinated versions, the $\mathrm{C} 5$ chain compounds have an even $\operatorname{lower} \log P$ ( $\mathrm{cf} \mathbf{C} 4$ with $\mathbf{H 5}$ and $\mathbf{C 5}$ with H4). This can be easily qualitatively explained by dipole arguments: in C5 and C4 there will be abundant conformations with antiperiplanar $\mathrm{C}-\mathrm{F}$ bonds, while in the skipped motifs the $\mathrm{C}-\mathrm{F}$ bonds will polarise antiperiplanar $\mathrm{C}-\mathrm{H}$ bonds (the chemical shift of the central 
methylene group in $\mathbf{H 5}$ is $2.67 \mathrm{ppm})$. The large difference between the skipped tetrafluorinated H5 and the hexafluorinated H10 is also worth noting.

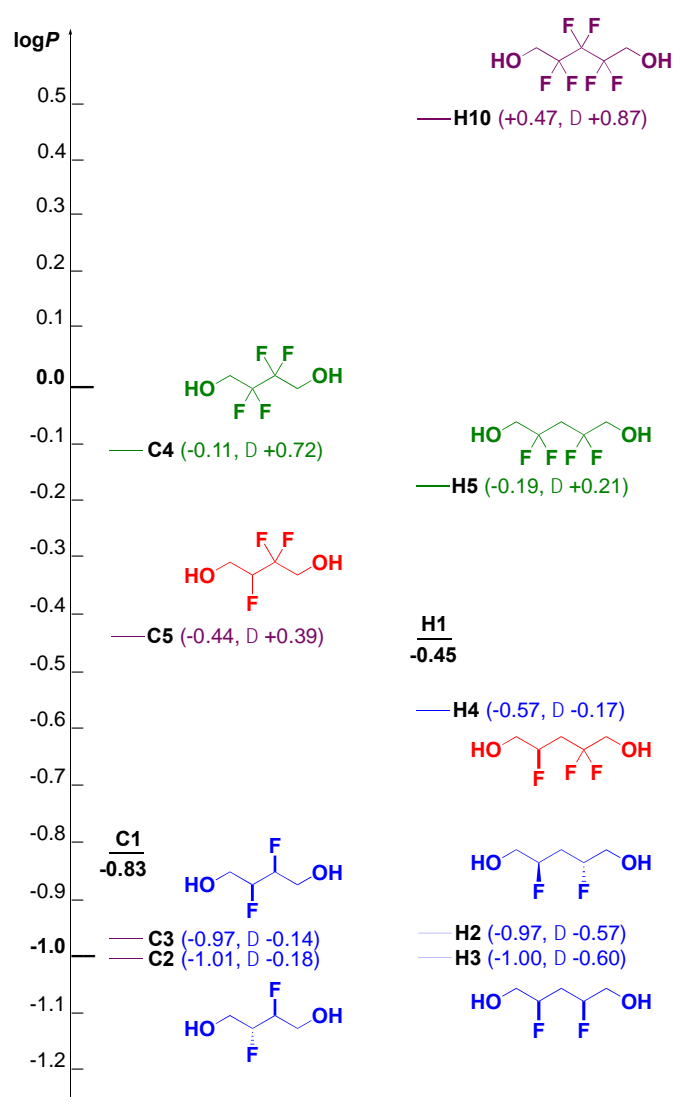

Figure 6. Comparison between vicinal and skipped fluorination motifs.

The data in Figure 6 are also shown on a normalized scale to the butanediol derivatives (Figure 7), which nicely emphasises the relative lipophilicity differences in light of a onecarbon chain extension: with mono- or geminal difluorination, there is a lipophilicity increase, with vicinal difluorination, the $\log P$ remains very similar, while with vicinal tri- and tetrafluorination, a $\log P$ reduction is obtained. 


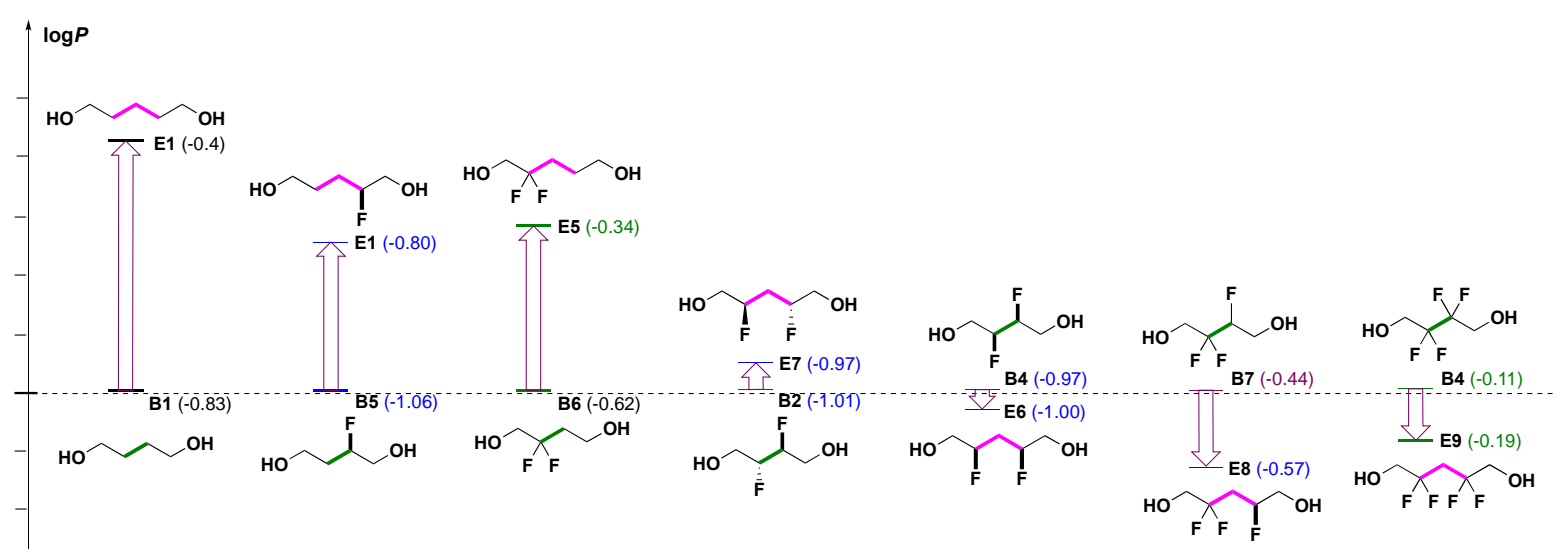

Figure 7. Chain extension with concomitant vicinal to skipped motif reorganisation.

The difference in lipophilicities between 1,4-butanediol $\mathbf{C 1}$ and 1,5-pentanediol $\mathbf{H 1}$ and that of their stable perfluorinated analogues $\mathbf{C 4}$ and $\mathbf{H 1 0}$ (Figure 8) is worth noting.

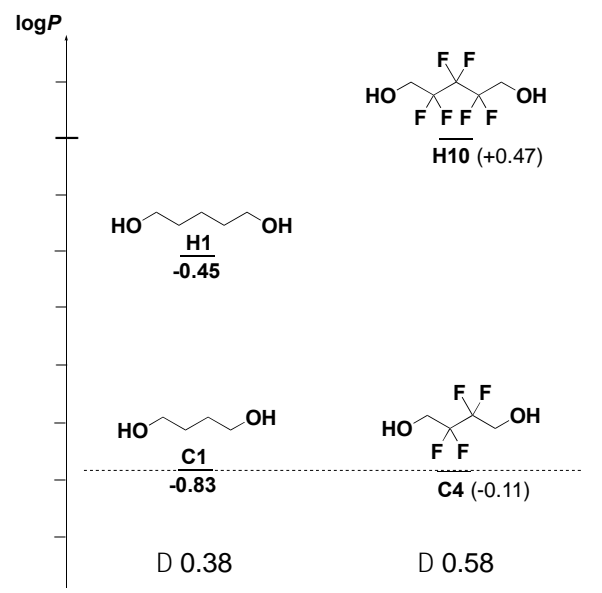

Figure 8. Comparing apparent lipophilicity contributions of $\mathrm{CH}_{2}$ vs $\mathrm{CF}_{2}$ groups. Lipophilicity scales for the compound series are normalized to the butanediol derivatives.

The increase in lipophilicity is much greater when inserting a $\mathrm{CF}_{2}$ group (C4 to $\left.\mathbf{H 1 0}\right)$ compared to a $\mathrm{CH}_{2}$ group ( $\mathbf{C 1}$ to $\mathbf{H 1}$ ). The very similar chemical shift values of the $\mathrm{CH}_{2} \mathrm{OH}$ hydrogens in $\mathbf{C 4}$ and $\mathbf{H 1 0}$ (4.05 vs 4.10, $\mathrm{CDCl}_{3}$ ) suggest that the tetrafluorinated moiety has a similar effect on alcohol polarizability as the hexafluorinated subunit, indicating that the larger 
lipophilicity increase upon inserting a difluoromethylene group is due to its larger hydrophobicity vs a methylene group. In comparing hydrocarbon and fluorocarbon containing amphiphilic compounds, differences in critical micelle concentration values led Hatanaka et al to conclude that the hydrophobicity of a $\mathrm{CF}_{2}$ group is 1.5 times that of a $\mathrm{CH}_{2}$ group. ${ }^{68} \mathrm{However}$, the context dependence of lipophilicity values do not allow us to derive similar conclusions from the observed lipophilicity differences: with the fluorinated derivatives being more apolar, the relative influence of hydrophobic surface should be reduced, so the $\log P$ difference could have been expected to be even larger. In addition, there is a further polarity effect at play: in the tetrafluoro motif all dipoles potentially compensate each other, while this is not possible for the hexafluorinated motif. Hence, the latter motif will be comparatively more polar than the tetrafluorinated motif, indicating that the lipophilicity difference is even smaller than would have been the case if just hydrophobic $\mathrm{CH}_{2}$ vs $\mathrm{CF}_{2}$ surface difference considerations were made.

The experimental $\log P$ values of the 1,4- and 1,5-diol derivatives were also compared against a set of $\operatorname{cog} P$ values (see supporting information for full details). Correlation values of most (fragment-based) calculation methods hovered between 0.8 and 0.9 , which is less than we have typically observed for the fluorinated alkanol derivatives. ${ }^{23,25}$

\section{CONCLUSION}

Lipophilicities of the complete series of vicinal fluorination motifs within the 1,4-butanediol scaffold have been systematically compared with these of the corresponding skipped fluorination motifs within the 1,5-pentanediol scaffold. For each of these series, comparison with all possible monofluorinated and geminal difluorinated analogues is made, and with the perfluorinated analogues. This is the first study comparing the lipophilicity of these motifs. 
The $C_{2}$-symmetric skipped difluorinated enantiomers were synthesized from their respective enantiopure glutamic acid building blocks in 9 steps, and the meso-skipped difluorinated pentanediol was obtained from levoglucosan in 8 steps. In both cases, symmetrization to the diol only occurred in the final steps, with these routes generating monoprotected building blocks that would allow facile introduction of these advanced fluorinated substrates in target compounds. The skipped trifluorinated pentanediol was synthesized starting from protected glycidol in 6 steps, while the skipped tetrafluorinated target was obtained in 7 steps from ethyl bromodifluoroacetate.

For both the vicinal and skipped fluorination motifs, the $\log P$ increased with increasing fluorine number. For the vicinal fluorination, only the difluorinated analogue had a lower $\log P$ compared to the nonfluorinated parent, while for the skipped fluorination, the trifluorinated motif also had a $\operatorname{lower} \log P$. In absolute values, 1,4-butanediol with vicinal difluorination (syn or anti) has the same $\log P$ as 1,5-pentanediol with skipped difluorination (syn or anti), despite the extra methylene group in the latter (1,5-pentanediol itself has a higher $\log P$ than 1,4 butanediol). For the corresponding trifluorinated and tetrafluorinated situations, the pentanediols with the skipped motif have even $\operatorname{lower} \log P$ values compared to the equivalent butanediols.

Starting from both the monofluorinated and geminal difluorinated 1,4-diols, a small $\log P$ increase is observed when introducing monofluorination at the adjacent carbons, which is much larger when introducing geminal difluorination at these carbons. In contrast, starting from both the monofluorinated and geminal difluorinated 1,5-diols, introducing monofluorination at the skipped carbon leads to a $\log P$ decrease, which only becomes a small increase when geminal difluorination is introduced there. 
Hence, all these observations illustrate the greater lipophilicity reducing power of the skipped motif, and emphasise the lipophilicity increasing power of perfluoroalkylidene moieties.

As an aside, the $\log P$ difference between the nonfluorinated 1,4-butanediol and 1,5-pentanediol parents was compared with the lipophilicity difference between their stable perfluorinated congeners. This difference is smaller for the nonfluorinated diols ( 0.38 vs $0.58 \log P$ units $)$, and shows the larger hydrophobicity of a $\mathrm{CF}_{2}$ group compared to a $\mathrm{CH}_{2}$ group.

The synthetic work towards the skipped building blocks will be of general interest for applications in organic and medicinal chemistry. The insights regarding lipophilicity of the vicinal and skipped motifs will find application in medicinal chemistry, in particular in drug development involving compounds with hydrocarbon/lipid chain appendages (eg many steroids, prostaglandins etc), but also taking account of possible metabolic stability issues. ${ }^{69-71}$ Finally, the lipophilicity data sets will find application in the development of computational approaches towards lipophilicity estimations.

\section{EXPERIMENTAL SECTION}

\section{General conditions}

All air/moisture sensitive reactions were carried out under an atmosphere of argon in glassware heated under high vacuum. Where required, reactions were heated using a heating block (DrySyn). All reagents and solvents were bought from commercial sources and used as supplied unless otherwise stated. Flash column chromatography was performed on silica gel (MERCK Geduran $60 \AA$ A, particle size 40-63 $\mu \mathrm{m}$ ) under pressure unless otherwise stated. All reported solvent mixtures are volume measures. Reactions were monitored by TLC (MERCK Kieselgel 60 F254, aluminium sheet), visualized under UV light (254 nm), and/or by staining 
with $\mathrm{KMnO}_{4}(10 \%$ aq.). Fourier-transform infrared (IR) spectra are reported in wavenumbers $\left(\mathrm{cm}^{-1}\right)$ and were recorded as neat films on a Thermo Scientific Nicolet iS5 spectrometer using neat samples (solid or liquid) unless otherwise stated. Electrospray mass spectra were obtained from a Waters Acquity TQD mass tandem quadrupole mass spectrometer, and recorded in m/z (abundance). HRMS was obtained from a Bruker Daltonics MaXis time of flight (TOF) mass spectrometer (ESI), a Bruker Daltonics solariX FT-ICR mass spectrometer equipped with a 4.7T superconducting magnet $(\mathbf{2 7}, \mathbf{4 3}, \mathbf{4 4}, \mathbf{4 5}, \mathbf{4 6}, \mathbf{H 3})$, a Thermo MAT900 XP double focusing sector mass spectrometer (CI), or a LECO Pegasus HRT+ TOF mass spectrometer (EI). Samples were run in HPLC MeOH or MeCN. Optical rotations were recorded on an Optical Activity POLAAR 2001 at $589 \mathrm{~nm}$. Melting points were obtained in an open capillary and are uncorrected. ${ }^{1} \mathrm{H},{ }^{13} \mathrm{C}$, and ${ }^{19} \mathrm{~F}$ NMR spectra were recorded in $\mathrm{CDCl}_{3}$ or $\mathrm{MeOD}$ using a Bruker Ultrashield 400 or $500 \mathrm{MHz}$ spectrometer. ${ }^{1} \mathrm{H}$ and ${ }^{13} \mathrm{C}$ chemical shifts $(\delta)$ are quoted in ppm relative to residual solvent peaks as appropriate. ${ }^{19} \mathrm{~F}$ spectra were externally referenced to $\mathrm{CFCl}_{3}$. The coupling constants $(\mathrm{J})$ are given in Hertz $(\mathrm{Hz})$. The coupling constants have not been averaged. The NMR signals were designated as follows: s (singlet), d (doublet), $t$ (triplet), q (quartet), quin (quintet), sxt (sextet), spt (septet), m (multiplet), or a combination of the above. For all novel compounds, detailed peak assignment was performed through the combined use of HSQC, HMBC, and COSY NMR experiments as required.

\section{Determination of $\log P$}

Lipophilicities of the fluorinated alkanols were determined using a previously published protocol: ${ }^{27}$ to a $10 \mathrm{~mL}$ pear-shaped flask was added the compound $(1.0-10 \mathrm{mg})$ for $\log P$ determination, the reference compound (1.0-10 mg, with known $\log \mathrm{P}$ value, e.g., 2,2,2trifluoroethanol, $\log P:+0.36)$, water $(2 \mathrm{~mL})$, and n-octanol $(2 \mathrm{~mL})$. The resulting biphasic mixture was stirred (at $\pm 600 \mathrm{rpm}$ ) for $2 \mathrm{~h}$ at $25^{\circ} \mathrm{C}$ and then left without stirring for $16 \mathrm{~h}$ at 25 ${ }^{\circ} \mathrm{C}$ to allow phase separation. An aliquot of $0.5 \mathrm{~mL}$ was taken from each phase using $1 \mathrm{~mL}$ 
syringes with long needles and added to two separate NMR tubes. A deuterated NMR solvent $\left(0.1 \mathrm{~mL}\right.$, e.g., acetone- $\left.d_{6}\right)$ or a capillary tube containing deuterated NMR solvent was added to the NMR tubes to enable signal locking. Because of the volatility of the used compounds, the NMR tubes were sealed using a blowtorch. For NMR samples with directly added deuterated solvent, the tubes were inverted 20 times for mixing. For ${ }^{19} \mathrm{~F}\left\{{ }^{1} \mathrm{H}\right\}$ NMR experiments, NMR parameters were set as follows: D1 $30 \mathrm{~s}$ for the octanol sample, D1 $60 \mathrm{~s}$ for the water sample, and O1P centred between two diagnostic fluorine peaks. If needed, an increased number of transients (NS) and/or narrower spectral window (SW) for a good S/N ratio (typically > 300) was applied. After NMR data processing, integration ratios $\rho_{\text {oct }}$ and $\rho_{\text {aq }}$ ( $\rho_{\text {oct }}$ is defined as the integration ratio between the compound and the reference compound in the octanol sample; likewise for $\left.\rho_{\text {aq }}\right)$ were obtained and used in the equation $\log P_{\mathrm{X}}=\log P_{\text {ref }}+\log \left(\rho_{\text {oct }} / \rho_{\text {aq }}\right)$ to obtain the $\log P$ value of the compound. The $\log P$ measurement of each compound was run in triplicate. $\log P$ values of nonfluorinated compounds were taken from the literature where available.

\section{Synthesis}

Targets C4, H9, and H10 were commercially available.

(2R,4S)-5-((tert-Butyldiphenylsilyl)oxy)-2-fluoropentane-1,4-diol

$((2 R, 4 S)-24)$.

Synthesized according to a modified procedure of Liotta et al. ${ }^{52}$ To a stirred solution of lactone $(S)-26^{54}(2.00 \mathrm{~g}, 5.64 \mathrm{mmol})$ and NFSI $(1.78 \mathrm{~g}, 5.64 \mathrm{mmol})$ in dry THF $(25 \mathrm{~mL})$ at $-78{ }^{\circ} \mathrm{C}$, LiHMDS (1M in THF, $6.80 \mathrm{~mL}, 6.80 \mathrm{mmol}$ ) was added dropwise over $45 \mathrm{~min}$. The solution was stirred at $-78{ }^{\circ} \mathrm{C}$ for $2 \mathrm{~h}$ then warmed to $\mathrm{rt}$ and stirred for $14 \mathrm{~h}$. The reaction was quenched by slow addition of water $(0.12 \mathrm{~mL})$, stirred for $30 \mathrm{~min}$, and carefully concentrated in vacuo (bath temperature $\leq 30^{\circ} \mathrm{C}$ ). The residue was redissolved in $\mathrm{CH}_{2} \mathrm{Cl}_{2}(50 \mathrm{~mL})$, dried over $\mathrm{MgSO}_{4}$, and concentrated in vacuo to afford crude $(2 R, 4 S)-25$. This was redissolved in a mixture of dry $\mathrm{CH}_{2} \mathrm{Cl}_{2}(3.4 \mathrm{~mL})$ and $\mathrm{EtOH}(2.3 \mathrm{~mL})$, to which $\mathrm{NaBH}_{4}(0.533 \mathrm{~g}, 14.1 \mathrm{mmol})$ was added 
portionwise at $0{ }^{\circ} \mathrm{C}$. The solution was stirred at $\mathrm{rt}$ for $16 \mathrm{~h}$ then cooled to $0{ }^{\circ} \mathrm{C}$ and quenched by cautious addition of sat. aq. $\mathrm{NH}_{4} \mathrm{Cl}(10 \mathrm{~mL})$. The mixture was stirred vigorously for $30 \mathrm{~min}$ at $\mathrm{rt}$. The phases were separated and the aqueous phase extracted with $\mathrm{CH}_{2} \mathrm{Cl}_{2}(3 \times 10 \mathrm{~mL})$. The combined organic layers were dried over $\mathrm{MgSO}_{4}$ and concentrated in vacuo. The crude product was purified by flash column chromatography (hexane/EtOAc 40:60) to afford the title compound $(\mathbf{2} \boldsymbol{R}, \mathbf{4 S})-\mathbf{2 4}$ as a colourless crystalline solid (1.06 g, 50\% over two steps). $\mathrm{R}_{\mathrm{f}} 0.24$ (hexane/EtOAc 40:60); mp 78-79 ${ }^{\circ} \mathrm{C}\left(\mathrm{CH}_{2} \mathrm{Cl}_{2}\right)$; $[\alpha]_{\mathrm{D}}{ }^{19}-1.3$ (c 1.0, $\mathrm{CHCl}_{3}$ ); IR 3362 (br. w), 3071 (w), 2930 (m), 2858 (m), 1427 (m), $1111(\mathrm{~s}) \mathrm{cm}^{-1} ;{ }^{1} \mathrm{H}$ NMR (400 MHz, $\left.\mathrm{CDCl}_{3}\right) \delta 7.69$ 7.66 (4H, m, Hph), 7.49-7.39 (6H, m, Hph), 4.77 (1H, dqd, $J=47.9,5.7,3.7$ Hz, H2), 4.01-3.95 (1H. m. $\left.\mathrm{H}_{4}\right), 3.85-3.72\left(2 \mathrm{H}, \mathrm{m}, \mathrm{H}_{1}\right), 3.69\left(1 \mathrm{H}, \mathrm{dd}, J=10.3,3.6 \mathrm{~Hz}, \mathrm{H}_{5}\right), 3.59(1 \mathrm{H}, \mathrm{dd}, J=10.3$, $\left.7.2 \mathrm{~Hz}, \mathrm{H}_{5}\right)^{\prime}, 2.8\left(1 \mathrm{H}, \mathrm{d}, J=2.5 \mathrm{~Hz}, \mathrm{OH}_{4}\right), 2.49\left(1 \mathrm{H}, \mathrm{t}, J=5.1 \mathrm{~Hz}, \mathrm{OH}_{1}\right), 1.90-1.80(2 \mathrm{H}, \mathrm{m}$, $\left.\mathrm{H}_{3}\right), 1.10\left(9 \mathrm{H}, \mathrm{s}, \mathrm{H}_{t \mathrm{Bu}}\right) \mathrm{ppm} ;{ }^{13} \mathrm{C}\left\{{ }^{1} \mathrm{H}\right\} \mathrm{NMR}\left(101 \mathrm{MHz}, \mathrm{CDCl}_{3}\right) \delta 135.5\left(\mathrm{CPh}_{\mathrm{Ph}}\right), 132.9\left(\mathrm{CPh}_{\mathrm{Ph}}\right), 129.9$ $\left(\mathrm{CPh}_{\mathrm{Ph}}\right), 127.8\left(\mathrm{CPh}_{\mathrm{Ph}}\right), 91.8\left(\mathrm{~d}, J_{\mathrm{C}-\mathrm{F}}=168.7 \mathrm{~Hz}, \mathrm{C}_{2}\right), 68.3\left(\mathrm{~d}, J_{\mathrm{C}-\mathrm{F}}=5.1 \mathrm{~Hz}, \mathrm{C}_{4}\right), 67.5\left(\mathrm{C}_{5}\right), 64.2(\mathrm{~d}$, $\left.J_{\mathrm{C}-\mathrm{F}}=22.7 \mathrm{~Hz}, \mathrm{C}_{1}\right), 34.1\left(\mathrm{~d}, J_{\mathrm{C}-\mathrm{F}}=20.5 \mathrm{~Hz}, \mathrm{C}_{3}\right), 26.8\left(\mathrm{C}_{t \mathrm{Bu}, \mathrm{Me}}\right), 19.2\left(\mathrm{C}_{t \mathrm{Bu}}\right.$,quat $) \mathrm{ppm} ;{ }^{19} \mathrm{~F}$ NMR $\left(376 \mathrm{MHz}, \mathrm{CDCl}_{3}\right) \delta-189.7$ (dquin, $\left.J=48.9,22.5, \mathrm{~F}_{2}\right) \mathrm{ppm} ;{ }^{19} \mathrm{~F}\left\{{ }^{1} \mathrm{H}\right\} \mathrm{NMR}\left(376 \mathrm{MHz}, \mathrm{CDCl}_{3}\right)$ $\delta-189.5\left(\mathrm{~s}, \mathrm{~F}_{2}\right) \mathrm{ppm} ; \mathrm{HRMS}(\mathrm{ESI}) \mathrm{m} / \mathrm{z}:[\mathrm{M}+\mathrm{Na}]^{+} \mathrm{Calcd}$ for $\mathrm{C}_{21} \mathrm{H}_{29} \mathrm{FNaO}_{3} \mathrm{Si}$ 399.1762; Found 399.1767.

The synthesis was repeated from $(\boldsymbol{R})-\mathbf{2 6}(25.0 \mathrm{~g}, 70.5 \mathrm{mmol})$ to give $(\mathbf{2 S}, \mathbf{4 R})-\mathbf{2 4}(9.54 \mathrm{~g}, 36 \%$ over 2 steps). Spectroscopic data was identical except $[\alpha]_{\mathrm{D}}{ }^{19}+2.1\left(\mathrm{c} 1.0, \mathrm{CHCl}_{3}\right)$.

1,6-Di- $O$-acetyl-2,3,4-trideoxy-2,4-fluoro-B-D-glucopyranose (27). Synthesized with a procedure of Zottola et al. ${ }^{72}$ To a solution of $44(431 \mathrm{mg}, 2.87 \mathrm{mmol}, 1.0)$ in $\mathrm{Ac}_{2} \mathrm{O}(70 \mathrm{~mL})$ at $0{ }^{\circ} \mathrm{C}$ was added TMSOTf $(0.104 \mathrm{~mL}, 0.570 \mathrm{mmol})$ dropwise. The resulting mixture was stirred at $0{ }^{\circ} \mathrm{C}$ for 30 min before being diluted with $\mathrm{CH}_{2} \mathrm{Cl}_{2}(20 \mathrm{~mL})$ and quenched with sat. aq. $\mathrm{NaHCO}_{3}(15 \mathrm{~mL})$. The aqueous layer was extracted with $\mathrm{CH}_{2} \mathrm{Cl}_{2}(3 \times 20 \mathrm{~mL})$ and the combined organic layers dried over anhydrous $\mathrm{MgSO}_{4}$ and concentrated in vacuo. The crude product was 
purified by flash column chromatography (hexane/acetone 90:10 to 80:20) to afford the title compound 27 as a light brown solid (682 mg, $2.70 \mathrm{mmol}, 94 \%)$. $\mathrm{R}_{\mathrm{f}} 0.23$ (hexane/acetone 80:20); IR 1760 (m), 1739 (s), 1245 (s), 1226 (s), 1124 (m), 1095 (m), 1052 (s), 1000 (s) cm ${ }^{1} ;{ }^{1} \mathrm{H}$ NMR (500 MHz, $\left.\mathrm{CDCl}_{3}, \alpha: \beta 2.20: 1.00\right) \delta 6.27\left(1 \mathrm{H}, \mathrm{t}, J=3.8 \mathrm{~Hz}, \mathrm{H}_{1} \alpha\right), 5.74(1 \mathrm{H}, \mathrm{dd}, J=$ 7.4, 3.6 Hz, $\left.\mathrm{H}_{1 \beta}\right), 4.66\left(1 \mathrm{H}\right.$, ddddd, $\left.J=46.6,12.0,5.2,3.7,1.5 \mathrm{~Hz}, \mathrm{H}_{2 \alpha}\right), 4.53(1 \mathrm{H}, \mathrm{ddd}, J=$ 48.4, 10.3, $\left.5.1 \mathrm{~Hz}, \mathrm{H}_{4 \beta}\right), 4.51\left(1 \mathrm{H}, \mathrm{dddd}, J=48.4,10.0,5.2,1.4 \mathrm{~Hz}, \mathrm{H}_{4 \alpha}\right), 4.45$ (1H, ddddd, $J$ $\left.=48.8,10.7,7.3,5.3,1.1 \mathrm{~Hz}, \mathrm{H}_{2 \beta}\right), 4.35\left(1 \mathrm{H}, \mathrm{ddd}, J=12.2,2.9,1.5 \mathrm{~Hz}, \mathrm{H}_{6 \beta}\right), 4.33(1 \mathrm{H}, \mathrm{dt}, J=$ 12.0, $\left.2.5 \mathrm{~Hz}, \mathrm{H}_{6 \alpha}\right), 4.23\left(1 \mathrm{H}, \mathrm{ddd}, J=12.4,4.9,1.5 \mathrm{~Hz}, \mathrm{H}_{6}{ }^{\circ} \alpha\right), 4.21(1 \mathrm{H}, \mathrm{ddd}, J=12.3,5.5,1.6$ Hz, $\left.\mathrm{H}_{6} \beta\right), 3.95\left(1 \mathrm{H}, \mathrm{dtt}, J=7.2,4.6,2.4 \mathrm{~Hz}, \mathrm{H}_{5 \alpha}\right), 3.87(1 \mathrm{H}$, dddd, $J=8.7,5.6,4.5,3.0 \mathrm{~Hz}$, $\left.\mathrm{H}_{5 \beta}\right), 2.77\left(1 \mathrm{H}, \mathrm{dtt}, J=12.7,7.8,5.2 \mathrm{~Hz}, \mathrm{H}_{3 \mathrm{eq} \beta}\right), 2.65\left(1 \mathrm{H}, \mathrm{dquin}, J=10.6,5.2 \mathrm{~Hz}, \mathrm{H}_{3 \mathrm{eq} \alpha}\right), 2.22$ $\left(1 \mathrm{H}, \mathrm{dqd}, J=23.0,11.4,9.4 \mathrm{~Hz}, \mathrm{H}_{3 \mathrm{ax} \alpha}\right), 2.19\left(3 \mathrm{H}, \mathrm{s}, \mathrm{H}_{\mathrm{Ac} \alpha}\right), 2.16\left(3 \mathrm{H}, \mathrm{s}, \mathrm{H}_{\mathrm{Ac} \beta}\right), 2.09$ (3H, s, $\left.\mathrm{H}_{\mathrm{Ac} \beta}\right), 2.09\left(3 \mathrm{H}, \mathrm{s}, \mathrm{H}_{\mathrm{Ac} \alpha}\right), 2.06\left(1 \mathrm{H}, \mathrm{dtdd}, J=22.9,12.4,10.5,10.4 \mathrm{~Hz}, \mathrm{H}_{3 \mathrm{ax} \beta}\right) \mathrm{ppm} ;{ }^{1} \mathrm{H}\left\{{ }^{19} \mathrm{~F}\right\}$ $\operatorname{NMR}\left(500 \mathrm{MHz}, \mathrm{CDCl}_{3}\right) \delta 6.27\left(1 \mathrm{H}, \mathrm{d}, J=3.6 \mathrm{~Hz}, \mathrm{H}_{1 \alpha}\right), 5.74\left(1 \mathrm{H}, \mathrm{d}, J=7.4 \mathrm{~Hz}, \mathrm{H}_{1 \beta}\right), 4.67$ $\left(1 \mathrm{H}, \mathrm{ddd}, J=12.0,5.1,3.7 \mathrm{~Hz}, \mathrm{H}_{2 \alpha}\right), 4.55-4.49\left(2 \mathrm{H}, \mathrm{m}, \mathrm{H}_{4 \alpha+4 \beta}\right), 4.45(1 \mathrm{H}, \mathrm{ddd}, J=10.7,7.3$, $\left.5.3 \mathrm{~Hz}, \mathrm{H}_{2 \beta}\right), 4.35\left(1 \mathrm{H}, \mathrm{dd}, J=12.2,2.9 \mathrm{~Hz}, \mathrm{H}_{6 \beta}\right), 4.33\left(1 \mathrm{H}, \mathrm{dd}, J=12.0,2.5 \mathrm{~Hz}, \mathrm{H}_{6 \alpha}\right), 4.23$ $\left(1 \mathrm{H}, \mathrm{dd}, J=12.3,4.9 \mathrm{~Hz}, \mathrm{H}_{6^{\prime}} \alpha\right), 4.21\left(1 \mathrm{H}, \mathrm{dd}, J=12.3,5.5 \mathrm{~Hz}, \mathrm{H}_{6}{ }^{\prime}\right), 3.95(1 \mathrm{H}, \mathrm{ddd}, J=9.7$, 4.9, $\left.2.4 \mathrm{~Hz}, \mathrm{H}_{5 \alpha}\right), 3.87\left(1 \mathrm{H}, \mathrm{ddd}, J=8.7,5.6,2.9 \mathrm{~Hz}, \mathrm{H}_{5 \beta}\right), 2.77\left(1 \mathrm{H}, \mathrm{dt}, J=12.3,5.2 \mathrm{~Hz}, \mathrm{H}_{3 \mathrm{eq} \beta}\right)$, $2.64\left(1 \mathrm{H}, \mathrm{dt}, J=11.2,5.1 \mathrm{~Hz}, \mathrm{H}_{3 \mathrm{eq} \alpha}\right), 2.24\left(1 \mathrm{H}, \mathrm{q}, J=11.4 \mathrm{~Hz}, \mathrm{H}_{3 \mathrm{ax} \alpha}\right), 2.19\left(3 \mathrm{H}, \mathrm{s}, \mathrm{H}_{\mathrm{Ac} \alpha}\right), 2.16$ $\left(3 \mathrm{H}, \mathrm{s}, \mathrm{H}_{\mathrm{Ac} \beta}\right), 2.09\left(3 \mathrm{H}, \mathrm{s}, \mathrm{H}_{\mathrm{Ac} \beta}\right), 2.09$ (3H, s, $\left.\mathrm{H}_{\mathrm{Ac} \alpha}\right), 2.05(1 \mathrm{H}, \mathrm{ddd}, J=12.3,10.5,10.4 \mathrm{~Hz}$, $\left.\mathrm{H}_{3 \mathrm{ax} \beta}\right) \mathrm{ppm} ;{ }^{13} \mathrm{C}\left\{{ }^{1} \mathrm{H}\right\} \mathrm{NMR}\left(126 \mathrm{MHz}, \mathrm{CDCl}_{3}\right), \delta 170.6\left(\mathrm{C}_{\mathrm{C}=\mathrm{O} \alpha}\right), 170.6\left(\mathrm{C}_{\mathrm{C}=\mathrm{O} \beta}\right), 168.9\left(\mathrm{C}_{\mathrm{C}=\mathrm{O} \beta}\right)$, $168.9\left(\mathrm{C}_{\mathrm{C}=\mathrm{O} \alpha}\right), 92.7\left(\mathrm{dd}, J_{\mathrm{C}-\mathrm{F}}=26.1,0.8 \mathrm{~Hz}, \mathrm{C}_{1 \beta}\right), 87.4\left(\mathrm{dd}, J_{\mathrm{C}-\mathrm{F}}=22.9,1.27 \mathrm{~Hz}, \mathrm{C}_{1} \alpha\right), 84.9(\mathrm{dd}$, $\left.J_{\mathrm{C}-\mathrm{F}}=185.5,10.5 \mathrm{~Hz}, \mathrm{C}_{2 \beta}\right), 83.6\left(\mathrm{dd}, J_{\mathrm{C}-\mathrm{F}}=189.5,12.2 \mathrm{~Hz}, \mathrm{C}_{2} \alpha\right), 83.4\left(\mathrm{dd}, J_{\mathrm{C}-\mathrm{F}}=182.4,10.0\right.$ $\left.\mathrm{Hz}, \mathrm{C}_{4 \beta}\right), 83.3\left(\mathrm{dd}, J_{\mathrm{C}-\mathrm{F}}=182.1,11.7 \mathrm{~Hz}, \mathrm{C}_{4 \alpha}\right), 75.3\left(\mathrm{dd}, J_{\mathrm{C}-\mathrm{F}}=25.0,0.9 \mathrm{~Hz}, \mathrm{C}_{5 \beta}\right), 69.8\left(\mathrm{dd}, J_{\mathrm{C}-}\right.$ $\left.\mathrm{F}=24.4,0.8 \mathrm{~Hz}, \mathrm{C}_{5 \alpha}\right), 62.1\left(\mathrm{~d}, J_{\mathrm{C}-\mathrm{F}}=1.0 \mathrm{~Hz}, \mathrm{C}_{6 \beta}\right), 61.9\left(\mathrm{C}_{6 \alpha}\right), 33.8\left(\mathrm{t}, J_{\mathrm{C}-\mathrm{F}}=20.5 \mathrm{~Hz}, \mathrm{C}_{3 \beta}\right), 30.9$

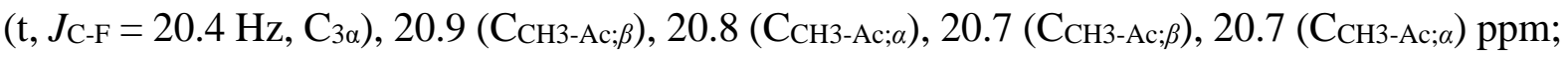


${ }^{19} \mathrm{~F}$ NMR (471 MHz, CDCl3) $\delta-188.5$ to -188.6 (m, dobs, $J=48.3 \mathrm{~Hz}, \mathrm{~F}_{4 \alpha}$ ), -189.9 to -190.0 (m, dobs, $J=48.3 \mathrm{~Hz}, \mathrm{~F}_{4 \beta}$ ), -191.0 to -191.2 (m, dobs, $J=48.6 \mathrm{~Hz}, \mathrm{~F}_{2 \beta}$ ), -192.4 (ddddd, $J=$ 46.5, 9.3, 4.7, 3.6, 1.4 Hz, F $2 \alpha) \mathrm{ppm} ;{ }^{19} \mathrm{~F}\left\{{ }^{1} \mathrm{H}\right\} \mathrm{NMR}\left(471 \mathrm{MHz}, \mathrm{CDCl}_{3}\right) \delta-188.6(\mathrm{~d}, J=3.6 \mathrm{~Hz}$, $\left.\mathrm{F}_{4 \alpha}\right),-189.9\left(\mathrm{~d}, J=5.0 \mathrm{~Hz}, \mathrm{~F}_{4 \beta}\right),-191.1\left(\mathrm{~d}, J=5.4 \mathrm{~Hz}, \mathrm{~F}_{2 \beta}\right),-192.4\left(\mathrm{~d}, J=3.6 \mathrm{~Hz}, \mathrm{~F}_{2 \alpha}\right) \mathrm{ppm}$; HRMS (ESI) m/z: $[\mathrm{M}+\mathrm{Na}]^{+}$Calcd for $\mathrm{C}_{10} \mathrm{H}_{14} \mathrm{~F}_{2} \mathrm{NaO}_{5}$ 275.0702; Found 275.0702.

5-(Benzyloxy)-4-fluoropentanal (30). To a solution of 47 (538 $\mathrm{mg}, 2.58 \mathrm{mmol})$ in a mixture of $\mathrm{MeCN}(22.1 \mathrm{~mL})$ and water $(3.7 \mathrm{~mL})$ at $\mathrm{rt}$ was added a solution of $\mathrm{RuCl}_{3}$ in water $(2.58 \mathrm{~mL}$, $0.035 \mathrm{M}, 0.090 \mathrm{mmol}) . \mathrm{NaIO}_{4}(1.11 \mathrm{~g}, 5.17 \mathrm{mmol})$ was added portionwise over $5 \mathrm{~min}$. The mixture was stirred for $24 \mathrm{~h}$, and quenched by slow addition of sat. aq. $\mathrm{Na}_{2} \mathrm{~S}_{2} \mathrm{O}_{3}(25 \mathrm{~mL})$. The aqueous phase was extracted with EtOAc $(3 \times 50 \mathrm{~mL})$, washed with sat. brine $(25 \mathrm{~mL})$, dried over $\mathrm{MgSO}_{4}$, and concentrated in vacuo. The crude product was purified by flash column chromatography (hexane/EtOAc 70:30) to afford the title compound $\mathbf{3 0}$ as a colourless oil (212 mg, 39\%). Rf 0.32 (hexane/EtOAc 70:30); IR 3657 (w), 2980 (s), 2889 (m), 1722 (s), 1382 (m), $1092(\mathrm{~s}) \mathrm{cm}^{-1} ;{ }^{1} \mathrm{H}$ NMR $\left(400 \mathrm{MHz}, \mathrm{CDCl}_{3}\right) \delta 9.81\left(1 \mathrm{H}, \mathrm{q}, J=1.0 \mathrm{~Hz}, \mathrm{H}_{1}\right), 7.39-7.29(5 \mathrm{H}$, m, HPh), 4.79-4.61 (1H, m, H4), $4.59\left(2 \mathrm{H}, \mathrm{s}, \mathrm{H}_{6}\right), 3.61\left(2 \mathrm{H}, \mathrm{dd}, J=22.7,4.5 \mathrm{~Hz}, \mathrm{H}_{5}\right), 2.72-2.57$ $\left(2 \mathrm{H}, \mathrm{m}, \mathrm{H}_{2}\right), 2.06-1.94\left(2 \mathrm{H}, \mathrm{m}, \mathrm{H}_{3}\right) \mathrm{ppm} ;{ }^{13} \mathrm{C}\left\{{ }^{1} \mathrm{H}\right\} \mathrm{NMR}\left(101 \mathrm{MHz}, \mathrm{CDCl}_{3}\right) \delta 201.1\left(\mathrm{C}_{1}\right), 137.7$ $\left(\mathrm{C}_{\mathrm{Ph}}\right), 128.5\left(\mathrm{C}_{\mathrm{Ph}}\right), 127.8\left(\mathrm{CPh}_{\mathrm{Ph}}\right), 127.7\left(\mathrm{CPh}_{\mathrm{Ph}}\right), 91.8\left(\mathrm{~d}, J_{\mathrm{C}-\mathrm{F}}=171.7 \mathrm{~Hz}, \mathrm{C}_{4}\right), 73.5\left(\mathrm{C}_{\mathrm{Bn}}\right), 71.5(\mathrm{~d}$, $\left.J_{\mathrm{C}-\mathrm{F}}=22.0 \mathrm{~Hz}, \mathrm{C}_{5}\right), 39.2\left(\mathrm{~d}, J_{\mathrm{C}-\mathrm{F}}=3.7 \mathrm{~Hz}, \mathrm{C}_{2}\right), 24.1\left(\mathrm{~d}, J_{\mathrm{C}-\mathrm{F}}=21.3 \mathrm{~Hz}, \mathrm{C}_{3}\right) \mathrm{ppm} ;{ }^{19} \mathrm{~F} \mathrm{NMR}(376$ $\left.\mathrm{MHz}, \mathrm{CDCl}_{3}\right) \delta-188.5$ to $-188.9\left(\mathrm{~m}, \mathrm{~F}_{4}\right) \mathrm{ppm} ;{ }^{19} \mathrm{~F}\left\{{ }^{1} \mathrm{H}\right\} \mathrm{NMR}\left(376 \mathrm{MHz}, \mathrm{CDCl}_{3}\right) \delta-188.8(\mathrm{~s}$, F4) ppm; HRMS (EI) m/z: [M] $]^{+}$Calcd for $\mathrm{C}_{12} \mathrm{H}_{15} \mathrm{FO}_{2} 210.1051$; Found 210.1052.

5-((tert-Butyldiphenylsilyl)oxy)-4,4-difluoropentanal (33). To a solution of ester $\mathbf{5 0}$ (4.80 g, $11.4 \mathrm{mmol})$ in $\mathrm{CH}_{2} \mathrm{Cl}_{2}(91 \mathrm{~mL})$ at $-78{ }^{\circ} \mathrm{C}$ was added DIBAL $\left(1 \mathrm{M}\right.$ in $\mathrm{CH}_{2} \mathrm{Cl}_{2}, 13.7 \mathrm{~mL}, 13.7$ mmol) slowly over $15 \mathrm{~min}$, keeping the internal temperature below $-60{ }^{\circ} \mathrm{C}$. The reaction was stirred for $3 \mathrm{~h}$ then quenched by slow addition of aq. Rochelle's salt (90 mL), allowed to warm to $\mathrm{rt}$, and stirred for a further $1 \mathrm{~h}$. The phases were separated and the aqueous layer extracted 
with $\mathrm{CH}_{2} \mathrm{Cl}_{2}(3 \times 100 \mathrm{~mL})$. The combined organic layers were dried over $\mathrm{MgSO}_{4}$ and concentrated in vacuo to afford the title compound $\mathbf{3 3}$ as a clear colourless oil (4.36 g, quant.). Rf 0.50 (hexane/EtOAc 70:30); IR 2932 (m), 2858 (m), 1726 (m), 1428 (m), 1106 (s) $\mathrm{cm}^{-1} ;{ }^{1} \mathrm{H}$ NMR (400 MHz, CDCl 3 ) $\delta 9.83\left(1 \mathrm{H}, \mathrm{s}, \mathrm{H}_{1}\right), 7.69-7.65$ (4H, m, HPh), 7.49-7.39 (6H, m, HPh), $3.77\left(2 \mathrm{H}, \mathrm{t}, J=12.0 \mathrm{~Hz}, \mathrm{H}_{5}\right), 2.69\left(2 \mathrm{H}, \mathrm{t}, J=7.5 \mathrm{~Hz}, \mathrm{H}_{2}\right), 2.35\left(2 \mathrm{H}, \mathrm{tt}, J=17.5,7.6 \mathrm{~Hz}, \mathrm{H}_{3}\right)$, $1.09\left(9 \mathrm{H}, \mathrm{s}, \mathrm{H}_{t \mathrm{Bu}}\right) \mathrm{ppm} ;{ }^{13} \mathrm{C}\left\{{ }^{1} \mathrm{H}\right\} \mathrm{NMR}\left(101 \mathrm{MHz}, \mathrm{CDCl}_{3}\right) \delta 200.1\left(\mathrm{C}_{1}\right), 135.6\left(\mathrm{CPh}_{\mathrm{Ph}}\right), 132.4$ $\left(\mathrm{CPh}_{\mathrm{Ph}}\right), 130.0\left(\mathrm{CPh}_{\mathrm{Ph}}\right), 127.8\left(\mathrm{CPh}_{\mathrm{Ph}}\right), 122.6\left(\mathrm{t}, J_{\mathrm{C}-\mathrm{F}}=242.8 \mathrm{~Hz}, \mathrm{C}_{4}\right), 65.1\left(\mathrm{t}, J_{\mathrm{C}-\mathrm{F}}=34.8 \mathrm{~Hz}, \mathrm{C}_{5}\right), 36.3$ $\left(\mathrm{t}, J_{\mathrm{C}-\mathrm{F}}=3.7 \mathrm{~Hz}, \mathrm{C}_{2}\right), 26.7\left(\mathrm{C}_{t \mathrm{Bu}, \mathrm{Me}}\right), 26.0\left(\mathrm{t}, J_{\mathrm{C}-\mathrm{F}}=24.9 \mathrm{~Hz}, \mathrm{C}_{3}\right), 19.2\left(\mathrm{C}_{t \mathrm{Bu}, \text { quat }}\right) \mathrm{ppm} ;{ }^{19} \mathrm{~F} \mathrm{NMR}$ $\left(376 \mathrm{MHz}, \mathrm{CDCl}_{3}\right) \delta-108.0\left(\mathrm{tt}, J=17.3,12.1 \mathrm{~Hz}, \mathrm{~F}_{4}\right) \mathrm{ppm} ;{ }^{19} \mathrm{~F}\left\{{ }^{1} \mathrm{H}\right\} \mathrm{NMR}\left(376 \mathrm{MHz}, \mathrm{CDCl}_{3}\right)$ $\delta-108.0(\mathrm{~s}, \mathrm{~F} 4)$ ppm; HRMS (ESI) m/z: [M + Na] $]^{+}$Calcd for $\mathrm{C}_{21} \mathrm{H}_{26} \mathrm{~F}_{2} \mathrm{NaO}_{2} \mathrm{Si}$ 399.1562; Found 399.1572.

\section{(2R,4S)-5-((tert-Butyldiphenylsilyl)oxy)-2-fluoro-4-hydroxypentanamide (38)}

Synthesized according to the procedure of Liotta et al. ${ }^{52}$ To a stirred solution of lactone $(\boldsymbol{S})$ $2^{54}$ (200 mg, $\left.0.564 \mathrm{mmol}\right)$ and NFSI $(178 \mathrm{mg}, 0.564 \mathrm{mmol})$ in THF $(2.5 \mathrm{~mL})$ at $-78{ }^{\circ} \mathrm{C}$, LiHMDS (1M in THF, $0.68 \mathrm{~mL}, 0.68 \mathrm{mmol}$ ) was added dropwise over $1 \mathrm{~h}$. The solution was stirred at $-78{ }^{\circ} \mathrm{C}$ for $2 \mathrm{~h}$ then warmed to $\mathrm{rt}$ and stirred for $1 \mathrm{~h}$. The reaction was quenched by cautious addition of sat. aq. $\mathrm{NH}_{4} \mathrm{Cl}(0.1 \mathrm{~mL})$ and then diluted with $\mathrm{Et}_{2} \mathrm{O}(7.5 \mathrm{~mL})$ and washed sequentially with sat. aq. $\mathrm{NaHCO}_{3}(2 \times 7.5 \mathrm{~mL})$ and sat. brine $(7.5 \mathrm{~mL})$, dried over $\mathrm{MgSO}_{4}$, and concentrated in vacuo. The residue was purified by flash column chromatography (hexane/EtOAc 90:10 to 0:100), to obtain $(\mathbf{2 R , 4 S ) - 2 5}(22 \mathrm{mg}, 10 \%)$ as a white solid, and the title compound 38 as a yellow oil (33 mg, 15\%). Rf 0.24 (hexane/EtOAc 40:60); IR 3323 (br. m), 3071 (w), 2930 (m), 2857 (m), 1679 (s), 1427 (m), 1105 (s) cm ${ }^{-1} ;{ }^{1} \mathrm{H}$ NMR (400 MHz, $\left.\mathrm{CDCl}_{3}\right) \delta$ 7.68-7.65 (4H, m, HPh), 7.47-7.38 (6H, m, HPh), $6.34\left(1 \mathrm{H}\right.$, br. s, $\left.\mathrm{NH}_{2}\right), 6.09$ (1H, br. s, $\left.\mathrm{NH}_{2}\right), 5.06\left(1 \mathrm{H}, \mathrm{dt}, J=49.2,6.2 \mathrm{~Hz}, \mathrm{H}_{2}\right), 4.07-4.00\left(1 \mathrm{H}, \mathrm{m}, \mathrm{H}_{4}\right), 3.69(1 \mathrm{H}, \mathrm{dd}, J=10.3,4.0$ Hz, H5), $3.60\left(1 \mathrm{H}, \mathrm{dd}, J=10.3,7.0 \mathrm{~Hz}, \mathrm{H}_{5}\right), 2.82(1 \mathrm{H}, \mathrm{d}, \mathrm{J}=4.8 \mathrm{~Hz}, \mathrm{OH}), 2.14(2 \mathrm{H}, \mathrm{dt}, J=$ 
24.5, $\left.6.2 \mathrm{~Hz}, \mathrm{H}_{3}\right), 1.08\left(9 \mathrm{H}, \mathrm{s}, \mathrm{H}_{t \mathrm{Bu}}\right) \mathrm{ppm} ;{ }^{13} \mathrm{C}\left\{{ }^{1} \mathrm{H}\right\} \mathrm{NMR}\left(101 \mathrm{MHz}, \mathrm{CDCl}_{3}\right) \delta 172.9\left(\mathrm{~d}, J_{\mathrm{C}-\mathrm{F}}=\right.$ $\left.20.5 \mathrm{~Hz}, \mathrm{C}_{1}\right), 135.5\left(\mathrm{CPh}_{\mathrm{Ph}}\right), 132.94\left(\mathrm{CPh}_{\mathrm{Ph}}\right), 132.91\left(\mathrm{CPh}_{\mathrm{Ph}}\right), 129.9\left(\mathrm{CPh}_{\mathrm{Ph}}\right), 127.8\left(\mathrm{CPh}_{\mathrm{Ph}}\right), 89.2\left(\mathrm{~d}, J_{\mathrm{C}-\mathrm{F}}=\right.$ 191.5 Hz, C2), $68.4\left(\mathrm{~d}, J_{\mathrm{C}-\mathrm{F}}=4.4 \mathrm{~Hz}, \mathrm{C}_{4}\right), 67.3\left(\mathrm{C}_{5}\right), 35.5\left(\mathrm{~d}, J_{\mathrm{C}-\mathrm{F}}=20.5 \mathrm{~Hz}, \mathrm{C}_{3}\right), 26.8\left(\mathrm{C}_{t \mathrm{Bu}, \mathrm{Me}}\right)$, $19.2\left(\mathrm{C}_{t \mathrm{Bu}, \text { quat }}\right) \mathrm{ppm} ;{ }^{19} \mathrm{~F} \mathrm{NMR}\left(376 \mathrm{MHz}, \mathrm{CDCl}_{3}\right) \delta-186.4\left(1 \mathrm{~F}, \mathrm{dtd}, J=49.2,24.5,3.5 \mathrm{~Hz}, \mathrm{~F}_{2}\right)$ ppm; ${ }^{19} \mathrm{~F}\left\{{ }^{1} \mathrm{H}\right\} \mathrm{NMR}\left(376 \mathrm{MHz}, \mathrm{CDCl}_{3}\right) \delta-186.3\left(1 \mathrm{~F}, \mathrm{~s}, \mathrm{~F}_{2}\right) \mathrm{ppm} ; \mathrm{HRMS}(\mathrm{ESI}) \mathrm{m} / \mathrm{z}:[\mathrm{M}+\mathrm{Na}]^{+}$ Calcd for $\mathrm{C}_{21} \mathrm{H}_{28} \mathrm{FNNaO}_{3} \mathrm{Si}$ 412.1715; Found 412.1716.

\section{$(2 R, 4 S)-5$-((tert-Butyldiphenylsilyl)oxy)-2-fluoro-4-hydroxypentyl benzoate $((2 R, 4 S)-39)$.}

To a solution of $(\mathbf{2} \boldsymbol{R}, \mathbf{4 S})-\mathbf{2 4}(0.900 \mathrm{~g}, 2.39 \mathrm{mmol})$ and $\mathrm{Et} 3 \mathrm{~N}(0.67 \mathrm{~mL}, 4.8 \mathrm{mmol})$ in $\mathrm{CH}_{2} \mathrm{Cl}_{2}$ $(12.0 \mathrm{~mL})$ at $0{ }^{\circ} \mathrm{C}$ was added benzoyl chloride $(0.28 \mathrm{~mL}, 2.4 \mathrm{mmol})$ dropwise over $5 \mathrm{~min}$. The mixture was warmed to $\mathrm{rt}$ and stirred for $16 \mathrm{~h}$, then diluted with $\mathrm{CH}_{2} \mathrm{Cl}_{2}(40 \mathrm{~mL})$. The organic layer was washed with water $(25 \mathrm{~mL})$, dried over $\mathrm{MgSO}_{4}$ and concentrated in vacuo. The crude product was purified by flash column chromatography (hexane/EtOAc 90:10 to 70:30) to afford the title compound $((\mathbf{2} \mathbf{R}, \mathbf{4 S})-39)$ as a yellow oil $(0.768 \mathrm{~g}, 67 \%)$. $\mathrm{R}_{\mathrm{f}} 0.29$ (hexane/EtOAc 70:30); $[\alpha]_{\mathrm{D}}{ }^{19}-11.6$ (c 0.5, $\mathrm{CHCl}_{3}$ ); IR 3656 (w), 2980 (s), 2889 (m), 1720 (m), 1270 (s), 1111 (s) $\mathrm{cm}^{-1} ;{ }^{1} \mathrm{H}$ NMR $\left(400 \mathrm{MHz}, \mathrm{CDCl}_{3}\right) \delta$ 8.09-8.06 (2H, m, Hph), 7.69-7.66 (4H, m, HPh), 7.59 $\left(1 \mathrm{H}, \mathrm{tt}, J=6.9,1.3 \mathrm{~Hz}, \mathrm{H}_{\mathrm{Ph}}\right), 7.48-7.38\left(8 \mathrm{H}, \mathrm{m}, \mathrm{H}_{\mathrm{Ph}}\right), 5.10-4.92\left(1 \mathrm{H}, \mathrm{m}, \mathrm{d}_{\mathrm{obs}}, J=48.3 \mathrm{~Hz}, \mathrm{H}_{2}\right)$, 4.58-4.42 (2H, m, $\left.\mathrm{H}_{1}\right), 4.02-3.95\left(1 \mathrm{H}, \mathrm{m}, \mathrm{H}_{4}\right), 3.72\left(1 \mathrm{H}, \mathrm{dd}, J=10.3,3.9 \mathrm{~Hz}, \mathrm{H}_{5}\right), 3.63(1 \mathrm{H}$, dd, $\left.J=10.3,7.1 \mathrm{~Hz}, \mathrm{H}_{5}{ }^{\prime}\right), 2.59(1 \mathrm{H}, \mathrm{d}, J=3.6 \mathrm{~Hz}, \mathrm{OH}), 2.06-1.83\left(2 \mathrm{H}, \mathrm{m}, \mathrm{H}_{3}\right), 1.09(9 \mathrm{H}, \mathrm{s}$, $\left.\mathrm{H}_{t \mathrm{Bu}}\right) \operatorname{ppm} ;{ }^{13} \mathrm{C}\left\{{ }^{1} \mathrm{H}\right\} \mathrm{NMR}\left(101 \mathrm{MHz}, \mathrm{CDCl}_{3}\right) \delta 166.2\left(\mathrm{C}_{\mathrm{C}=\mathrm{O}}\right), 135.5\left(\mathrm{C}_{\mathrm{Ph}}\right), 133.2\left(\mathrm{CPh}_{\mathrm{Ph}}\right), 132.91$ $(\mathrm{CPh}), 132.89(\mathrm{CPh}), 129.9(\mathrm{CPh}), 129.72(\mathrm{CPh}), 129.69(\mathrm{CPh}), 128.4(\mathrm{CPh}), 127.8(\mathrm{CPh}), 89.3(\mathrm{~d}$, $\left.J_{\mathrm{C}-\mathrm{F}}=171.7 \mathrm{~Hz}, \mathrm{C}_{2}\right), 68.6\left(\mathrm{~d}, J_{\mathrm{C}-\mathrm{F}}=5.1 \mathrm{~Hz}, \mathrm{C}_{4}\right), 67.4\left(\mathrm{C}_{5}\right), 65.9\left(\mathrm{~d}, J_{\mathrm{C}-\mathrm{F}}=22.0 \mathrm{~Hz}, \mathrm{C}_{1}\right), 34.5$ $\left(\mathrm{d}, J_{\mathrm{C}-\mathrm{F}}=20.5 \mathrm{~Hz}, \mathrm{C}_{3}\right), 26.8\left(\mathrm{C}_{t \mathrm{Bu}, \mathrm{Me}}\right), 19.2\left(\mathrm{C}_{t \mathrm{Bu} \text {,quat }}\right) \mathrm{ppm} ;{ }^{19} \mathrm{~F}$ NMR $\left(376 \mathrm{MHz}, \mathrm{CDCl}_{3}\right) \delta$ $-186.6\left(\mathrm{dqd}, J=49.0,24.4,18.2 \mathrm{~Hz}, \mathrm{~F}_{2}\right) \mathrm{ppm} ;{ }^{19} \mathrm{~F}\left\{{ }^{1} \mathrm{H}\right\} \mathrm{NMR}\left(376 \mathrm{MHz}, \mathrm{CDCl}_{3}\right) \delta-186.4(\mathrm{~s}$, $\left.\mathrm{F}_{2}\right)$ ppm; HRMS (ESI) m/z: [M + Na $]^{+}$Calcd for $\mathrm{C}_{28} \mathrm{H}_{33} \mathrm{FNaO}_{4} \mathrm{Si}$ 503.2024; Found 503.2029. 
The synthesis was repeated from $(\mathbf{2 S , 4 R})-\mathbf{2 4}(9.53 \mathrm{~g}, 25.3 \mathrm{mmol})$ to give $(\mathbf{2 S , 4 R})-39(9.14 \mathrm{~g}$, 75\%). Spectroscopic data was identical except $[\alpha]_{\mathrm{D}}{ }^{19}+10.2$ (c 1.0, $\left.\mathrm{CHCl}_{3}\right)$.

$(2 R, 4 R)-5-((t e r t-B u t y l d i p h e n y l s i l y l) o x y)-2,4-d i f l u o r o p e n t y l ~ b e n z o a t e ~((2 R, 4 R)-40)$. To a stirred solution of $(\mathbf{2 R}, \mathbf{4 S})-\mathbf{3 9}(584 \mathrm{mg}, 1.22 \mathrm{mmol})$ in dry $\mathrm{CH}_{2} \mathrm{Cl}_{2}(12.2 \mathrm{~mL})$ at $0{ }^{\circ} \mathrm{C}$ was added DAST $(0.32 \mathrm{~mL}, 2.44 \mathrm{mmol})$ dropwise. The solution was stirred at $0{ }^{\circ} \mathrm{C}$ for $1 \mathrm{~h}$ and then quenched by cautious addition of sat. aq. $\mathrm{NaHCO}_{3}(36 \mathrm{~mL})$. The layers were separated and the aqueous layer extracted with EtOAc $(3 \times 60 \mathrm{~mL})$. The combined organic layers were washed with sat. brine (36 mL), dried over $\mathrm{MgSO}_{4}$, and concentrated in vacuo. The crude product was purified by flash column chromatography (hexane/EtOAc 100:0 to 70:30) to afford the title compound $(\mathbf{2} \boldsymbol{R}, \mathbf{4 R})-\mathbf{4 0}$ as a yellow oil $(430 \mathrm{mg})$ containing an unknown impurity, which was taken forward in the next step. An aliquot was further purified by flash column chromatography (Biotage Isolera One, ZIP KP-SIL 5 g Column, hexane/acetone 100:0 to 70:30) for analysis. Rf 0.49 (hexane/EtOAc 70:30); $[\alpha]_{D}{ }^{26}+9.9$ (c 1.2, $\mathrm{CHCl}_{3}$, purified sample); IR 3071 (w), 2932

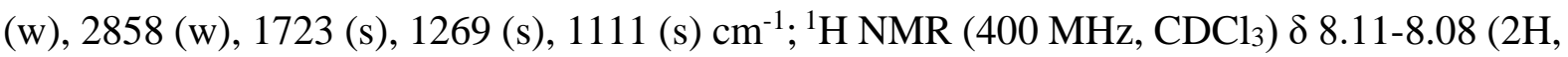
m, HPh), 7.71-7.67 (4H, m, HPh), 7.60 (1H, tt, $\left.J=7.5,1.3 \mathrm{~Hz}, \mathrm{HPh}_{\mathrm{Ph}}\right), 7.49-7.38\left(10 \mathrm{H}, \mathrm{m}, \mathrm{HPh}_{\mathrm{Ph}}\right.$, $5.11\left(1 \mathrm{H}\right.$, dddt, $\left.J=49.3,9.1,6.0,2.9 \mathrm{~Hz}, \mathrm{H}_{2}\right), 4.94-4.77\left(1 \mathrm{H}, \mathrm{m}, \mathrm{d}_{\mathrm{obs}}, J=48.7 \mathrm{~Hz}, \mathrm{H}_{4}\right), 4.56$ $\left(1 \mathrm{H}, \mathrm{ddd}, J=24.0,12.0,2.9 \mathrm{~Hz}, \mathrm{H}_{1}\right), 4.47\left(1 \mathrm{H}, \mathrm{ddd}, J=23.7,12.6,5.5 \mathrm{~Hz}, \mathrm{H}_{1}{ }^{\prime}\right), 3.88(1 \mathrm{H}, \mathrm{ddd}$, $\left.J=19.7,11.6,3.7 \mathrm{~Hz}, \mathrm{H}_{5}\right), 3.78\left(1 \mathrm{H}, \mathrm{ddd}, J=25.1,11.6,4.3 \mathrm{~Hz}, \mathrm{H}_{5}{ }^{\prime}\right), 2.22-1.96\left(2 \mathrm{H}, \mathrm{m}, \mathrm{H}_{3}\right)$, $1.08\left(9 \mathrm{H}, \mathrm{s}, \mathrm{H}_{t \mathrm{Bu}}\right) \mathrm{ppm} ;{ }^{13} \mathrm{C}\left\{{ }^{1} \mathrm{H}\right\} \mathrm{NMR}\left(101 \mathrm{MHz}, \mathrm{CDCl}_{3}\right) \delta 166.1\left(\mathrm{C}_{\mathrm{C}=\mathrm{O}}\right), 135.6\left(\mathrm{C}_{\mathrm{Ph}}\right), 135.5$ $(\mathrm{CPh}), 133.3(\mathrm{CPh}), 133.03(\mathrm{CPh}), 132.96(\mathrm{CPh}), 129.8(\mathrm{CPh}), 129.7(\mathrm{CPh}), 129.6(\mathrm{CPh}), 128.4$ $(\mathrm{CPh}), 127.8\left(\mathrm{CPh}_{\mathrm{Ph}}, 89.6\left(\mathrm{dd}, J_{\mathrm{C}-\mathrm{F}}=173.1,3.7 \mathrm{~Hz}, \mathrm{C}_{4}\right), 87.7\left(\mathrm{dd}, J_{\mathrm{C}-\mathrm{F}}=173.1,3.7 \mathrm{~Hz}, \mathrm{C}_{2}\right), 66.1\right.$ $\left(\mathrm{d}, J_{\mathrm{C}-\mathrm{F}}=22.0 \mathrm{~Hz}, \mathrm{C}_{1}\right), 65.6\left(\mathrm{~d}, J_{\mathrm{C}-\mathrm{F}}=23.5 \mathrm{~Hz}, \mathrm{C}_{5}\right), 33.7\left(\mathrm{t}, J_{\mathrm{C}-\mathrm{F}}=20.9 \mathrm{~Hz}, \mathrm{C}_{3}\right), 26.7\left(\mathrm{C}_{t \mathrm{Bu}, \mathrm{Me}}\right)$, $19.3\left(\mathrm{C}_{t \mathrm{Bu}, \text { quat }}\right) \mathrm{ppm} ;{ }^{19} \mathrm{~F} \mathrm{NMR}\left(376 \mathrm{MHz}, \mathrm{CDCl}_{3}\right) \delta-189.9$ to $-190.2\left(\mathrm{~m}, \mathrm{~F}_{2}\right),-190.7$ to -191.1 $\left(\mathrm{m}, \mathrm{F}_{4}\right) \mathrm{ppm} ;{ }^{19} \mathrm{~F}\left\{{ }^{1} \mathrm{H}\right\}$ NMR $\left(376 \mathrm{MHz}, \mathrm{CDCl}_{3}\right) \delta-190.1\left(\mathrm{~s}, \mathrm{~F}_{2}\right),-190.9\left(\mathrm{~s}, \mathrm{~F}_{4}\right)$ ppm; HRMS (ESI) $\mathrm{m} / \mathrm{z}:[\mathrm{M}+\mathrm{Na}]^{+}$Calcd for $\mathrm{C}_{28} \mathrm{H}_{32} \mathrm{~F}_{2} \mathrm{NaO}_{3} \mathrm{Si}$ 505.1981; Found 505.1992. 
The synthesis was repeated from $(\mathbf{2 S , 4 R})-39(9.13 \mathrm{~g}, 19.0 \mathrm{mmol})$ to give $(\mathbf{2 S , 4 S})-\mathbf{4 0}(7.32 \mathrm{~g})$ containing an unknown impurity, which was taken forward in the next step. Spectroscopic data was identical except $[\alpha]_{\mathrm{D}}^{27}-10.4\left(\mathrm{c} 0.5, \mathrm{CHCl}_{3}\right.$, purified sample).

$(2 R, 4 R)-2,4-D i f l u o r o-5-h y d r o x y p e n t y l ~ b e n z o a t e ~((2 R, 4 R)-41)$. To a stirred solution of $(\mathbf{2} \boldsymbol{R}, \mathbf{4 R})-\mathbf{4 0}(500 \mathrm{mg})$ in dry $\mathrm{THF}(10 \mathrm{~mL})$ at $0{ }^{\circ} \mathrm{C}$ was added TBAF $(1 \mathrm{M}$ in $\mathrm{THF}, 1.25 \mathrm{~mL}$, $1.25 \mathrm{mmol})$ dropwise. The mixture was stirred at $\mathrm{rt}$ for $2 \mathrm{~h}$, before sat. aq. $\mathrm{NH}_{4} \mathrm{Cl}(10 \mathrm{~mL})$ was added and the mixture stirred vigorously for $30 \mathrm{~min}$. The layers were separated and the aqueous layer extracted with EtOAc $(3 \times 10 \mathrm{~mL})$. The combined organic layers were washed with sat. brine (10 mL), dried over $\mathrm{MgSO}_{4}$, and concentrated in vacuo. The crude product was purified by flash column chromatography (hexane/EtOAc 90:10 to 60:40) to afford the title compound $(\mathbf{R}, \mathbf{4 R})-\mathbf{4 1}$ as a yellow solid (195 mg, 56\% over 2 steps). $\mathrm{R}_{\mathrm{f}} 0.14$ (hexane/EtOAc 70:30); $[\alpha]_{\mathrm{D}}{ }^{26}$ +11.1 (c 1.0, $\left.\mathrm{CHCl}_{3}\right) ; \mathrm{mp} 51-53{ }^{\circ} \mathrm{C}\left(\mathrm{CH}_{2} \mathrm{Cl}_{2}\right)$; IR 3328 (br. m), 2971 (m), 1727 (m), 1710 (s), $1284(\mathrm{~s}) \mathrm{cm}^{-1} ;{ }^{1} \mathrm{H}$ NMR $\left(400 \mathrm{MHz}, \mathrm{CDCl}_{3}\right) \delta 8.07(2 \mathrm{H}, \mathrm{d}, J=7.1 \mathrm{~Hz}, \mathrm{HPh}), 7.59(1 \mathrm{H}, \mathrm{t}, J=7.5$ Hz, Hph), $7.46(2 \mathrm{H}, \mathrm{t}, J=8.2 \mathrm{~Hz}, \mathrm{Hph}), 5.07$ (1H, dddt, $\left.J=48.9,9.9,5.6,2.8 \mathrm{~Hz}, \mathrm{H}_{2}\right), 4.87(1 \mathrm{H}$, dddt, $\left.J=49.3,9.9,5.6,2.9 \mathrm{~Hz}, \mathrm{H}_{4}\right), 4.54\left(1 \mathrm{H}, \mathrm{ddd}, J=24.1,12.8,2.9 \mathrm{~Hz}, \mathrm{H}_{1}\right), 4.44(1 \mathrm{H}$, ddd, $\left.J=23.8,12.6,5.9 \mathrm{~Hz}, \mathrm{H}_{1}{ }^{\prime}\right), 3.87\left(1 \mathrm{H}, \mathrm{ddd}, J=24.3,12.5,2.3 \mathrm{~Hz}, \mathrm{H}_{5}\right), 3.71(1 \mathrm{H}, \mathrm{ddd}, J=25.1$, 12.1, $5.9 \mathrm{~Hz}, \mathrm{H}_{5}$ ), 2.26 (1H, br. s, OH), 2.18-1.90 (2H, m, $\left.\mathrm{H}_{3}\right) \mathrm{ppm} ;{ }^{13} \mathrm{C}\left\{{ }^{1} \mathrm{H}\right\} \mathrm{NMR}(101 \mathrm{MHz}$, $\left.\mathrm{CDCl}_{3}\right) \delta 166.2\left(\mathrm{C}_{\mathrm{C}=\mathrm{O}}\right), 133.3\left(\mathrm{CPh}_{\mathrm{Ph}}\right), 129.7\left(\mathrm{CPh}_{\mathrm{Ph}}\right), 129.5\left(\mathrm{CPh}_{\mathrm{Ph}}\right), 128.4\left(\mathrm{CPh}_{\mathrm{Ph}}\right), 90.2\left(\mathrm{dd}, J_{\mathrm{C}-\mathrm{F}}=\right.$ $\left.169.8,2.6 \mathrm{~Hz}, \mathrm{C}_{4}\right), 87.6\left(\mathrm{dd}, J_{\mathrm{C}-\mathrm{F}}=173.5,3.3 \mathrm{~Hz}, \mathrm{C}_{2}\right), 66.0\left(\mathrm{~d}, J_{\mathrm{C}-\mathrm{F}}=22.0 \mathrm{~Hz}, \mathrm{C}_{1}\right), 64.7\left(\mathrm{~d}, J_{\mathrm{C}-}\right.$ $\left.\mathrm{F}=21.3 \mathrm{~Hz}, \mathrm{C}_{5}\right), 33.2\left(\mathrm{t}, J_{\mathrm{C}-\mathrm{F}}=20.9 \mathrm{~Hz}, \mathrm{C}_{3}\right) \mathrm{ppm} ;{ }^{19} \mathrm{~F} \mathrm{NMR}\left(376 \mathrm{MHz}, \mathrm{CDCl}_{3}\right) \delta-189.8$ to $-190.2\left(\mathrm{~m}, \mathrm{~F}_{2}\right),-192.7$ to $-193.1(\mathrm{~m}, \mathrm{~F} 4) \mathrm{ppm} ;{ }^{19} \mathrm{~F}\left\{{ }^{1} \mathrm{H}\right\}$ NMR $\left(376 \mathrm{MHz}, \mathrm{CDCl}_{3}\right) \delta-189.9(\mathrm{~s}$, $\left.\mathrm{F}_{2}\right),-192.8\left(\mathrm{~s}, \mathrm{~F}_{4}\right) \mathrm{ppm}$; HRMS (ESI) $\mathrm{m} / \mathrm{z}:[\mathrm{M}+\mathrm{Na}]^{+}$Calcd for $\mathrm{C}_{12} \mathrm{H}_{14} \mathrm{~F}_{2} \mathrm{NaO}_{3}$ 267.0803; Found 267.0796.

The synthesis was repeated from $(\mathbf{2 S , 4 S})-\mathbf{4 0}(7.18 \mathrm{~g})$ to give $(\mathbf{2 S , 4 S})-\mathbf{4 1}(2.71 \mathrm{~g}, 61 \%$ over 2 steps). Spectroscopic data was identical except $[\alpha]_{\mathrm{D}}^{20}-10.0\left(\mathrm{c} 1.0, \mathrm{CHCl}_{3}\right)$. 


\section{1,6-Anhydro-2,4-dideoxy-2,4-difluoro-3- $O$-phenylthionoformyl- $\beta$-D-glucopyranoside}

(43). To a solution of $\mathbf{2 8}^{56,57}$ (1.92 $\left.\mathrm{g}, 11.6 \mathrm{mmol}\right)$ in $\mathrm{CH}_{2} \mathrm{Cl}_{2}(54 \mathrm{~mL})$ was added pyridine (1.87 $\mathrm{mL}, 23.1 \mathrm{mmol})$. The mixture was cooled to $0{ }^{\circ} \mathrm{C}$ and $O$-phenyl chorothionoformate $(1.92 \mathrm{~mL}$, $13.9 \mathrm{mmol}$ ) was added dropwise. The solution was stirred at $\mathrm{rt}$ for $24 \mathrm{~h}$. The reaction mixture was diluted with $\mathrm{CH}_{2} \mathrm{Cl}_{2}(50 \mathrm{~mL})$ and quenched with sat. aq. $\mathrm{NaHCO}_{3}(100 \mathrm{~mL})$. The aqueous layer was extracted with $\mathrm{CH}_{2} \mathrm{Cl}_{2}(3 \times 100 \mathrm{~mL})$ and the combined organic layers dried over $\mathrm{MgSO}_{4}$ and concentrated in vacuo. The crude product was purified by flash column chromatography (hexane/EtOAc 90:10 to 80:20) to afford the title compound $\mathbf{4 3}$ as an offwhite solid (3.33 g, 95\%). Rf 0.26 (petroleum ether/EtOAc 90:10); $[\alpha]_{\mathrm{D}}^{30}-54.5\left(\mathrm{c} 1.0, \mathrm{CHCl}_{3}\right)$; mp 104-108 ${ }^{\circ} \mathrm{C}$ (not recrystallized); IR 2973 (br. w), 2906 (w), 1274 (s), 1207 (s), 1057 (s) cm 1, ${ }^{1} \mathrm{H}$ NMR (500 MHz, $\left.\mathrm{CDCl}_{3}\right) \delta$ 7.48-7.43 (2H, m, $\left.\mathrm{H}_{\text {meta }}\right), 7.34\left(1 \mathrm{H}, \mathrm{tt}, J=7.5,1.1 \mathrm{~Hz}, \mathrm{H}_{\text {para }}\right)$, 7.15-7.11 (2H, m, $\left.\mathrm{H}_{\text {ortho }}\right)$, 5.68-5.66 (1H, m, $\left.\mathrm{H}_{1}\right), 5.63\left(1 \mathrm{H}\right.$, tquin, $\left.J=16.0,1.5 \mathrm{~Hz}, \mathrm{H}_{3}\right), 4.87-$ $4.84\left(1 \mathrm{H}, \mathrm{m}, \mathrm{H}_{5}\right), 4.65-4.56\left(1 \mathrm{H}, \mathrm{m}, \mathrm{d}_{\mathrm{obs}}, J=43.7 \mathrm{~Hz}, \mathrm{H}_{4}\right), 4.0\left(1 \mathrm{H}, \mathrm{dq}, J=44.3,1.1 \mathrm{~Hz}, \mathrm{H}_{2}\right)$, $4.01\left(1 \mathrm{H}, \mathrm{dt}, J=8.1,1.1 \mathrm{~Hz}, \mathrm{H}_{6 \mathrm{endo}}\right), 3.89-3.85\left(1 \mathrm{H}, \mathrm{m}, \mathrm{H}_{6 \mathrm{exo}}\right) \mathrm{ppm} ;{ }^{1} \mathrm{H}\left\{{ }^{19} \mathrm{~F}\right\} \mathrm{NMR}(500 \mathrm{MHz}$, $\left.\mathrm{CDCl}_{3}\right) \delta$ 7.48-7.43 $\left(2 \mathrm{H}, \mathrm{m}, \mathrm{H}_{\text {meta }}\right), 7.34\left(1 \mathrm{H}, \mathrm{tt}, J=7.5,1.1 \mathrm{~Hz}, \mathrm{H}_{\text {para }}\right), 7.14-7.11(2 \mathrm{H}, \mathrm{m}$, $\left.\mathrm{H}_{\text {ortho }}\right), 5.67\left(1 \mathrm{H}\right.$, br. $\left.\mathrm{t}, J=1.4 \mathrm{~Hz}, \mathrm{H}_{1}\right), 5.63\left(1 \mathrm{H}\right.$, quin, $\left.J=1.5 \mathrm{~Hz}, \mathrm{H}_{3}\right), 4.85(1 \mathrm{H}, \mathrm{dq}, J=6.0$, $\left.1.7 \mathrm{~Hz}, \mathrm{H}_{5}\right), 4.61-4.61\left(1 \mathrm{H}, \mathrm{m}, \mathrm{H}_{4}\right), 4.51-4.50\left(1 \mathrm{H}, \mathrm{m}, \mathrm{H}_{2}\right), 4.01$ (1H, dd, $\left.J=8.1,1.1 \mathrm{~Hz}, \mathrm{H}_{6 e n d o}\right)$, $3.87\left(1 \mathrm{H}, \mathrm{dd}, J=8.1,5.9 \mathrm{~Hz}, \mathrm{H}_{6 \mathrm{exo}}\right) \mathrm{ppm} ;{ }^{13} \mathrm{C}\left\{{ }^{1} \mathrm{H}\right\} \mathrm{NMR}\left(126 \mathrm{MHz}, \mathrm{CDCl}_{3}\right) \delta 193.1\left(\mathrm{C}_{\mathrm{C}=\mathrm{s}}\right)$, $153.3\left(\mathrm{C}_{\text {ipso }}\right), 129.8\left(\mathrm{C}_{\text {meta }}\right), 127.0\left(\mathrm{C}_{\text {para }}\right), 121.6\left(\mathrm{C}_{\text {ortho }}\right), 98.4\left(\mathrm{~d}, J_{\mathrm{C}-\mathrm{F}}=27.9 \mathrm{~Hz}, \mathrm{C}_{1}\right), 86.1(\mathrm{dd}$, $\left.J_{\mathrm{C}-\mathrm{F}}=183.4,2.9 \mathrm{~Hz}, \mathrm{C}_{4}\right), 83.9\left(\mathrm{dd}, J_{\mathrm{C}-\mathrm{F}}=185.2,1.8 \mathrm{~Hz}, \mathrm{C}_{2}\right), 76.6\left(\mathrm{dd}, J_{\mathrm{C}-\mathrm{F}}=35.8,34.1 \mathrm{~Hz}\right.$ $\left.\mathrm{C}_{3}\right), 73.5\left(\mathrm{~d}, J_{\mathrm{C}-\mathrm{F}}=21.3 \mathrm{~Hz}, \mathrm{C}_{5}\right), 63.9\left(\mathrm{~d}, J_{\mathrm{C}-\mathrm{F}}=8.8 \mathrm{~Hz}, \mathrm{C}_{6}\right) \mathrm{ppm} ;{ }^{19} \mathrm{~F}$ NMR $\left(471 \mathrm{MHz}, \mathrm{CDCl}_{3}\right)$ $\delta-184.2$ (ddddd, $\left.J=44.3,16.1,10.4,5.0,1.4 \mathrm{~Hz}, \mathrm{~F}_{4}\right),-189.8(\mathrm{dddd}, J=44.4,16.1,2.1,1.1$ $\left.\mathrm{Hz}, \mathrm{F}_{2}\right) \mathrm{ppm} ;{ }^{19} \mathrm{~F}\left\{{ }^{1} \mathrm{H}\right\} \mathrm{NMR}\left(471 \mathrm{MHz}, \mathrm{CDCl}_{3}\right) \delta-184.2\left(\mathrm{~s}, \mathrm{~F}_{4}\right),-189.8\left(\mathrm{~s}, \mathrm{~F}_{2}\right) \mathrm{ppm} ; \mathrm{HRMS}$ (ESI) $\mathrm{m} / \mathrm{z}:[\mathrm{M}+\mathrm{Na}]^{+}$Calcd for $\mathrm{C}_{13} \mathrm{H}_{12} \mathrm{~F}_{2} \mathrm{NaO}_{4} \mathrm{~S}$ 325.0317; Found 325.0316. 
1,6-Anhydro-2,3,4-trideoxy-2,4-difluoro- $\beta$-D-glucopyranose (44). Synthesized with a procedure of Kirwan et al. ${ }^{65}$ To a solution of $\mathbf{4 3}(3.18 \mathrm{~g}, 10.5 \mathrm{mmol})$ in triethylsilane $(79.0 \mathrm{~mL}$, $494 \mathrm{mmol}$ ) was added benzoyl peroxide $(509 \mathrm{mg}, 2.10 \mathrm{mmol})$. The resulting mixture was heated to $120{ }^{\circ} \mathrm{C}$ for $1 \mathrm{~h}$. The reaction was cooled to $\mathrm{rt}$, a further aliquot of benzoyl peroxide (509 $\mathrm{mg}, 2.10 \mathrm{mmol}$ ) was added, and the reaction reheated to $120^{\circ} \mathrm{C}$ for $1 \mathrm{~h}$. This was repeated a further 3 times (5 additions in total). The mixture was concentrated in vacuo and diluted with sat. aq. $\mathrm{NaHCO}_{3}(75 \mathrm{~mL})$ and $\mathrm{CH}_{2} \mathrm{Cl}_{2}(150 \mathrm{~mL})$. The organic layer was washed with sat. aq. $\mathrm{NaHCO}_{3}(3 \times 50 \mathrm{~mL})$, dried over $\mathrm{MgSO}_{4}$, and concentrated in vacuo. The crude product was purified by flash column chromatography (hexane/Et $2 \mathrm{O} 90: 10$ to 60:40) to afford the title compound 44 as a white powder with a $5 \%$ impurity of benzoic acid by mass $(1.32 \mathrm{~g}, 8.35$ mmol, $80 \%$ calculated for the pure compound). An aliquot was dissolved in $\mathrm{CH}_{2} \mathrm{Cl}_{2}$, washed three times with sat. $\mathrm{NaHCO}_{3}$, dried over $\mathrm{MgSO}_{4}$, and concentrated in vacuo for analysis. $\mathrm{R}_{\mathrm{f}}$ $0.55\left(\mathrm{Et}_{2} \mathrm{O} /\right.$ hexane $\left.70: 30\right) ;[\alpha]_{\mathrm{D}}{ }^{27}-75.6\left(\mathrm{c} 0.69, \mathrm{CHCl}_{3}\right) ; \mathrm{mp} 105-109{ }^{\circ} \mathrm{C}$ (not recrystallized); IR 2985 (w), 2910 (w), 2371 (w), 2353 (w), 1145 (m), 1064 (s) cm ${ }^{-1} ;{ }^{1} \mathrm{H}$ NMR (400 MHz, $\left.\mathrm{CDCl}_{3}\right) \delta 5.56\left(1 \mathrm{H}\right.$, br. s, $\left.\mathrm{H}_{1}\right), 4.76\left(1 \mathrm{H}, \mathrm{ddt}, J=7.8,5.6,2.7 \mathrm{~Hz}, \mathrm{H}_{5}\right), 4.58-4.32\left(2 \mathrm{H}, \mathrm{m}, \mathrm{H}_{2+4}\right)$, $3.85\left(1 \mathrm{H}, \mathrm{dtd}, J=7.9,5.3,2.6 \mathrm{~Hz}, \mathrm{H}_{6 \mathrm{exo}}\right), 3.75$ (1H, dt, $\left.J=8.1,1.2 \mathrm{~Hz}, \mathrm{H}_{6 \mathrm{endo}}\right), 2.34-2.01$ (2H, m, $\left.\mathrm{H}_{3 \mathrm{eq}+3 \mathrm{ax}}\right) \mathrm{ppm} ;{ }^{13} \mathrm{C}\left\{{ }^{1} \mathrm{H}\right\} \mathrm{NMR}\left(101 \mathrm{MHz}, \mathrm{CDCl}_{3}\right) \delta 99.1\left(\mathrm{~d}, J_{\mathrm{C}-\mathrm{F}}=25.7 \mathrm{~Hz}, \mathrm{C}_{1}\right), 84.9(\mathrm{dd}$, $\left.J_{\mathrm{C}-\mathrm{F}}=181.9,1.5 \mathrm{~Hz}, \mathrm{C}_{4}\right), 83.3\left(\mathrm{dd}, J_{\mathrm{C}-\mathrm{F}}=181.2,1.5 \mathrm{~Hz}, \mathrm{C}_{2}\right), 74.5\left(\mathrm{~d}, J_{\mathrm{C}-\mathrm{F}}=19.8 \mathrm{~Hz}, \mathrm{C}_{5}\right), 64.1$ $\left(\mathrm{d}, J_{\mathrm{C}-\mathrm{F}}=7.3 \mathrm{~Hz}, \mathrm{C}_{6}\right), 27.6\left(\mathrm{t}, J_{\mathrm{C}-\mathrm{F}}=22.4 \mathrm{~Hz}, \mathrm{C}_{3}\right) \mathrm{ppm} ;{ }^{19} \mathrm{~F} \mathrm{NMR}\left(376 \mathrm{MHz}, \mathrm{CDCl}_{3}\right) \delta-180.6$ to $-181.0\left(\mathrm{~m}, \mathrm{~F}_{4}\right),-186.0$ to $-186.3\left(\mathrm{~m}, \mathrm{~F}_{2}\right) \mathrm{ppm} ;{ }^{19} \mathrm{~F}\left\{{ }^{1} \mathrm{H}\right\} \mathrm{NMR}\left(376 \mathrm{MHz}, \mathrm{CDCl}_{3}\right) \delta-180.7$ $\left(\mathrm{d}, J=5.2 \mathrm{~Hz}, \mathrm{~F}_{4}\right),-186.0\left(\mathrm{~d}, J=3.5 \mathrm{~Hz}, \mathrm{~F}_{2}\right) \mathrm{ppm}$; HRMS (ESI) m/z: [M + Na $]^{+}$Calcd for $\mathrm{C}_{6} \mathrm{H}_{8} \mathrm{~F}_{2} \mathrm{NaO}_{2}$ 173.0385; Found 173.0390.

(2R,3S,5R)-3,5-Difluorohexane-1,2,6-triol (45). To a solution of 27 (495 mg, $1.96 \mathrm{mmol}$ ) in $\mathrm{MeOH}(4.0 \mathrm{~mL})$ and water $(40 \mathrm{~mL})$ at $0{ }^{\circ} \mathrm{C}$ was added $\mathrm{NaBH}_{4}(742 \mathrm{mg}, 19.6 \mathrm{mmol})$ portionwise. The solution was stirred at $\mathrm{rt}$ for $3 \mathrm{~h}$, before being cooled to $0{ }^{\circ} \mathrm{C}$ for addition of 
a further portion of $\mathrm{NaBH}_{4}(742 \mathrm{mg}, 19.6 \mathrm{mmol})$. The resulting mixture was stirred at $\mathrm{rt}$ for 18 h. The reaction was quenched with aq. $1 \mathrm{M} \mathrm{HCl}(40 \mathrm{~mL})$ and the resulting mixture was stirred for $1 \mathrm{~h}$ before being concentrated in vacuo. The residue was redissolved in $\mathrm{CH}_{2} \mathrm{Cl}_{2} /$ acetone, filtered, and concentrated in vacuo. The crude product was purified by flash column chromatography $\left(\mathrm{CH}_{2} \mathrm{Cl}_{2} / \mathrm{MeOH}\right.$ 95:5 to 80:20) to afford the title compound $\mathbf{4 5}$ as a yellow oil (195 mg, 59\%). R $\mathrm{R}_{\mathrm{f}} 0.40\left(\mathrm{CH}_{2} \mathrm{Cl}_{2} / \mathrm{MeOH} 90: 10\right) ;[\alpha]_{\mathrm{D}}{ }^{30}-14.5$ (c 0.91, MeOH); IR 3340 (br. m), 2939 (w), 2359 (w), 1042 (s) cm ${ }^{-1} ;{ }^{1} \mathrm{H}$ NMR (500 MHz, MeOD) $\delta 4.78$ (1H, dqd, $J=48.8,6.0$, $\left.3.3 \mathrm{~Hz}, \mathrm{H}_{5}\right), 4.65\left(1 \mathrm{H}\right.$, dddd, $\left.J=48.6,8.3,6.0,3.6 \mathrm{~Hz}, \mathrm{H}_{3}\right), 3.76-3.57$ (5H, m, $\left.\mathrm{H}_{1+2+6}\right), 2.21-$ $2.00\left(2 \mathrm{H}, \mathrm{m}, \mathrm{H}_{4}\right) \mathrm{ppm} ;{ }^{1} \mathrm{H}\left\{{ }^{19} \mathrm{~F}\right\} \mathrm{NMR}(500 \mathrm{MHz}, \mathrm{MeOD}) \delta 4.74(1 \mathrm{H}, \mathrm{qd}, J=6.0,3.3 \mathrm{~Hz}, \mathrm{H} 5)$, $4.62\left(1 \mathrm{H}, \mathrm{ddd}, J=8.3,6.0,3.6 \mathrm{~Hz}, \mathrm{H}_{3}\right), 3.74-3.64\left(4 \mathrm{H}, \mathrm{m}, \mathrm{H}_{1+2+6}\right), 3.59(1 \mathrm{H}, \mathrm{dd}, J=11.4,5.9$ $\left.\mathrm{Hz}, \mathrm{H}_{1}{ }^{\prime}\right), 2.16-2.04\left(2 \mathrm{H}, \mathrm{m}, \mathrm{H}_{4}\right) \mathrm{ppm} ;{ }^{13} \mathrm{C}\left\{{ }^{1} \mathrm{H}\right\} \mathrm{NMR}$ (126 MHz, MeOD), $\delta 91.7$ (dd, $J_{\mathrm{C}-\mathrm{F}}=$ 169.8, 2.7 Hz, C5), $90.3\left(\mathrm{dd}, J_{\mathrm{C}-\mathrm{F}}=170.8,5.5 \mathrm{~Hz}, \mathrm{C}_{3}\right), 72.7\left(\mathrm{~d}, J_{\mathrm{C}-\mathrm{F}}=23.6 \mathrm{~Hz}, \mathrm{C}_{2}\right), 63.3\left(\mathrm{~d}, J_{\mathrm{C}-}\right.$ $\left.\mathrm{F}=22.7 \mathrm{~Hz}, \mathrm{C}_{6}\right), 62.1\left(\mathrm{~d}, J_{\mathrm{C}-\mathrm{F}}=6.4 \mathrm{~Hz}, \mathrm{C}_{1}\right), 32.2\left(\mathrm{t}, J_{\mathrm{C}-\mathrm{F}}=20.9 \mathrm{~Hz}, \mathrm{C}_{4}\right) \mathrm{ppm} ;{ }^{19} \mathrm{~F}$ NMR $(471$ MHz, MeOD) $\delta-189.3$ to -189.6 (m, F5), -191.0 to $-191.3\left(\mathrm{~m}, \mathrm{~F}_{3}\right) \mathrm{ppm} ;{ }^{19} \mathrm{~F}\left\{{ }^{1} \mathrm{H}\right\} \mathrm{NMR}(471$ MHz, MeOD) $\delta-189.5(\mathrm{~d}, J=3.2 \mathrm{~Hz}, \mathrm{~F} 5),-191.1\left(\mathrm{~d}, J=2.9 \mathrm{~Hz}, \mathrm{~F}_{3}\right) \mathrm{ppm}$; HRMS (ESI) m/z: $[\mathrm{M}+\mathrm{Na}]^{+}$, Calcd for $\mathrm{C}_{6} \mathrm{H}_{12} \mathrm{~F}_{2} \mathrm{NaO}_{3}$ 193.0647; Found 193.0650.

(3S,5R)-3,5-Difluorotetrahydro-2H-pyran-2-ol (46). To a solution of 45 (218 $\mathrm{mg}, 1.28$ mmol) in water $(20 \mathrm{~mL})$ at $0{ }^{\circ} \mathrm{C}$ was added $\mathrm{NaIO}_{4}(411 \mathrm{mg}, 1.92 \mathrm{mmol})$. The resulting mixture was warmed to $\mathrm{rt}$ and stirred for $3 \mathrm{~h}$ before being diluted with water $(20 \mathrm{~mL})$ and concentrated in vacuo. The residue was redissolved in acetone $/ \mathrm{CH}_{2} \mathrm{Cl}_{2}$ and the insoluble material was removed by filtration. The filtrate was concentrated in vacuo. The crude product was purified by flash column chromatography (hexane/acetone 80:20) to afford the title compound $\mathbf{4 6}$ as a white crystalline solid $(151 \mathrm{mg}, 84 \%)$. $\mathrm{R}_{\mathrm{f}} 0.32$ (hexane/acetone $\left.80: 20\right) ;[\alpha]_{\mathrm{D}}^{30}+12.9(\mathrm{c} 0.7$, $\mathrm{CHCl}_{3}$ ); mp 65-68 ${ }^{\circ} \mathrm{C}$ (hexane/acetone); IR 3394 (br. m), 2949 (w), 1098 (s), 1036 (s) cm cm $^{-1}$ ${ }^{1} \mathrm{H}$ NMR $\left(500 \mathrm{MHz}, \mathrm{CDCl}_{3}, \alpha / \beta\right.$ 1.00:0.42) $\delta 5.25\left(1 \mathrm{H}\right.$, br. d, $\left.J=7.9 \mathrm{~Hz}, \mathrm{H}_{1 \alpha}\right), 4.90(1 \mathrm{H}, \mathrm{dt}, J$ 
$\left.=12.2,2.0 \mathrm{~Hz}, \mathrm{H}_{1 \beta}\right), 4.70-4.58\left(3 \mathrm{H}, \mathrm{m}, \mathrm{H}_{2 \beta+4 \alpha+4 \beta}\right), 4.50\left(1 \mathrm{H}, \mathrm{dq}, J=44.9,3.4 \mathrm{~Hz}, \mathrm{H}_{2 \alpha}\right), 4.15$ $\left(1 \mathrm{H}, \mathrm{ddd}, J=37.1,13.4,1.8 \mathrm{~Hz}, \mathrm{H}_{5 \mathrm{ax} \alpha}\right), 4.15-4.09\left(1 \mathrm{H}, \mathrm{m}, \mathrm{H}_{5 \mathrm{eq} \beta}\right), 3.86(1 \mathrm{H}, \mathrm{tt}, J=13.5,2.5 \mathrm{~Hz}$, $\left.\mathrm{H}_{5 \mathrm{eq} \alpha}\right), 3.74\left(1 \mathrm{H}\right.$, dddt, $\left.J=24.5,12.5,2.8,1.1 \mathrm{~Hz}, \mathrm{H}_{5 \mathrm{ax} \beta}\right), 3.34\left(1 \mathrm{H}\right.$, br. s, $\left.\mathrm{OH}_{\alpha+\beta}\right), 2.50(1 \mathrm{H}$, dttd, $\left.J=14.4,11.5,5.9,2.1 \mathrm{~Hz}, \mathrm{H}_{3 \mathrm{eq} \beta}\right), 2.38-2.10\left(4 \mathrm{H}, \mathrm{m}, \mathrm{H}_{3 \alpha+3 \mathrm{ax} \beta}\right) \mathrm{ppm} ; 1 \mathrm{H}\left\{{ }^{19} \mathrm{~F}\right\} \mathrm{NMR}(500$ $\left.\mathrm{MHz}, \mathrm{CDCl}_{3}\right) \delta 5.25\left(1 \mathrm{H}\right.$, br. $\left.\mathrm{d}, J=1.9 \mathrm{~Hz}, \mathrm{H}_{1 \alpha}\right), 4.89\left(1 \mathrm{H}, \mathrm{d}, J=1.9 \mathrm{~Hz}, \mathrm{H}_{1 \beta}\right), 4.65-4.63(1 \mathrm{H}$, $\left.\mathrm{m}, \mathrm{H}_{4 \alpha}\right), 4.62-4.58\left(2 \mathrm{H}, \mathrm{m}, \mathrm{H}_{2 \beta+4 \beta}\right), 4.50\left(1 \mathrm{H}, \mathrm{q}, J=3.2 \mathrm{~Hz}, \mathrm{H}_{2 \alpha}\right), 4.15(1 \mathrm{H}, \mathrm{dd}, J=13.4,1.8$ $\left.\mathrm{Hz}, \mathrm{H}_{5 \mathrm{ax} \alpha}\right), 4.12\left(1 \mathrm{H}, \mathrm{ddd}, J=12.4,4.9,2.0 \mathrm{~Hz}, \mathrm{H}_{5 \mathrm{eq} \beta}\right), 3.86\left(1 \mathrm{H}, \mathrm{dt}, J=13.0,2.5 \mathrm{~Hz}, \mathrm{H}_{5 \mathrm{eq} \alpha}\right)$, $3.73\left(1 \mathrm{H}, \mathrm{ddd}, J=12.5,2.9,1.0 \mathrm{~Hz}, \mathrm{H}_{5 \mathrm{ax} \beta}\right), 3.33\left(1 \mathrm{H}\right.$, br. s, $\left.\mathrm{OH}_{\alpha+\beta}\right), 2.49(1 \mathrm{H}, \mathrm{dtd}, J=14.4$, 5.9, 2.1 Hz, $\left.\mathrm{H}_{3 \mathrm{eq} \beta}\right), 2.33\left(1 \mathrm{H}, \mathrm{dddt}, J=15.6,4.7,3.5,1.1 \mathrm{~Hz}, \mathrm{H}_{3 \mathrm{eq} \alpha}\right), 2.22(1 \mathrm{H}, \mathrm{dt}, J=15.6,3.5$ $\left.\mathrm{Hz}, \mathrm{H}_{3 \mathrm{ax} \alpha}\right), 2.19-2.15\left(1 \mathrm{H}, \mathrm{m}, \mathrm{H}_{3 \mathrm{ax} \beta}\right) \mathrm{ppm} ;{ }^{13} \mathrm{C}\left\{{ }^{1} \mathrm{H}\right\} \mathrm{NMR}\left(126 \mathrm{MHz}, \mathrm{CDCl}_{3}\right) \delta 91.7\left(\mathrm{~d}, J_{\mathrm{C}-\mathrm{F}}=\right.$ $\left.19.3 \mathrm{~Hz}, \mathrm{C}_{1 \beta}\right), 91.2\left(\mathrm{~d}, J_{\mathrm{C}-\mathrm{F}}=31.2 \mathrm{~Hz}, \mathrm{C}_{1 \alpha}\right), 85.6\left(\mathrm{dd}, J_{\mathrm{C}-\mathrm{F}}=182.9,4.0 \mathrm{~Hz}, \mathrm{C}_{2 \beta}\right), 84.6\left(\mathrm{~d}, J_{\mathrm{C}-\mathrm{F}}=\right.$ $\left.174.3 \mathrm{~Hz}, \mathrm{C}_{2 \alpha}\right), 83.9\left(\mathrm{~d}, J_{\mathrm{C}-\mathrm{F}}=177.4 \mathrm{~Hz}, \mathrm{C}_{4 \alpha}\right), 83.2\left(\mathrm{dd}, J_{\mathrm{C}-\mathrm{F}}=178.3,4.0 \mathrm{~Hz}, \mathrm{C}_{4 \beta}\right), 65.0\left(\mathrm{~d}, J_{\mathrm{C}-}\right.$ $\left.\mathrm{F}=24.1 \mathrm{~Hz}, \mathrm{C}_{5 \beta}\right), 61.5\left(\mathrm{~d}, J_{\mathrm{C}-\mathrm{F}}=21.9 \mathrm{~Hz}, \mathrm{C}_{5 \alpha}\right), 31.6\left(\mathrm{t}, J_{\mathrm{C}-\mathrm{F}}=20.7 \mathrm{~Hz}, \mathrm{C}_{3 \beta}\right), 28.2\left(\mathrm{t}, J_{\mathrm{C}-\mathrm{F}}=20.5\right.$ $\mathrm{Hz}, \mathrm{C}_{3 \alpha}$ ) ppm; ${ }^{19} \mathrm{~F} \mathrm{NMR}\left(471 \mathrm{MHz}, \mathrm{CDCl}_{3}\right) \delta-183.7$ to $-184.1\left(\mathrm{~m}, \mathrm{~F}_{4 \alpha}\right),-185.6$ to $-185.9(\mathrm{~m}$, $\left.\mathrm{F}_{4 \beta}\right),-186.5$ to $-186.8\left(\mathrm{~m}, \mathrm{~F}_{2 \alpha}\right),-200.7$ to $-201.0\left(\mathrm{~m}, \mathrm{~F}_{2 \beta}\right) \mathrm{ppm} ;{ }^{19} \mathrm{~F}\left\{{ }^{1} \mathrm{H}\right\} \mathrm{NMR}(471 \mathrm{MHz}$, $\left.\mathrm{CDCl}_{3}\right) \delta-183.9\left(\mathrm{~d}, J=14.3 \mathrm{~Hz}, \mathrm{~F}_{4 \alpha}\right),-185.8\left(\mathrm{~d}, J=9.3 \mathrm{~Hz}, \mathrm{~F}_{4 \beta}\right),-186.7\left(\mathrm{~d}, J=14.3 \mathrm{~Hz}, \mathrm{~F}_{2 \alpha}\right)$, -200.9 (br. s, $\mathrm{F}_{2} \beta$ ) ppm; HRMS (ESI) m/z: $[\mathrm{M}+\mathrm{Na}]^{+} \mathrm{Calcd}$ for $\mathrm{C}_{5} \mathrm{H}_{8} \mathrm{~F}_{2} \mathrm{NaO}_{2}$ 161.0385; Found 161.0389 .

1-(Benzyloxy)-2-fluorohex-5-ene (47). To a solution of $\mathbf{3 1}{ }^{66}$ (206 mg, $\left.1.0 \mathrm{mmol}\right)$ in dry THF (4 mL) at rt was added in sequence: Et $3 \mathrm{~N}(0.84 \mathrm{~mL}, 6.0 \mathrm{mmol}), \mathrm{Et}_{3} \mathrm{~N} \cdot 3 \mathrm{HF}(0.33 \mathrm{~mL}, 2.0 \mathrm{mmol})$ and $\mathrm{NfF}(0.36 \mathrm{~mL}, 2.0 \mathrm{mmol})$. After $24 \mathrm{~h}$, the reaction was quenched by slow addition of sat. aq. $\mathrm{NaHCO}_{3}(4 \mathrm{~mL})$. Water $(1 \mathrm{~mL})$ was added and the solution stirred vigorously for $30 \mathrm{~min}$. The phases were separated and the aqueous phase extracted with $\mathrm{Et}_{2} \mathrm{O}(3 \times 10 \mathrm{~mL})$. The combined organics were washed with sat. brine $(10 \mathrm{~mL})$, dried over $\mathrm{MgSO}_{4}$, and concentrated in vacuo. The crude product was purified by flash column chromatography (hexane/EtOAc 
100:0 to 90:10) to afford the title compound 47 as a colourless oil (145 $\mathrm{mg}, 70 \%)$. Rf 0.59 (hexane/EtOAc 80:20); IR 3656 (w), 3067 (w), 2980 (s), 1092 (s), 736 (s), 697 (s) cm ${ }^{-1}$; ${ }^{1} \mathrm{H}$ NMR (400 MHz, $\left.\mathrm{CDCl}_{3}\right) \delta$ 7.40-7.29 (5H, m, Hph), $5.83\left(1 \mathrm{H}, \mathrm{ddt}, J=17.0,10.3,6.6 \mathrm{~Hz}, \mathrm{H}_{5}\right)$, $5.07\left(1 \mathrm{H}, \mathrm{dq}, J=17.1,1.7 \mathrm{~Hz}, \mathrm{H}_{6}{ }^{\prime}\right), 5.02\left(1 \mathrm{H}, \mathrm{dq}, J=10.2,1.41 \mathrm{~Hz}, \mathrm{H}_{6}{ }^{\prime}\right), 4.79-4.62(1 \mathrm{H}, \mathrm{m}$, $\left.\mathrm{d}_{\mathrm{obs}}, J=49.2 \mathrm{~Hz}, \mathrm{H}_{2}\right), 4.61\left(2 \mathrm{H}, \mathrm{s}, \mathrm{H}_{\mathrm{Bn}}\right), 3.65-3.63\left(1 \mathrm{H}, \mathrm{m}, \mathrm{H}_{1}\right), 3.59-3.57\left(1 \mathrm{H}, \mathrm{m}, \mathrm{H}_{1^{\prime}}\right), 2.30-$ $2.12\left(2 \mathrm{H}, \mathrm{m}, \mathrm{H}_{4}\right), 1.90-1.61\left(2 \mathrm{H}, \mathrm{m}, \mathrm{H}_{3}\right) \mathrm{ppm} ;{ }^{13} \mathrm{C}\left\{{ }^{1} \mathrm{H}\right\} \mathrm{NMR}\left(101 \mathrm{MHz}, \mathrm{CDCl}_{3}\right) 137.9\left(\mathrm{C}_{\mathrm{Ph}}\right)$, $137.4\left(\mathrm{C}_{5}\right), 128.4\left(\mathrm{CPh}_{\mathrm{Ph}}\right), 127.71\left(\mathrm{CPh}_{\mathrm{Ph}}\right), 127.67\left(\mathrm{C}_{\mathrm{Ph}}\right), 115.3\left(\mathrm{C}_{6}\right), 92.3\left(\mathrm{~d}, J_{\mathrm{C}-\mathrm{F}}=170.9 \mathrm{~Hz}, \mathrm{C}_{2}\right)$, $73.4\left(\mathrm{C}_{\mathrm{Bn}}\right), 71.8\left(\mathrm{~d}, J_{\mathrm{C}-\mathrm{F}}=22.0 \mathrm{~Hz}, \mathrm{C}_{1}\right), 30.7\left(\mathrm{~d}, J_{\mathrm{C}-\mathrm{F}}=20.5 \mathrm{~Hz}, \mathrm{C}_{3}\right), 29.0\left(\mathrm{~d}, J_{\mathrm{C}-\mathrm{F}}=4.4 \mathrm{~Hz}, \mathrm{C}_{4}\right)$ ppm; ${ }^{19} \mathrm{~F}$ NMR $\left(376 \mathrm{MHz}, \mathrm{CDCl}_{3}\right) \delta-187.2\left(\mathrm{ddtd}, J=48.0,31.1,23.7,15.6 \mathrm{~Hz}, \mathrm{~F}_{2}\right) \mathrm{ppm}$; ${ }^{19} \mathrm{~F}\left\{{ }^{1} \mathrm{H}\right\}$ NMR $\left(376 \mathrm{MHz}, \mathrm{CDCl}_{3}\right) \delta-188.0\left(\mathrm{~s}, \mathrm{~F}_{2}\right) \mathrm{ppm}$; HRMS (EI) m/z: [M $]^{+}$Calcd for $\mathrm{C}_{13} \mathrm{H}_{17} \mathrm{FO} 208.1258$; Found 208.1255.

5-(Benzyloxy)-2,2,4-trifluoropentan-1-ol (48). To a stirred solution of $\mathbf{3 0}$ (212 mg, 1.00 $\mathrm{mmol})$ in dry THF ( $5 \mathrm{~mL}$ ) was added L-proline (46 mg, $0.40 \mathrm{mmol})$. After $5 \mathrm{~min}$, NFSI (788 $\mathrm{mg}, 2.50 \mathrm{mmol}$ ) was added portionwise and the mixture was stirred at $\mathrm{rt}$ for $23 \mathrm{~h}$. The reaction mixture was cooled to $0{ }^{\circ} \mathrm{C}$ and quenched by slow addition of dimethyl sulfide $(0.15 \mathrm{~mL}, 2.0$ mmol). After stirring for $30 \mathrm{~min}$ at $\mathrm{rt}$, the phases were separated and the aqueous phase extracted with EtOAc $(3 \times 5 \mathrm{~mL})$. The combined organic layers were washed with sat. aq. $\mathrm{NaHCO}_{3}(2 \times 5 \mathrm{~mL})$, sat brine $(5 \mathrm{~mL})$, dried over $\mathrm{MgSO}_{4}$, and concentrated in vacuo. The residue was redissolved in a mixture of $\mathrm{CH}_{2} \mathrm{Cl}_{2}(6 \mathrm{~mL})$ and $\mathrm{EtOH}(4 \mathrm{~mL})$ and cooled to $0{ }^{\circ} \mathrm{C}$. $\mathrm{NaBH}_{4}(94 \mathrm{mg}, 2.5 \mathrm{mmol}$ ) was added portionwise and the mixture stirred at $\mathrm{rt}$ for $30 \mathrm{~min}$. The reaction was quenched at $0{ }^{\circ} \mathrm{C}$ by cautious addition of sat. aq. $\mathrm{NH}_{4} \mathrm{Cl}(10 \mathrm{~mL})$ and stirred vigorously for 30 min at $\mathrm{rt}$. The phases were separated and the aqueous phase extracted with $\mathrm{CH}_{2} \mathrm{Cl}_{2}(3 \times 20 \mathrm{~mL})$. The combined organic phases were dried over $\mathrm{MgSO}_{4}$, and concentrated in vacuo. The crude product was purified by flash column chromatography (hexane/EtOAc 70:30) to afford the title compound $\mathbf{4 8}$ as colourless oil (202 mg, 81\%). Rf 0.33 (hexane/EtOAc 
70:30); IR 3393 (br. m), 2980 (m), 1367 (m), 1071 (s) cm ${ }^{-1} ;{ }^{1} \mathrm{H}$ NMR (400 MHz, CDCl $) \delta$ 7.40-7.29 (5H, m, HPh), 5.07-4.89 (1H, m, dobs, $\left.J=48.5 \mathrm{~Hz}, \mathrm{H}_{4}\right), 4.63(1 \mathrm{H}, \mathrm{d}, J=12.1 \mathrm{~Hz}$,

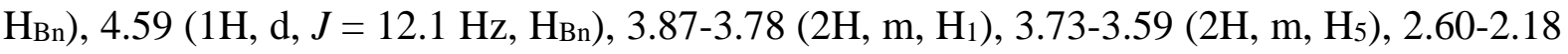
$\left(2 \mathrm{H}, \mathrm{m}, \mathrm{H}_{3}\right), 1.92(1 \mathrm{H}, \mathrm{t}, J=6.9 \mathrm{~Hz}, \mathrm{OH}) \mathrm{ppm} ;{ }^{13} \mathrm{C}\left\{{ }^{1} \mathrm{H}\right\} \mathrm{NMR}\left(101 \mathrm{MHz}, \mathrm{CDCl}_{3}\right) \delta 137.5$ $\left(\mathrm{CPh}_{\mathrm{Ph}}\right), 128.5\left(\mathrm{CPh}_{\mathrm{Ph}}\right), 127.9\left(\mathrm{CPh}_{\mathrm{Ph}}\right), 127.7\left(\mathrm{CPh}_{\mathrm{Ph}}\right), 121.9\left(\mathrm{t}, J_{\mathrm{C}-\mathrm{F}}=242.8 \mathrm{~Hz}, \mathrm{C}_{2}\right), 87.8\left(\mathrm{ddd}, J_{\mathrm{C}-\mathrm{F}}=\right.$ 171.7, 7.3, 3.7 Hz, $\left.\mathrm{C}_{4}\right), 73.6\left(\mathrm{C}_{\mathrm{Bn}}\right), 71.3\left(\mathrm{~d}, J_{\mathrm{C}-\mathrm{F}}=23.5 \mathrm{~Hz}, \mathrm{C}_{5}\right), 64.2\left(\mathrm{ddd}, J_{\mathrm{C}-\mathrm{F}}=33.0,29.3\right.$, $\left.2.9 \mathrm{~Hz}, \mathrm{C}_{1}\right), 35.7\left(\mathrm{ddd}, J_{\mathrm{C}-\mathrm{F}}=25.7,24.2,22.0 \mathrm{~Hz}, \mathrm{C}_{3}\right) \mathrm{ppm} ;{ }^{19} \mathrm{~F} \mathrm{NMR}\left(376 \mathrm{MHz}, \mathrm{CDCl}_{3}\right) \delta$ -103.7 to $-104.5\left(1 \mathrm{~F}, \mathrm{~m}, \mathrm{~d}_{\mathrm{obs}}, J=254.9 \mathrm{~Hz}, \mathrm{~F}_{2}\right),-108.2$ to $-109.1\left(1 \mathrm{~F}, \mathrm{~m}, \mathrm{~d}_{\mathrm{obs}}, J=254.9 \mathrm{~Hz}\right.$, $\left.\mathrm{F}_{2}{ }^{\prime}\right),-185.8$ to $-186.2\left(1 \mathrm{~F}, \mathrm{~m}, \mathrm{~F}_{4}\right) \mathrm{ppm} ;{ }^{19} \mathrm{~F}\left\{{ }^{1} \mathrm{H}\right\} \mathrm{NMR}\left(376 \mathrm{MHz}, \mathrm{CDCl}_{3}\right) \delta-104.0(1 \mathrm{~F}, \mathrm{dd}, J$ $\left.=256.6,5.2 \mathrm{~Hz}, \mathrm{~F}_{2}\right),-108.5\left(1 \mathrm{~F}, \mathrm{dd}, J=254.9,5.2 \mathrm{~Hz}, \mathrm{~F}_{2}{ }^{\prime}\right),-186.0\left(1 \mathrm{~F}, \mathrm{t}, J=4.3 \mathrm{~Hz}, \mathrm{~F}_{4}\right) \mathrm{ppm}$; HRMS (EI) m/z: [M] $]^{+}$Calcd for $\mathrm{C}_{12} \mathrm{H}_{15} \mathrm{~F}_{3} \mathrm{O}_{2} 248.1019$; Found 248.1019.

Ethyl 4,4-difluoro-5-hydroxypentanoate (49). Synthesized with a procedure of Kim et al. ${ }^{60}$ $\mathrm{Cu}$ powder $(3.33 \mathrm{~g}, 52.4 \mathrm{mmol})$, ethyl acrylate $35(2.72 \mathrm{~mL}, 25.0 \mathrm{mmol})$, and ethyl bromodifluoroacetate $36(5.78 \mathrm{~mL}, 45.1 \mathrm{mmol})$ were suspended in dry THF (29 mL) and heated to $50{ }^{\circ} \mathrm{C}$. TMEDA $(1.87 \mathrm{~mL}, 12.5 \mathrm{mmol})$ and $\mathrm{AcOH}(1.29 \mathrm{~mL}, 22.5 \mathrm{mmol})$ were added sequentially and the mixture was stirred for $1 \mathrm{~h}$ before being cooled to rt. MTBE (44 mL) and aq. $\mathrm{NH}_{4} \mathrm{Cl}(10 \mathrm{wt} . \%, 29 \mathrm{~mL})$ were added and the mixture stirred for a further $30 \mathrm{~min}$. The organic phase was separated and filtered through pad of Celite. The filtrate was washed with aq. $\mathrm{NH} 4 \mathrm{Cl} 10 \%(29 \mathrm{~mL})$, dried over $\mathrm{MgSO}_{4}$, and concentrated in vacuo to afford a yellow oil. This was redissolved in a mixture of THF $(28 \mathrm{~mL})$ and $\mathrm{EtOH}(5.6 \mathrm{~mL})$, and cooled to $0{ }^{\circ} \mathrm{C}$. $\mathrm{NaBH}_{4}(950 \mathrm{mg}, 25 \mathrm{mmol})$ was added portionwise. The mixture was warmed to $\mathrm{rt}$ and stirred for $30 \mathrm{~min}$. The mixture was cooled to $0{ }^{\circ} \mathrm{C}$ and quenched by slow addition of sat. aq. $\mathrm{NH}_{4} \mathrm{Cl}$ (25 mL). After stirring for a further $30 \mathrm{~min}$, the mixture was filtered through pad of Celite to remove the insoluble solids. The organic solvent was removed in vacuo and the residue subsequently extracted with EtOAc $(3 \times 100 \mathrm{~mL})$. The combined organic layers were dried 
over $\mathrm{MgSO}_{4}$ and concentrated in vacuo. The crude product was purified by flash column chromatography (hexane/ acetone 80:20) to afford the title compound $\mathbf{4 9}$ as a colourless oil (3.20 g, 70\% over two steps). Rf 0.10 (hexane/EtOAc 80:20); IR 3449 (br. m), 2985 (w), 1716 (s), $1071(\mathrm{~s}) \mathrm{cm}^{-1} ;{ }^{1} \mathrm{H}$ NMR (400 MHz, $\left.\mathrm{CDCl}_{3}\right) \delta 4.17\left(2 \mathrm{H}, \mathrm{q}, J=7.2 \mathrm{~Hz}, \mathrm{HoC}_{2} 2 \mathrm{CH} 3\right), 3.73(2 \mathrm{H}$, $\left.\mathrm{t}, J=12.5 \mathrm{~Hz}, \mathrm{H}_{5}\right), 2.56\left(2 \mathrm{H}, \mathrm{t}, J=7.5 \mathrm{~Hz}, \mathrm{H}_{2}\right), 2.42(1 \mathrm{H}$, br. s, OH), $2.30(2 \mathrm{H}, \mathrm{tt}, J=16.8,7.5$ $\left.\mathrm{Hz}, \mathrm{H}_{3}\right), 1.28(3 \mathrm{H}, \mathrm{t}, J=7.2 \mathrm{~Hz}, \mathrm{Hoch} 2 \mathrm{C} 33) \mathrm{ppm} ;{ }^{13} \mathrm{C}\left\{{ }^{1} \mathrm{H}\right\} \mathrm{NMR}\left(101 \mathrm{MHz}, \mathrm{CDCl}_{3}\right) \delta 172.8$ $\left(\mathrm{C}_{1}\right), 122.5\left(\mathrm{t}, J_{\mathrm{C}-\mathrm{F}}=246.5 \mathrm{~Hz}, \mathrm{C}_{4}\right), 63.9\left(\mathrm{t}, J_{\mathrm{C}-\mathrm{F}}=32.3 \mathrm{~Hz}, \mathrm{C}_{5}\right), 61.0\left(\mathrm{C}_{\mathrm{OCH} 2 \mathrm{CH} 3}\right), 28.4\left(\mathrm{t}, J_{\mathrm{C}-\mathrm{F}}\right.$ $\left.=24.9 \mathrm{~Hz}, \mathrm{C}_{3}\right), 26.9\left(\mathrm{t}, J_{\mathrm{C}-\mathrm{F}}=5.1 \mathrm{~Hz}, \mathrm{C}_{2}\right), 14.1\left(\mathrm{CoCH}_{2} \mathrm{CH} 3\right) \mathrm{ppm} ;{ }^{19} \mathrm{~F} \mathrm{NMR}\left(376 \mathrm{MHz}, \mathrm{CDCl}_{3}\right)$ $\delta-109.2\left(\mathrm{tt}, J=17.3,12.1 \mathrm{~Hz}, \mathrm{~F}_{4}\right) \mathrm{ppm} ;{ }^{19} \mathrm{~F}\left\{{ }^{1} \mathrm{H}\right\} \mathrm{NMR}\left(376 \mathrm{MHz}, \mathrm{CDCl}_{3}\right) \delta-109.2\left(\mathrm{~s}, \mathrm{~F}_{4}\right)$ ppm; HRMS (EI) m/z: [M- $]^{+}$Calcd for $\mathrm{C}_{7} \mathrm{H}_{12} \mathrm{~F}_{2} \mathrm{O}_{3}$ 182.0749; Found 182.0749.

Ethyl 5-((tert-butyldiphenylsilyl)oxy)-4,4-difluoropentanoate (50). To a stirred solution of 49 (3.00 g, $16.5 \mathrm{mmol}), 1 \mathrm{H}$-imidazole (1.35 g, $19.8 \mathrm{mmol})$, and DMAP (100 mg, $0.824 \mathrm{mmol})$ in dry $\mathrm{CH}_{2} \mathrm{Cl}_{2}(83 \mathrm{~mL})$ at $0{ }^{\circ} \mathrm{C}$ was added TBDPSCl $(5.43 \mathrm{~g}, 19.8 \mathrm{mmol})$ portionwise. The reaction mixture was allowed to warm to $\mathrm{rt}$ and stirred for $16 \mathrm{~h}$. Water $(50 \mathrm{~mL})$ was added and the aqueous phase extracted with $\mathrm{CH}_{2} \mathrm{Cl}_{2}(3 \times 50 \mathrm{~mL})$. The combined organic layers were dried over $\mathrm{MgSO} 4$ and concentrated in vacuo. The crude product was purified by flash column chromatography (hexane/acetone 90:10) to afford the title compound $\mathbf{5 0}$ as a colourless oil (5.94 g, 86\%). Rf 0.59 (hexane/EtOAc 70:30); IR 3657 (m), 2980 (s), 2889 (s), 1736 (s), 1382 (s), $1088(\mathrm{~s}) \mathrm{cm}^{-1} ;{ }^{1} \mathrm{H}$ NMR $\left(400 \mathrm{MHz}, \mathrm{CDCl}_{3}\right) \delta$ 7.69-7.66 (4H, m, HPh), 7.49-7.40 (6H, m, HPh), 4.18 (2H, q, $\left.J=7.1 \mathrm{~Hz}, \mathrm{Hoch}_{2} \mathrm{CH} 3\right), 3.77(2 \mathrm{H}, \mathrm{t}, J=12.0 \mathrm{~Hz}, \mathrm{H} 5), 2.57-2.53\left(2 \mathrm{H}, \mathrm{m}, \mathrm{H}_{2}\right)$, 2.44-2.31 (2H, m, H3), $1.29(3 \mathrm{H}, \mathrm{t}, J=7.1 \mathrm{~Hz}, \mathrm{Hoch2} \underline{\mathrm{CH}} 3), 1.09\left(9 \mathrm{H}, \mathrm{s}, \mathrm{H}_{t \mathrm{Bu}}\right) \mathrm{ppm} ;{ }^{13} \mathrm{C}\left\{{ }^{1} \mathrm{H}\right\}$ NMR (101 MHz, $\left.\mathrm{CDCl}_{3}\right) \delta 172.4\left(\mathrm{C}_{1}\right), 135.6\left(\mathrm{CPh}_{\mathrm{Ph}}\right), 132.5\left(\mathrm{CPh}_{\mathrm{Ph}}\right), 130.0\left(\mathrm{CPh}_{\mathrm{Ph}}\right), 127.8\left(\mathrm{CPh}_{\mathrm{Ph}}\right), 122.5$ $\left(\mathrm{t}, J_{\mathrm{C}-\mathrm{F}}=242.8 \mathrm{~Hz}, \mathrm{C}_{4}\right), 65.1\left(\mathrm{t}, J_{\mathrm{C}-\mathrm{F}}=34.1 \mathrm{~Hz}, \mathrm{C}_{5}\right), 60.7\left(\mathrm{CoCH}_{2} \mathrm{CH} 3\right), 28.9\left(\mathrm{t}, J_{\mathrm{C}-\mathrm{F}}=24.2 \mathrm{~Hz}\right.$, $\left.\mathrm{C}_{3}\right), 26.9\left(\mathrm{t}, J_{\mathrm{C}-\mathrm{F}}=4.8 \mathrm{~Hz}, \mathrm{C}_{2}\right), 26.7\left(\mathrm{C}_{t \mathrm{Bu}}, \mathrm{Me}\right), 19.2\left(\mathrm{C}_{t \mathrm{Bu}, \mathrm{quat}}\right), 14.2\left(\mathrm{CoCH}_{2} \mathrm{CH} 3\right) \mathrm{ppm} ;{ }^{19} \mathrm{~F} \mathrm{NMR}$ $\left(376 \mathrm{MHz}, \mathrm{CDCl}_{3}\right) \delta-108.5\left(\mathrm{tt}, J=17.3,12.1 \mathrm{~Hz}, \mathrm{~F}_{4}\right) \mathrm{ppm} ;{ }^{19} \mathrm{~F}\left\{{ }^{1} \mathrm{H}\right\} \mathrm{NMR}\left(376 \mathrm{MHz}, \mathrm{CDCl}_{3}\right)$ 
$\delta-108.5\left(\mathrm{~s}, \mathrm{~F}_{4}\right)$ ppm; HRMS (ESI) m/z: [M + Na $]^{+} \mathrm{Calcd}$ for $\mathrm{C}_{23} \mathrm{H}_{30} \mathrm{~F}_{2} \mathrm{NaO}_{3} \mathrm{Si}$ 443.1824; Found 443.1829.

5-((tert-Butyldiphenylsilyl)oxy)-2,2,4,4-tetrafluoropentan-1-ol (51). To a stirred solution of 33 (897 mg, $2.38 \mathrm{mmol})$ in dry THF (12 mL) was added L-proline (109 mg, $0.95 \mathrm{mmol})$. After $5 \mathrm{~min}$, NFSI (1.88 $\mathrm{g}, 5.96 \mathrm{mmol})$ was added portionwise and the mixture was stirred at $\mathrm{rt}$ for $19 \mathrm{~h}$. The reaction mixture was cooled to $0{ }^{\circ} \mathrm{C}$ and quenched by slow addition of dimethylsulfide $(0.35 \mathrm{~mL}, 4.8 \mathrm{mmol})$. After stirring for $30 \mathrm{~min}$ at rt, sat. aq. $\mathrm{NaHCO}_{3}(25 \mathrm{~mL})$ was added. The aqueous phase was extracted with EtOAc $(3 \times 25 \mathrm{~mL})$ and the combined organic layers washed with sat. brine $(25 \mathrm{~mL})$, dried over $\mathrm{MgSO}_{4}$ and concentrated in vacuo. The crude oil was redissolved in a mixture of dry $\mathrm{CH}_{2} \mathrm{Cl}_{2}(14.3 \mathrm{~mL})$ and $\mathrm{EtOH}(9.5 \mathrm{~mL})$ and cooled to $0{ }^{\circ} \mathrm{C}$. $\mathrm{NaBH}_{4}(225 \mathrm{mg}, 5.96 \mathrm{mmol})$ was added portionwise and the mixture stirred at rt for 30 min. The reaction was quenched at $0{ }^{\circ} \mathrm{C}$ by cautious addition of sat. aq. $\mathrm{NH}_{4} \mathrm{Cl}(25$ $\mathrm{mL}$ ) and stirred vigorously for $1 \mathrm{~h}$ at $\mathrm{rt}$. The phases were separated and the aqueous phase extracted with $\mathrm{CH}_{2} \mathrm{Cl}_{2}(3 \times 50 \mathrm{~mL})$. The combined organic phases were dried over $\mathrm{MgSO}_{4}$ and concentrated in vacuo. The crude product was purified by flash column chromatography (hexane/EtOAc 80:20) to afford the title compound $\mathbf{5 1}$ as a colourless oil (750 $\mathrm{mg}, \mathbf{7 6 \%}$ ). $\mathrm{Rf}$ 0.25 (hexane/EtOAc 80:20); IR 3656 (w), 3376 (br. w), 2980 (s), 2889 (m), 1382 (m), 1113 (s) $\mathrm{cm}^{-1},{ }^{1} \mathrm{H}$ NMR $\left(400 \mathrm{MHz}, \mathrm{CDCl}_{3}\right) \delta$ 7.68-7.66 (4H, m, HPh), 7.49-7.40 (6H, m, Hph), 3.87 (2H, td, $\left.J=13.0,7.2 \mathrm{~Hz}, \mathrm{H}_{1}\right), 3.82\left(2 \mathrm{H}, \mathrm{t}, J=12.2 \mathrm{~Hz}, \mathrm{H}_{5}\right), 2.80\left(2 \mathrm{H}\right.$, quin, $\left.J=15.9 \mathrm{~Hz}, \mathrm{H}_{3}\right), 1.93$ $(1 \mathrm{H}, \mathrm{t}, J=7.3 \mathrm{~Hz}, \mathrm{OH}), 1.09\left(9 \mathrm{H}, \mathrm{s}, \mathrm{H}_{\mathrm{tBu}}\right) \mathrm{ppm} ;{ }^{13} \mathrm{C}\left\{{ }^{1} \mathrm{H}\right\} \mathrm{NMR}\left(101 \mathrm{MHz}, \mathrm{CDCl}_{3}\right) \delta 135.5$ $(\mathrm{CPh}), 132.3(\mathrm{CPh}), 130.0(\mathrm{CPh}), 127.9(\mathrm{CPh}), 123.2-118.3\left(\mathrm{~m}, \mathrm{C}_{2+4}\right), 65.3\left(\mathrm{t}, J_{\mathrm{C}-\mathrm{F}}=33.4 \mathrm{~Hz}, \mathrm{C}_{1}\right)$, $64.3\left(\mathrm{t}, J_{\mathrm{C}-\mathrm{F}}=30.8 \mathrm{~Hz}, \mathrm{C}_{5}\right), 36.5\left(\right.$ quin, $\left.J_{\mathrm{C}-\mathrm{F}}=25.3 \mathrm{~Hz}, \mathrm{C}_{3}\right), 26.6\left(\mathrm{C}_{t \mathrm{Bu}, \mathrm{Me}}\right), 19.2\left(\mathrm{C}_{t \mathrm{Bu}, \text { quat }}\right) \mathrm{ppm}$; ${ }^{19} \mathrm{~F}$ NMR $\left(376 \mathrm{MHz}, \mathrm{CDCl}_{3}\right) \delta-103.9$ to -104.3 (m, $\left.\mathrm{F}_{2+4}\right) \mathrm{ppm} ;{ }^{19} \mathrm{~F}\left\{{ }^{1} \mathrm{H}\right\}$ NMR $(376 \mathrm{MHz}$, $\left.\mathrm{CDCl}_{3}\right) \delta-104.1\left(\mathrm{t}, J=8.7 \mathrm{~Hz}, \mathrm{~F}_{2}\right),-104.1\left(\mathrm{t}, J=8.7 \mathrm{~Hz}, \mathrm{~F}_{4}\right) \mathrm{ppm} ; \mathrm{HRMS}(\mathrm{ESI}) \mathrm{m} / \mathrm{z}:[\mathrm{M}+$ $\mathrm{Na}]^{+}$Calcd for $\mathrm{C}_{21} \mathrm{H}_{26} \mathrm{~F}_{4} \mathrm{NaO}_{2} \mathrm{Si}$ 437.1530; Found 437.1535. 
Diethyl 3-fluoropentane-1,5-dioate (54). To a solution of $\mathbf{5 3}(1.0 \mathrm{~g}, 4.9 \mathrm{mmol})$ in $\operatorname{dry~} \mathrm{CH}_{2} \mathrm{Cl}_{2}$ $(49 \mathrm{~mL})$ at $0{ }^{\circ} \mathrm{C}$ was added DAST $(1.3 \mathrm{~mL}, 9.8 \mathrm{mmol})$ dropwise. The solution was stirred at $\mathrm{rt}$ for $4 \mathrm{~h}$, then cooled to $0{ }^{\circ} \mathrm{C}$ and quenched by slow addition of sat. aq. $\mathrm{NaHCO}_{3}(150 \mathrm{~mL})$. After stirring vigorously at $\mathrm{rt}$ for $30 \mathrm{~min}$, the phases were separated and the aqueous phase extracted with $\mathrm{CH}_{2} \mathrm{Cl}_{2}(3 \times 100 \mathrm{~mL})$. The combined organics were dried over $\mathrm{MgSO}_{4}$, and concentrated in vacuo. The crude product was purified by flash column chromatography (hexane/acetone 80:20) to afford the title compound $\mathbf{5 4}$ as a yellow oil with a $10 \%$ impurity of the elimination by-product by mass (973 mg, 87\% calculated for the pure compound). Rf 0.39 (hexane/EtOAc 70:30); IR 2984 (m), 1731 (s), 1194 (s), 1152 (s), 1024 (s) cm ${ }^{-1} ;{ }^{1} \mathrm{H}$ NMR (400 MHz, CDCl 3 ) $\delta 5.37(1 \mathrm{H}, \mathrm{dtt}, J=46.7,7.3,5.1 \mathrm{~Hz}, \mathrm{H} 3), 4.19(2 \mathrm{H}, \mathrm{q}, J=7.3 \mathrm{~Hz}, \mathrm{Hoch} 2 \mathrm{CH} 3), 2.84-2.65$ (4H, $\left.\mathrm{m}, \mathrm{H}_{2+4}\right), 1.29\left(3 \mathrm{H}, \mathrm{t}, J=7.2 \mathrm{~Hz}, \mathrm{HoCH}_{2} \mathrm{CH} 3\right) \mathrm{ppm} ;{ }^{13} \mathrm{C}\left\{{ }^{1} \mathrm{H}\right\} \mathrm{NMR}\left(101 \mathrm{MHz}, \mathrm{CDCl}_{3}\right) \delta 169.4$ $\left(\mathrm{d}, J_{\mathrm{C}-\mathrm{F}}=6.6 \mathrm{~Hz}, \mathrm{C}_{1+5}\right), 86.5\left(\mathrm{~d}, J_{\mathrm{C}-\mathrm{F}}=171.7 \mathrm{~Hz}, \mathrm{C}_{3}\right), 61.0\left(\mathrm{C}_{\underline{\mathrm{CH}} 2 \mathrm{CH} 3}\right), 39.7\left(\mathrm{~d}, J_{\mathrm{C}-\mathrm{F}}=23.5 \mathrm{~Hz}\right.$, $\left.\mathrm{C}_{2+4}\right), 14.1\left(\mathrm{CoCH}_{2} \underline{\mathrm{CH} 3}\right) \mathrm{ppm} ;{ }^{19} \mathrm{~F}$ NMR $\left(376 \mathrm{MHz}, \mathrm{CDCl}_{3}\right) \delta-179.3$ to $-179.7\left(\mathrm{~m}, \mathrm{~F}_{3}\right) \mathrm{ppm}$; ${ }^{19} \mathrm{~F}\left\{{ }^{1} \mathrm{H}\right\}$ NMR $\left(376 \mathrm{MHz}, \mathrm{CDCl}_{3}\right) \delta-184.8\left(\mathrm{~s}, \mathrm{~F}_{3}\right) \mathrm{ppm}$; HRMS (EI) m/z: [M- ${ }^{+}$Calcd for $\mathrm{C}_{9} \mathrm{H}_{15} \mathrm{FO}_{4}$ 206.0949; Found 206.0943.

1,4-Di(benzyloxy)-3-fluorobutan-2-one (57). To a solution of $\mathbf{5 6}^{51}$ (2.00 g, $\left.6.57 \mathrm{mmol}\right)$ in $\mathrm{CH}_{2} \mathrm{Cl}_{2}(65 \mathrm{~mL})$ at $\mathrm{rt}$ was added Dess-Martin periodinane $(4.18 \mathrm{~g}, 9.86 \mathrm{mmol})$ portionwise over 5 min. After $20 \mathrm{~h}$ the mixture was diluted with $\mathrm{Et}_{2} \mathrm{O}(30 \mathrm{~mL})$, filtered through celite (eluting with $\mathrm{Et}_{2} \mathrm{O}$ ), and concentrated in vacuo. To the residue was added sat. aq. $\mathrm{NaHCO}_{3}(50$ $\mathrm{mL})$ and $\mathrm{Na}_{2} \mathrm{~S}_{2} \mathrm{O}_{3} \cdot 5 \mathrm{H}_{2} \mathrm{O}(3.2 \mathrm{~g})$. The aqueous phase was extracted with EtOAc $(3 \times 80 \mathrm{~mL})$ and the combined organics washed with sat. brine $(50 \mathrm{~mL})$, dried over $\mathrm{MgSO}_{4}$, and concentrated in vacuo. The crude mixture was purified by flash column chromatography (Biotage Isolera One, SNAP KP-SIL $50 \mathrm{~g}$ Column, hexane/EtOAc 100:0 to 80:20) to afford the title compound 57 as a clear colourless oil (1.56 g, 79\%). $\mathrm{R}_{\mathrm{f}} 0.45$ (hexane/EtOAc 70:30); IR 3032 (w), 2867 (w), 1742 (m), 1076 (s) cm ${ }^{-1} ;{ }^{1} \mathrm{H}$ NMR (400 MHz, $\left.\mathrm{CDCl}_{3}\right) \delta$ 7.38-7.28 (10H, 
m, $\left.\mathrm{H}_{\mathrm{Ph}}\right), 5.06\left(1 \mathrm{H}\right.$, ddd, $\left.J=48.4,3.7,2.5 \mathrm{~Hz}, \mathrm{H}_{3}\right), 4.65-4.51\left(4 \mathrm{H}, \mathrm{m}, \mathrm{H}_{\mathrm{Bn}}\right), 4.48\left(2 \mathrm{H}, \mathrm{m}, \mathrm{H}_{1}\right)$, 3.99-3.83 (2H, m, H4) ppm; ${ }^{13} \mathrm{C}\left\{{ }^{1} \mathrm{H}\right\} \mathrm{NMR}\left(101 \mathrm{MHz}, \mathrm{CDCl}_{3}\right) \delta 204.3\left(\mathrm{~d}, J_{\mathrm{C}-\mathrm{F}}=24.2 \mathrm{~Hz}, \mathrm{C}_{2}\right)$, 137.1 (CPh), $137.0(\mathrm{CPh}), 128.48(\mathrm{CPh}), 128.45(\mathrm{CPh}), 128.02\left(\mathrm{CPh}_{\mathrm{Ph}}\right), 127.98(\mathrm{CPh}), 127.9(\mathrm{CPh})$, 127.7 (CPh), $94.8\left(\mathrm{~d}, J_{\mathrm{C}-\mathrm{F}}=187.1 \mathrm{~Hz}, \mathrm{C}_{3}\right), 73.7\left(\mathrm{CBn}_{\mathrm{Bn}}\right), 73.43\left(\mathrm{~d}, J_{\mathrm{C}-\mathrm{F}}=2.9 \mathrm{~Hz}, \mathrm{C}_{1}\right), 73.37\left(\mathrm{C}_{\mathrm{Bn}}\right)$, $69.5\left(\mathrm{~d}, J_{\mathrm{C}-\mathrm{F}}=19.1 \mathrm{~Hz}, \mathrm{C}_{4}\right) \mathrm{ppm} ;{ }^{19} \mathrm{~F} \mathrm{NMR}\left(376 \mathrm{MHz}, \mathrm{CDCl}_{3}\right) \delta-203.0$ to $-203.3\left(\mathrm{~m}, \mathrm{~F}_{3}\right) \mathrm{ppm}$; ${ }^{19} \mathrm{~F}\left\{{ }^{1} \mathrm{H}\right\}$ NMR $\left(376 \mathrm{MHz}, \mathrm{CDCl}_{3}\right) \delta-203.4\left(\mathrm{~s}, \mathrm{~F}_{3}\right) \mathrm{ppm}$; HRMS (ESI) m/z: [M+Na] ${ }^{+}$Calcd for $\mathrm{C}_{18} \mathrm{H}_{19} \mathrm{FNaO}_{3} 325.1210$; Found 325.1217.

1,4-Di(benzyloxy)-2,2,3-trifluorobutane (58). To a stirred solution of $\mathbf{5 7}$ (1.50 g, $4.96 \mathrm{mmol})$ in $\mathrm{CH}_{2} \mathrm{Cl}_{2}(50 \mathrm{~mL})$ cooled to $0{ }^{\circ} \mathrm{C}$ was added DAST $(3.9 \mathrm{~mL}, 30 \mathrm{mmol})$ dropwise. The solution was stirred at $\mathrm{rt}$ for $20 \mathrm{~h}$, then cooled to $0{ }^{\circ} \mathrm{C}$ and quenched by slow addition of sat. aq. $\mathrm{NaHCO}_{3}$ $(150 \mathrm{~mL})$. After stirring vigorously at $\mathrm{rt}$ for $30 \mathrm{~min}$, the phases were separated and the aqueous phase extracted with $\mathrm{CH}_{2} \mathrm{Cl}_{2}(3 \times 150 \mathrm{~mL})$. The combined organic layers were dried over $\mathrm{MgSO}_{4}$ and concentrated in vacuo. The crude mixture was purified by flash column chromatography (hexane/EtOAc 100:0 to 80:20) to afford the title compound $\mathbf{5 8}$ as a clear colourless oil (1.33 g, 83\%). Rf 0.54 (hexane/EtOAc 80:20); IR 3031 (w), 2980 (w), 2875 (w), 1113 (s), 1085 (s) cm ${ }^{-1} ;{ }^{1} \mathrm{H}$ NMR (400 MHz, $\left.\mathrm{CDCl}_{3}\right) \delta$ 7.43-7.33 (10H, m, HPh), 5.14-4.95 (1H, $\left.\mathrm{m}, \mathrm{H}_{3}\right), 4.68-4.60\left(4 \mathrm{H}, \mathrm{m}, \mathrm{H}_{\mathrm{Bn}}\right), 3.99-3.74\left(4 \mathrm{H}, \mathrm{m}, \mathrm{H}_{1+4}\right) \mathrm{ppm} ;{ }^{13} \mathrm{C}\left\{{ }^{1} \mathrm{H}\right\} \mathrm{NMR}(101 \mathrm{MHz}$, $\left.\mathrm{CDCl}_{3}\right) \delta 137.4(\mathrm{CPh}), 136.9\left(\mathrm{CPh}_{\mathrm{Ph}}\right), 128.50\left(\mathrm{CPh}_{\mathrm{Ph}}\right), 128.45\left(\mathrm{CPh}_{\mathrm{Ph}}\right), 128.0\left(\mathrm{CPh}_{\mathrm{Ph}}\right), 127.9\left(\mathrm{CPh}_{\mathrm{Ph}}\right), 127.7$ $\left(\mathrm{C}_{\mathrm{Ph}}+\mathrm{C}_{\mathrm{Ph}}\right), 119.0\left(\mathrm{td}, J_{\mathrm{C}-\mathrm{F}}=247.0,26.0 \mathrm{~Hz}, \mathrm{C}_{2}\right), 89.1\left(\mathrm{ddd}, J_{\mathrm{C}-\mathrm{F}}=181.9,33.0,26.4 \mathrm{~Hz}, \mathrm{C}_{3}\right)$, $74.0\left(\mathrm{CBn}_{\mathrm{Bn}}\right), 73.7\left(\mathrm{C}_{\mathrm{Bn}}\right), 67.6\left(\mathrm{ddd}, J_{\mathrm{C}-\mathrm{F}}=33.8,27.1,1.5 \mathrm{~Hz}, \mathrm{C}_{1}\right), 67.0\left(\mathrm{ddd}, J_{\mathrm{C}-\mathrm{F}}=21.3,4.4,2.9\right.$ $\left.\mathrm{Hz}, \mathrm{C}_{4}\right) \mathrm{ppm} ;{ }^{19} \mathrm{~F}$ NMR $\left(376 \mathrm{MHz}, \mathrm{CDCl}_{3}\right) \delta-115.5(1 \mathrm{~F}$, dddt, $J=270.8,19.4,12.4,5.6 \mathrm{~Hz}$, $\left.\mathrm{F}_{2}\right),-120.9\left(1 \mathrm{~F}, \mathrm{ddq}, J=270.5,17.8,9.7 \mathrm{~Hz}, \mathrm{~F}_{2}\right),-202.4$ to $-202.8\left(1 \mathrm{~F}, \mathrm{~m}, \mathrm{~F}_{3}\right) \mathrm{ppm} ;{ }^{19} \mathrm{~F}\left\{{ }^{1} \mathrm{H}\right\}$ $\operatorname{NMR}\left(376 \mathrm{MHz}, \mathrm{CDCl}_{3}\right) \delta-115.6\left(1 \mathrm{~F}, \mathrm{dd}, J=270.5,5.2 \mathrm{~Hz}, \mathrm{~F}_{2}\right),-121.0(1 \mathrm{~F}, \mathrm{dd}, J=270.5$, 12.1 Hz, F $\left.2^{\prime}\right),-202.7\left(1 \mathrm{~F}, \mathrm{dd}, J=12.1,5.2 \mathrm{~Hz}, \mathrm{~F}_{3}\right) \mathrm{ppm}$; HRMS (EI) m/z: $\left[\mathrm{M}-\mathrm{CH}_{2} \mathrm{Ph}\right]^{+} \mathrm{Calcd}$ for $\mathrm{C}_{11} \mathrm{H}_{12} \mathrm{~F}_{3} \mathrm{O}_{2}$ 233.0784; Found 233.0785. 
2,2,3-Trifluorobutane-1,4-diol (C5). To a solution of $\mathbf{5 8}(600 \mathrm{mg}, 1.85 \mathrm{mmol})$ in dry $\mathrm{CH}_{2} \mathrm{Cl}_{2}$ $(37 \mathrm{~mL})$ at rt, iodotrimethylsilane $(0.68 \mathrm{~mL}, 4.8 \mathrm{mmol})$ was added dropwise. After $30 \mathrm{~min}$, $\mathrm{MeOH}(6 \mathrm{~mL})$ was added and the mixture stirred for a further $30 \mathrm{~min}$. EtOAc $(15 \mathrm{~mL})$ and sat. aq. $\mathrm{NaHSO}_{3}(5 \mathrm{~mL})$ were added and the layers separated. The aqueous phase was extracted with EtOAc $(3 \times 15 \mathrm{~mL})$ and the combined organic phases washed with sat. brine $(5 \mathrm{~mL})$, dried over $\mathrm{MgSO}_{4}$, and concentrated in vacuo. The crude mixture was purified by flash column chromatography (hexane/acetone 100:0 to 60:40) to afford the title compound C5 as a crystalline solid (216 mg, 81\%). Rf 0.41 (hexane/EtOAc 40:60); mp 52-54 ${ }^{\circ} \mathrm{C}(\mathrm{MeOH})$; IR 3315 (br. m), 3200 (br. m), 2980 (m) 1229 (m), 1094 (s), 1055 (s) cm ${ }^{-1}$; ${ }^{1}$ H NMR (400 MHz, MeOD) $\delta$ 4.87-4.68 (1H, m, H3), 3.95-3.72 (4H, m, $\left.\mathrm{H}_{1+4}\right) \mathrm{ppm} ;{ }^{13} \mathrm{C}\left\{{ }^{1} \mathrm{H}\right\} \mathrm{NMR}(101 \mathrm{MHz}$, MeOD) $\delta 121.1\left(\mathrm{ddd}, J_{\mathrm{C}-\mathrm{F}}=247.2,245.0,25.7 \mathrm{~Hz}, \mathrm{C}_{2}\right), 179.7\left(\mathrm{ddd}, J_{\mathrm{C}-\mathrm{F}}=179.7,32.3,27.1\right.$ $\left.\mathrm{Hz}, \mathrm{C}_{3}\right), 61.6\left(\mathrm{ddd}, J_{\mathrm{C}-\mathrm{F}}=31.5,27.9,1.5 \mathrm{~Hz}, \mathrm{C}_{1}\right), 60.3\left(\mathrm{dt}, J_{\mathrm{C}-\mathrm{F}}=21.8,3.8 \mathrm{~Hz}, \mathrm{C}_{4}\right) \mathrm{ppm} ;{ }^{19} \mathrm{~F}$ NMR (376 MHz, MeOD) $\delta-119.3\left(1 \mathrm{~F}, \mathrm{dddt}, J=266.7,19.2,13.2,6.5 \mathrm{~Hz}, \mathrm{~F}_{2}\right),-123.5(1 \mathrm{~F}$, ddq, $\left.J=267.0,13.9,10.4 \mathrm{~Hz}, \mathrm{~F}_{2}{ }^{\prime}\right),-206.8$ to $-207.1\left(1 \mathrm{~F}, \mathrm{~m}, \mathrm{~F}_{3}\right) \mathrm{ppm} ;{ }^{19} \mathrm{~F}\left\{{ }^{1} \mathrm{H}\right\} \mathrm{NMR}(376$ $\mathrm{MHz}, \mathrm{MeOD}) \delta-119.3\left(1 \mathrm{~F}, \mathrm{dd}, J=265.3,5.2 \mathrm{~Hz}, \mathrm{~F}_{2}\right),-123.5\left(1 \mathrm{~F}, \mathrm{dd}, J=265.3,10.4 \mathrm{~Hz}, \mathrm{~F}_{2}\right)$, $-206.9\left(1 \mathrm{~F}, \mathrm{dd}, J=12.1,6.9 \mathrm{~Hz}, \mathrm{~F}_{3}\right) \mathrm{ppm}$; HRMS (EI) m/z: $\left[\mathrm{M}-\mathrm{OH}_{3}\right]^{+}$Calcd for $\mathrm{C}_{4} \mathrm{H}_{4} \mathrm{~F}_{3} \mathrm{O}$ 125.0214; Found 125.0209.

2-Fluorobutane-1,4-diol (C6). To a solution of $\mathbf{5 9}^{23}(500 \mathrm{mg}, 2.36 \mathrm{mmol})$ in $\mathrm{Et}_{2} \mathrm{O}(25 \mathrm{~mL})$ at rt, $\mathrm{NaOMe}(25 \%$ w/w in $\mathrm{MeOH}, 1.07 \mathrm{~mL}, 4.72 \mathrm{mmol})$ was added dropwise. After $16 \mathrm{~h}$, the reaction mixture was neutralized with aq. $\mathrm{HCl}(2 \mathrm{M})$ and the aqueous phase washed with $\mathrm{Et}_{2} \mathrm{O}$ $(3 \times 20 \mathrm{~mL})$. The combined organic phases were washed with brine, dried over $\mathrm{MgSO}_{4}$, and carefully concentrated $\left(30{ }^{\circ} \mathrm{C}, 750\right.$ mbar). The crude mixture was purified by flash column chromatography (Et $2 \mathrm{O} /$ acetone 95:5) to afford the title compound $\mathbf{C 6}$ as a pale-yellow oil (89 mg, 35\%). Rf 0.12 (hexane/EtOAc 40:60); IR 3313 (br. m), 2954 (m), 2892 (m), 1054 (s) cm 1, ${ }^{1} \mathrm{H}$ NMR (400 MHz, $\left.\mathrm{CDCl}_{3}\right) \delta 4.874 .81\left(1 \mathrm{H}\right.$, ddddd, $\left.J=48.9,7.9,5.5,4.6,3.4 \mathrm{~Hz}, \mathrm{H}_{2}\right)$, 
3.94-3.66 (4H, m, $\left.\mathrm{H}_{1+4}\right), 2.16-1.77\left(2 \mathrm{H}, \mathrm{m}, \mathrm{H}_{3}\right), \mathrm{ppm} ;{ }^{13} \mathrm{C}\left\{{ }^{1} \mathrm{H}\right\} \mathrm{NMR}\left(101 \mathrm{MHz}, \mathrm{CDCl}_{3}\right) \delta 92.2$ $\left(\mathrm{d}, J_{\mathrm{C}-\mathrm{F}}=168.0 \mathrm{~Hz}, \mathrm{C}_{2}\right), 64.8\left(\mathrm{~d}, J_{\mathrm{C}-\mathrm{F}}=22.7 \mathrm{~Hz}, \mathrm{C}_{1}\right), 58.5\left(\mathrm{~d}, J_{\mathrm{C}-\mathrm{F}}=5.9 \mathrm{~Hz}, \mathrm{C}_{4}\right), 33.9\left(\mathrm{~d}, J_{\mathrm{C}-\mathrm{F}}=\right.$ $\left.20.5 \mathrm{~Hz}, \mathrm{C}_{3}\right) \mathrm{ppm} ;{ }^{19} \mathrm{~F}$ NMR $\left(376 \mathrm{MHz}, \mathrm{CDCl}_{3}\right) \delta-191.5$ to $-192.0\left(\mathrm{~m}, \mathrm{~F}_{2}\right) \mathrm{ppm} ;{ }^{19} \mathrm{~F}\left\{{ }^{1} \mathrm{H}\right\}$

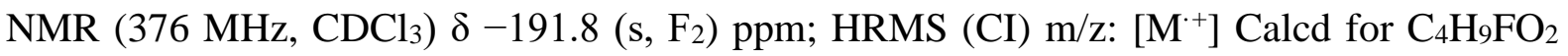
108.0581; Found 108.0580.

2,2-Difluorobutane-1,4-diol (C7). To a solution of $\mathbf{6 0}^{23}(150 \mathrm{mg}, 0.652 \mathrm{mmol})$ in $\mathrm{Et}_{2} \mathrm{O}$ (10 $\mathrm{mL})$ at $\mathrm{rt}, \mathrm{NaOMe}(25 \% \mathrm{w} / \mathrm{w}$ in $\mathrm{MeOH}, 0.30 \mathrm{~mL}, 1.30 \mathrm{mmol})$ was added dropwise. After 16 $\mathrm{h}$, the reaction mixture was neutralized with aq. $\mathrm{HCl}(2 \mathrm{M})$ and the aqueous phase washed with $\mathrm{CH}_{2} \mathrm{Cl}_{2}(3 \times 5 \mathrm{~mL})$. The combined organic phases were washed with brine, dried over $\mathrm{MgSO}_{4}$, and carefully concentrated $\left(30^{\circ} \mathrm{C}, 750 \mathrm{mbar}\right)$. The crude mixture was first purified by column chromatography (acetone/petroleum ether $\left.40-60{ }^{\circ} \mathrm{C} 50: 50\right)$ and then by HPLC ( $\mathrm{Et}_{2} \mathrm{O} /$ pentane 95:5) to afford the title compound $\mathbf{C 7}$ as a colourless crystalline solid ( $22 \mathrm{mg}, 27 \%$ ). $\mathbf{R}_{\mathrm{f}} 0.16$ (hexane/EtOAc 40:60); mp 37-39 ${ }^{\circ} \mathrm{C}(\mathrm{MeOH})$; IR (thin film, $\left.\mathrm{CDCl}_{3}\right) 3352$ (br. w), 2962 (w), 1374 (w), 1262 (m), 1066 (s), 904 (s) cm ${ }^{-1},{ }^{1} \mathrm{H}$ NMR (500 MHz, CDCl 3$) \delta 3.90$ (2H, t, J = 5.6 $\left.\mathrm{Hz}, \mathrm{H}_{4}\right), 3.83\left(2 \mathrm{H}, \mathrm{t}, J=12.6 \mathrm{~Hz}, \mathrm{H}_{1}\right), 2.69\left(1 \mathrm{H}\right.$, br. s, $\left.\mathrm{OH}_{1}\right), 2.25\left(2 \mathrm{H}, \mathrm{tt}, J=15.8,5.6 \mathrm{~Hz}, \mathrm{H}_{3}\right)$, $2.01\left(1 \mathrm{H}\right.$, br. s, $\left.\mathrm{OH}_{4}\right) \mathrm{ppm} ;{ }^{1} \mathrm{H}\left\{{ }^{19} \mathrm{~F}\right\} \mathrm{NMR}\left(500 \mathrm{MHz}, \mathrm{CDCl}_{3}\right) \delta 3.90\left(2 \mathrm{H}, \mathrm{t}, J=5.6 \mathrm{~Hz}, \mathrm{H}_{4}\right)$, $3.83\left(2 \mathrm{H}, \mathrm{s}, \mathrm{H}_{1}\right), 2.69\left(1 \mathrm{H}\right.$, br. s, OH), $2.25\left(2 \mathrm{H}, \mathrm{t}, J=5.6 \mathrm{~Hz}, \mathrm{H}_{3}\right), 2.01(1 \mathrm{H}$, br. s, OH) ppm; ${ }^{13} \mathrm{C}\left\{{ }^{1} \mathrm{H}\right\} \mathrm{NMR}\left(126 \mathrm{MHz}, \mathrm{CDCl}_{3}\right) \delta 122.9\left(\mathrm{t}, J_{\mathrm{C}-\mathrm{F}}=242.7 \mathrm{~Hz}, \mathrm{C}_{2}\right), 64.4\left(\mathrm{t}, J_{\mathrm{C}-\mathrm{F}}=33.1 \mathrm{~Hz}, \mathrm{C}_{1}\right)$, $56.9\left(\mathrm{t}, J_{\mathrm{C}-\mathrm{F}}=6.6 \mathrm{~Hz}, \mathrm{C}_{4}\right), 36.8\left(\mathrm{t}, J_{\mathrm{C}-\mathrm{F}}=24.4 \mathrm{~Hz}, \mathrm{C}_{3}\right) \mathrm{ppm} ;{ }^{19} \mathrm{~F} \mathrm{NMR}\left(471 \mathrm{MHz}, \mathrm{CDCl}_{3}\right) \delta$ $-105.1\left(\mathrm{tt}, J=15.9,12.7 \mathrm{~Hz}, \mathrm{~F}_{2}\right) \mathrm{ppm} ;{ }^{19} \mathrm{~F}\left\{{ }^{1} \mathrm{H}\right\} \mathrm{NMR}\left(471 \mathrm{MHz}, \mathrm{CDCl}_{3}\right) \delta-105.1\left(\mathrm{~s}, \mathrm{~F}_{2}\right) \mathrm{ppm}$; HRMS (CI) m/z: [M+H] $]^{+}$Calcd for $\mathrm{C}_{4} \mathrm{H}_{9} \mathrm{~F}_{2} \mathrm{O}_{2}$ 127.0561; Found 127.0566.

$(2 S, 4 S)-2,4-D i f l u o r o p e n t a n e-1,5-d i o l ~((2 S, 4 S)-H 2)$. To a stirred solution of $(2 S, 4 S)-41(200$ $\mathrm{mg}, 0.82 \mathrm{mmol})$ in $\mathrm{MeOH}(4 \mathrm{~mL})$ was added $\mathrm{KOH}(138 \mathrm{mg}, 2.46 \mathrm{mmol})$ in one portion. The mixture was stirred at $\mathrm{rt}$ for $1 \mathrm{~h}$ before addition of sat. aq. $\mathrm{NH}_{4} \mathrm{Cl}(4 \mathrm{~mL})$. The aqueous layer was extracted with EtOAc ( $3 \times 10 \mathrm{~mL})$ and the combined organic layers were dried over 
$\mathrm{MgSO}_{4}$, and concentrated in vacuo. The crude product was purified by flash column chromatography (hexane/acetone 60:40) to afford the title compound $(\mathbf{2 S , 4 S ) - H 2}$ as a white crystalline solid (91 mg, 79\%). Rf 0.20 (hexane/EtOAc 40:60); [ $\alpha]_{\mathrm{D}}{ }^{19}-31.2$ (c 1, MeOH); mp 115-116 ${ }^{\circ} \mathrm{C}(\mathrm{MeOH})$; IR 3656 (m), 3203 (br. m), 2980 (s), 2889 (m), 1382 (m) cm ${ }^{-1},{ }^{1} \mathrm{H}$ NMR (400 MHz, MeOD) $\delta$ 4.80-4.62 (2H, m, dobs, $\left.J=49.6 \mathrm{~Hz}, \mathrm{H}_{2+4}\right), 3.76-3.56$ (4H, m, $\left.\mathrm{H}_{1+5}\right), 1.99-$ $1.79\left(2 \mathrm{H}, \mathrm{m}, \mathrm{H}_{3}\right) \mathrm{ppm} ;{ }^{13} \mathrm{C}\left\{{ }^{1} \mathrm{H}\right\} \mathrm{NMR}(101 \mathrm{MHz}, \mathrm{MeOD}) \delta 92.0\left(\mathrm{dd}, J_{\mathrm{C}-\mathrm{F}}=170.2,2.9 \mathrm{~Hz}\right.$, $\left.\mathrm{C}_{2+4}\right), 65.4\left(\mathrm{~d}, J_{\mathrm{C}-\mathrm{F}}=22.0 \mathrm{~Hz}, \mathrm{C}_{1}\right), 34.4\left(\mathrm{t}, J_{\mathrm{C}-\mathrm{F}}=20.9 \mathrm{~Hz}, \mathrm{C}_{3}\right) \mathrm{ppm} ;{ }^{19} \mathrm{~F} \mathrm{NMR}(376 \mathrm{MHz}$, MeOD) $\delta-191.8$ to $-192.2\left(\mathrm{~m}, \mathrm{~F}_{2+4}\right) \mathrm{ppm} ;{ }^{19} \mathrm{~F}\left\{{ }^{1} \mathrm{H}\right\} \mathrm{NMR}(376 \mathrm{MHz}, \mathrm{MeOD}) \delta-192.1\left(\mathrm{~s}, \mathrm{~F}_{2+4}\right)$ ppm; HRMS (EI) m/z: [M-CHOH $]^{+}$Calcd for $\mathrm{C}_{4} \mathrm{H}_{8} \mathrm{~F}_{2} \mathrm{O}$ 110.0543; Found 110.0537.

The synthesis was repeated from $(\mathbf{2} \boldsymbol{R}, \mathbf{4 R})-\mathbf{4 1}(32 \mathrm{mg}, 0.13 \mathrm{mmol})$ to give $(\mathbf{2} \boldsymbol{R}, \mathbf{4 R})-\mathbf{H 2}(14 \mathrm{mg}$, $76 \%)$. Spectroscopic data was identical except $[\alpha]_{\mathrm{D}}^{20}+29.0($ c $0.15, \mathrm{MeOH})$.

2,4-syn-Difluoropentane-1,5-diol (H3). To a solution of 46 (219 mg, $1.59 \mathrm{mmol})$ in $\mathrm{MeOH}$ $(20 \mathrm{~mL})$ at $0{ }^{\circ} \mathrm{C}$ was added $\mathrm{NaBH}_{4}(150 \mathrm{mg}, 3.96 \mathrm{mmol})$ portionwise. The resulting mixture was warmed to $\mathrm{rt}$ and stirred for $3 \mathrm{~h}$. The reaction was quenched with aq. $1 \mathrm{M} \mathrm{HCl}(5 \mathrm{~mL})$, stirred for $1 \mathrm{~h}$, and concentrated in vacuo. The residue was redissolved in $\mathrm{CH}_{2} \mathrm{Cl}_{2} /$ acetone, filtered, and concentrated in vacuo. The crude product was purified by flash column chromatography (hexane/acetone 60:40) to afford the title compound $\mathbf{H 3}$ as a white crystalline solid (211 mg, 94\%). Rf 0.30 (hexane/acetone 60:40); mp 63-66 ${ }^{\circ} \mathrm{C}$ (not recrystallized); IR 3250 (br. m), 2940 (m), 1384 (m), 1068 (s), 1044 (s) cm ${ }^{-1}$; ${ }^{1} \mathrm{H}$ NMR (400 MHz, MeOD) $\delta 4.77-$ $4.60\left(2 \mathrm{H}, \mathrm{m}, \mathrm{d}_{\mathrm{obs}}, J=48.8 \mathrm{~Hz}, \mathrm{H}_{2+4}\right), 3.76-3.61\left(2 \mathrm{H}, \mathrm{m}, \mathrm{H}_{1+5}\right), 2.18-1.88\left(2 \mathrm{H}, \mathrm{m}, \mathrm{H}_{3}\right) \mathrm{ppm}$; ${ }^{13} \mathrm{C}\left\{{ }^{1} \mathrm{H}\right\}$ NMR $(101 \mathrm{MHz}, \mathrm{MeOD}) \delta 92.7\left(\mathrm{dd}, J_{\mathrm{C}-\mathrm{F}}=169.5,4.4 \mathrm{~Hz}, \mathrm{C}_{2+4}\right), 64.9\left(\mathrm{~d}, J_{\mathrm{C}-\mathrm{F}}=22.7\right.$ $\left.\mathrm{Hz}, \mathrm{C}_{1+5}\right), 33.9\left(\mathrm{t}, J_{\mathrm{C}-\mathrm{F}}=21.3 \mathrm{~Hz}, \mathrm{C}_{3}\right) \mathrm{ppm} ;{ }^{19} \mathrm{~F}$ NMR (376 MHz, MeOD) $\delta-189.2$ to -189.5 $\left(\mathrm{m}, \mathrm{F}_{2+4}\right) \mathrm{ppm} ;{ }^{19} \mathrm{~F}\left\{{ }^{1} \mathrm{H}\right\}$ NMR $(376 \mathrm{MHz}, \mathrm{MeOD}) \delta-189.2\left(\mathrm{~s}, \mathrm{~F}_{2+4}\right) \mathrm{ppm}$; HRMS (ESI) m/z: $[\mathrm{M}+\mathrm{Na}]^{+}$Calcd for $\mathrm{C}_{5} \mathrm{H}_{10} \mathrm{~F}_{2} \mathrm{NaO}_{2}$ 163.0541; Found 163.0544. 
2,2,4-Trifluoropentane-1,5-diol (H4). To a solution of $48(180 \mathrm{mg}, 0.725 \mathrm{mmol})$ in dry $\mathrm{CH}_{2} \mathrm{Cl}_{2}(1.5 \mathrm{~mL})$ at $\mathrm{rt}$, iodotrimethylsilane $(0.13 \mathrm{~mL}, 0.94 \mathrm{mmol})$ was added dropwise. After $30 \mathrm{~min}, \mathrm{MeOH}(2.4 \mathrm{~mL})$ was added. After a further $30 \mathrm{~min}$, sat. aq. sodium bisulfite $(1 \mathrm{~mL})$ and EtOAc ( $5 \mathrm{~mL})$ were added and the layers separated. The aqueous phase was extracted with EtOAc $(3 \times 5 \mathrm{~mL})$ and the combined organic phases washed with sat. brine $(1 \mathrm{~mL})$, dried over $\mathrm{MgSO}_{4}$, and concentrated in vacuo. The crude oil was purified by flash column chromatography (hexane/acetone 100:0 to 60:40) to afford the title compound $\mathbf{H 4}$ as a beige solid (83 mg, 72\%). Rf 0.09 (hexane/EtOAc 70:30); mp 60-61 ${ }^{\circ} \mathrm{C}(\mathrm{MeOH})$; IR 3344 (br. m), 2955 (w), 1078 (s), 1029 (s) cm ${ }^{-1},{ }^{1} \mathrm{H}$ NMR (400 MHz, MeOD) $\delta$ 4.90-4.72 (1H, m, dobs, $J=$ $\left.49.3 \mathrm{~Hz}, \mathrm{H}_{4}\right), 3.76-3.58\left(4 \mathrm{H}, \mathrm{m}, \mathrm{H}_{1+5}\right), 2.46-2.12\left(2 \mathrm{H}, \mathrm{m}, \mathrm{H}_{3}\right) \mathrm{ppm} ;{ }^{13} \mathrm{C}\left\{{ }^{1} \mathrm{H}\right\} \mathrm{NMR}(126 \mathrm{MHz}$, MeOD) $\delta 123.7\left(\mathrm{td}, J_{\mathrm{C}-\mathrm{F}}=242.1,1.5 \mathrm{~Hz}, \mathrm{C}_{2}\right), 90.4\left(\mathrm{ddd}, J_{\mathrm{C}-\mathrm{F}}=107.9,5.9,3.7 \mathrm{~Hz}, \mathrm{C}_{4}\right), 65.2(\mathrm{~d}$, $\left.J_{\mathrm{C}-\mathrm{F}}=22.7 \mathrm{~Hz}, \mathrm{C}_{5}\right), 64.6\left(\mathrm{td}, J_{\mathrm{C}-\mathrm{F}}=30.1,2.2 \mathrm{~Hz}, \mathrm{C}_{1}\right), 36.3\left(\mathrm{td}, J_{\mathrm{C}-\mathrm{F}}=24.2,22.0 \mathrm{~Hz}, \mathrm{C}_{3}\right) \mathrm{ppm}$; ${ }^{19} \mathrm{~F}$ NMR (471 MHz, MeOD) $\delta-105.4$ to $-106.2\left(1 \mathrm{~F}, \mathrm{~m}, \mathrm{~d}_{\mathrm{obs}}, J=251.4 \mathrm{~Hz}, \mathrm{~F}_{2}\right),-108.4$ to $-109.2\left(1 \mathrm{~F}, \mathrm{~m}\right.$, dobs, $\left.J=251.4 \mathrm{~Hz}, \mathrm{~F}_{2}\right),-188.5$ to $-188.9\left(1 \mathrm{~F}, \mathrm{~m}, \mathrm{~F}_{4}\right) \mathrm{ppm} ;{ }^{19} \mathrm{~F}\left\{{ }^{1} \mathrm{H}\right\} \mathrm{NMR}(471$ $\mathrm{MHz}, \mathrm{MeOD}) \delta-105.8\left(1 \mathrm{~F}, \mathrm{dd}, J=251.4,3.5 \mathrm{~Hz}, \mathrm{~F}_{2}\right),-108.9\left(1 \mathrm{~F}, \mathrm{dd}, J=251.4,5.2 \mathrm{~Hz}, \mathrm{~F}_{2}{ }^{\prime}\right)$, $-188.7\left(1 \mathrm{~F}, \mathrm{t}, J=5.2 \mathrm{~Hz}, \mathrm{~F}_{4}\right) \mathrm{ppm}$; HRMS (EI) m/z: $[\mathrm{M}+\mathrm{H}]^{+}$Calcd for $\mathrm{C}_{5} \mathrm{H}_{10} \mathrm{~F}_{3} \mathrm{O}_{2}$ 159.0627; Found 159.0628.

2,2,4,4-Tetrafluoropentane-1,5-diol (H5). To a stirred solution of 51 (700 mg, $1.69 \mathrm{mmol}$ ) in dry THF $(17 \mathrm{~mL})$ at $0{ }^{\circ} \mathrm{C}$ was added TBAF (1M in THF, $\left.2.5 \mathrm{~mL}, 2.5 \mathrm{mmol}\right)$ dropwise. The reaction was stirred at $\mathrm{rt}$ for $2 \mathrm{~h}$. The reaction mixture was quenched by slow addition of sat. aq. $\mathrm{NH}_{4} \mathrm{Cl}(20 \mathrm{~mL})$. After vigorous stirring for $15 \mathrm{~min}$, the aqueous phase was extracted with EtOAc $(3 \times 20 \mathrm{~mL})$ and the combined organic layers were washed with sat. brine $(20 \mathrm{~mL})$, dried over $\mathrm{MgSO}_{4}$, and concentrated in vacuo. The crude oil was purified by flash column chromatography (hexane/acetone 85:15) to afford the title compound $\mathbf{H 5}$ as a white crystalline solid (286 mg, 96\%). Rf 0.55 (hexane/acetone 60:40); mp 87-88 ${ }^{\circ} \mathrm{C}(\mathrm{MeOH}) ; \mathrm{IR} 3657$ (w), 
3343 (w), 3248 (w), 2980 (s), 2889 (m), 1387 (m), 1252 (m) cm ${ }^{-1},{ }^{1} \mathrm{H}$ NMR (400 MHz, MeOD) $\delta$ 3.80-3.63 (4H, m, $\left.\mathrm{H}_{1+5}\right), 2.67\left(2 \mathrm{H}\right.$, quin, $\left.J=16.2 \mathrm{~Hz}, \mathrm{H}_{3}\right) \mathrm{ppm} ;{ }^{13} \mathrm{C}\left\{{ }^{1} \mathrm{H}\right\} \mathrm{NMR}(101 \mathrm{MHz}$, MeOD) $\delta 122.5\left(\mathrm{tt}, J_{\mathrm{C}-\mathrm{F}}=243.7,4.2 \mathrm{~Hz}, \mathrm{C}_{2+4}\right), 65.1-64.4\left(\mathrm{~m}, \mathrm{C}_{1+5}\right), 37.3$ (quin, $J_{\mathrm{C}-\mathrm{F}}=25.1 \mathrm{~Hz}$, C3) ppm; ${ }^{19} \mathrm{~F}$ NMR (376 MHz, MeOD) $\delta-105.6$ to $-105.8\left(\mathrm{~m}, \mathrm{~F}_{2+4}\right) \mathrm{ppm} ;{ }^{19} \mathrm{~F}\{1 \mathrm{H}\} \mathrm{NMR}(376$ $\mathrm{MHz}, \mathrm{MeOD}) \delta-105.7\left(\mathrm{~s}, \mathrm{~F}_{2+4}\right) \mathrm{ppm} ; \mathrm{HRMS}(\mathrm{EI}) \mathrm{m} / \mathrm{z}:[\mathrm{M}+\mathrm{H}]^{+}$Calcd for $\mathrm{C}_{5} \mathrm{H}_{9} \mathrm{~F}_{4} \mathrm{O}_{2}$ 177.0533; Found 177.0530.

2-Fluoropentane-1,5-diol (H6). To a stirred solution of $\mathbf{5 2}^{23}$ (350 mg, $\left.1.55 \mathrm{mmol}\right)$ in $\mathrm{MeOH}$ $(7.7 \mathrm{~mL})$ at $\mathrm{rt}, \mathrm{KOH}(261 \mathrm{mg}, 4.65 \mathrm{mmol})$ was added portionwise. After $1 \mathrm{~h}$, sat. aq. $\mathrm{NH}_{4} \mathrm{Cl}$ $(8 \mathrm{~mL})$ was added and the aqueous layer extracted with EtOAc $(3 \times 20 \mathrm{~mL})$. The combined organic layers were washed with sat. brine $(10 \mathrm{~mL})$, dried over $\mathrm{MgSO}_{4}$, and concentrated in vacuo. The crude product was purified by flash column chromatography (hexane/acetone 60:40) to afford the title compound $\mathbf{H 6}$ as a yellow oil (65 mg, 34\%). Rf 0.14 (hexane /acetone, 60:40); IR 3338 (br. m), 2917 (s), 2849 (s), 1462 (w), 1043 (s) cm ${ }^{-1} ;{ }^{1} \mathrm{H}$ NMR (400 MHz, MeOD) $\delta$ 4.60-4.42 (1H, m, dobs, $\left.J=49.8 \mathrm{~Hz}, \mathrm{H}_{2}\right), 3.70-3.54\left(4 \mathrm{H}, \mathrm{m}, \mathrm{H}_{1+5}\right), 1.70-1.58(4 \mathrm{H}, \mathrm{m}$, $\left.\mathrm{H}_{3+4}\right) \mathrm{ppm} ;{ }^{13} \mathrm{C}\left\{{ }^{1} \mathrm{H}\right\} \mathrm{NMR}(101 \mathrm{MHz}, \mathrm{MeOD}) \delta 95.6\left(\mathrm{~d}, J_{\mathrm{C}-\mathrm{F}}=169.5 \mathrm{~Hz}, \mathrm{C}_{2}\right), 65.3\left(\mathrm{~d}, J_{\mathrm{C}-\mathrm{F}}=\right.$ $\left.22.7 \mathrm{~Hz}, \mathrm{C}_{1}\right), 62.7\left(\mathrm{C}_{5}\right), 29.3\left(\mathrm{~d}, J_{\mathrm{C}-\mathrm{F}}=3.7 \mathrm{~Hz}, \mathrm{C}_{4}\right), 28.8\left(\mathrm{~d}, J_{\mathrm{C}-\mathrm{F}}=21.3 \mathrm{~Hz}, \mathrm{C}_{3}\right) \mathrm{ppm} ;{ }^{19} \mathrm{~F} \mathrm{NMR}$ (376 MHz, MeOD) $\delta-189.1$ to $-189.5 \mathrm{ppm} ;{ }^{19} \mathrm{~F}\left\{{ }^{1} \mathrm{H}\right\}$ NMR (376 MHz, MeOD) $\delta-189.4$ (s, $\mathrm{F}_{2}$ ) ppm; HRMS (EI) m/z: [M+H] ${ }^{+}$Calcd for $\mathrm{C}_{5} \mathrm{H}_{12} \mathrm{FO}_{2}$ 123.0816; Found 123.0814.

3-Fluoropentane-1,5-diol (H7). To a solution of $\mathbf{5 4}(800 \mathrm{mg}, 3.88 \mathrm{mmol})$ in dry THF (3.9 $\mathrm{mL})$ at $0{ }^{\circ} \mathrm{C}$ was added a solution of $\mathrm{LiAlH}_{4}(1 \mathrm{M}$ in THF, $5.0 \mathrm{~mL}, 5.0 \mathrm{mmol})$ dropwise. The mixture was stirred at $\mathrm{rt}$ for $1 \mathrm{~h}$, then cooled to $0{ }^{\circ} \mathrm{C}$ and quenched by dropwise addition of sat. aq. Rochelle's salt $(15 \mathrm{~mL})$. EtOAc $(15 \mathrm{~mL})$ was added and the mixture stirred for $1 \mathrm{~h}$. The layers were separated and the aqueous layer extracted sequentially with EtOAc $(3 \times 15 \mathrm{~mL})$ and a mixture of $\mathrm{CHCl}_{3} / i-\mathrm{PrOH}(80: 20)(3 \times 15 \mathrm{~mL})$. The combined organic layers were 
washed with sat. brine $(15 \mathrm{~mL})$, dried over $\mathrm{MgSO}_{4}$, and concentrated in vacuo. The crude product was purified by flash column chromatography (hexane/EtOAc 60:40 to 40:60) to afford the title compound $\mathbf{H 7}$ as a yellow oil (257 mg, 54\%). Rf 0.10 (hexane/EtOAc 60:40); IR 3311 (br. s), 2955 (m), 1395 (m), 1043 (s) cm ${ }^{-1} ;{ }^{1} \mathrm{H}$ NMR (400 MHz, $\left.\mathrm{CDCl}_{3}\right) \delta 4.95(1 \mathrm{H}$, $\left.\mathrm{dtt}, J=49.8,8.8,3.4 \mathrm{~Hz}, \mathrm{H}_{3}\right), 3.86-3.82\left(4 \mathrm{H}, \mathrm{m}, \mathrm{H}_{1+5}\right), 2.03-1.79\left(4 \mathrm{H}, \mathrm{m}, \mathrm{H}_{2+4}\right) \mathrm{ppm} ;{ }^{13} \mathrm{C}\left\{{ }^{1} \mathrm{H}\right\}$ NMR $\left(101 \mathrm{MHz}, \mathrm{CDCl}_{3}\right) \delta 90.6\left(\mathrm{~d}, J_{\mathrm{C}-\mathrm{F}}=165.1 \mathrm{~Hz}, \mathrm{C}_{3}\right), 59.2\left(\mathrm{~d}, J_{\mathrm{C}-\mathrm{F}}=5.1 \mathrm{~Hz}, \mathrm{C}_{1+5}\right), 37.9(\mathrm{~d}$, $\left.J_{\mathrm{C}-\mathrm{F}}=19.8 \mathrm{~Hz}, \mathrm{C}_{2+4}\right) \mathrm{ppm} ;{ }^{19} \mathrm{~F} \mathrm{NMR}\left(376 \mathrm{MHz}, \mathrm{CDCl}_{3}\right) \delta-184.6(\mathrm{dtt}, J=50.3,33.0,17.3 \mathrm{~Hz}$, $\left.\mathrm{F}_{3}\right) \mathrm{ppm} ;{ }^{19} \mathrm{~F}\left\{{ }^{1} \mathrm{H}\right\}$ NMR $\left(376 \mathrm{MHz}, \mathrm{CDCl}_{3}\right) \delta-187.4\left(\mathrm{~s}, \mathrm{~F}_{3}\right)$ ppm; HRMS (EI) m/z: $[\mathrm{M}+\mathrm{H}]^{+}$ Calcd for $\mathrm{C}_{5} \mathrm{H}_{12} \mathrm{FO}_{2}$ 123.0816; Found 123.0821.

2,2-Difluoropentane-1,5-diol (H8). To a solution of $\mathbf{5 5}^{23}(0.20 \mathrm{~g}, 0.80 \mathrm{mmol})$ in $\mathrm{Et}_{2} \mathrm{O}(8 \mathrm{~mL})$ at $\mathrm{rt}, \mathrm{NaOMe}(25 \% \mathrm{w} / \mathrm{w}$ in $\mathrm{MeOH}, 750 \mu \mathrm{L}, 3.6 \mathrm{mmol})$ was added dropwise. After $16 \mathrm{~h}$ the reaction mixture was filtered through a silica plug (eluting with EtOAc) and concentrated in vacuo. The crude product was purified by flash column chromatography (petroleum ether /acetone, 80:22 to 60:40) to afford the title compound $\mathbf{H 8}$ as a colourless oil (31 $\mathrm{mg}, 27 \%)$. Rf 0.32 (hexane/acetone, 60:40); IR 3331 (br. m), 2943 (m), 2883 (m), 1179 (m), 1054 (s), 1004 (s) $\mathrm{cm}^{-1} ;{ }^{1} \mathrm{H}$ NMR (400 MHz, MeOD) $\delta 3.65\left(2 \mathrm{H}, \mathrm{t}, J=13.1 \mathrm{~Hz}, \mathrm{H}_{1}\right), 3.59(2 \mathrm{H}, \mathrm{t}, J=6.5 \mathrm{~Hz}$, $\left.\mathrm{H}_{5}\right)$, 2.04-1.91 (2H, m, H3), 1.74-1.67 (2H, m, $\left.\mathrm{H}_{4}\right) \mathrm{ppm} ;{ }^{13} \mathrm{C}\left\{{ }^{1} \mathrm{H}\right\}$ NMR (101 MHz, MeOD) $\delta$ $125.0\left(\mathrm{t}, J_{\mathrm{C}-\mathrm{F}}=241.0 \mathrm{~Hz}, \mathrm{C}_{2}\right), 64.4\left(\mathrm{t}, J_{\mathrm{C}-\mathrm{F}}=32.3 \mathrm{~Hz}, \mathrm{C}_{1}\right), 62.5\left(\mathrm{C}_{5}\right), 31.0\left(\mathrm{t}, J_{\mathrm{C}-\mathrm{F}}=24.6 \mathrm{~Hz}\right.$, $\left.\mathrm{C}_{3}\right), 26.2\left(\mathrm{t}, J_{\mathrm{C}-\mathrm{F}}=4.4 \mathrm{~Hz}, \mathrm{C}_{4}\right) \mathrm{ppm} ;{ }^{19} \mathrm{~F} \mathrm{NMR}(376 \mathrm{MHz}, \mathrm{MeOD}) \delta-109.1(\mathrm{tt}, J=17.3,12.1$ $\left.\mathrm{Hz}, \mathrm{F}_{2}\right) \mathrm{ppm} ;{ }^{19} \mathrm{~F}\left\{{ }^{1} \mathrm{H}\right\} \mathrm{NMR}(376 \mathrm{MHz}, \mathrm{MeOD}) \delta-109.1$ (s, F2) ppm; HRMS (EI) m/z: $[\mathrm{M}-\mathrm{CHOH}]^{+}$Calcd for $\mathrm{C}_{4} \mathrm{H}_{8} \mathrm{~F}_{2} \mathrm{O}$ 110.0538; Found 110.0537.

\section{Acknowledgements}


We are grateful to AstraZeneca for a CASE award, and to the EPSRC for a CASE conversion grant (EP/M508147/1) and instrument funding (core capability EP/K039466/1).

Supporting Information: ${ }^{1} \mathrm{H},{ }^{13} \mathrm{C},{ }^{19} \mathrm{~F}$ NMR spectra of all novel compounds, $\operatorname{cog} P$ determination of 1,5-pentanediol, comparison of the experimental with the $\operatorname{cog} P$ values of all fluorinated diols, experimental $\log P$ determination data. This material is available free of charge via the Internet at http://pubs.acs.org/. The raw NMR data files are available free of charge at http://dx.doi.org/xxxxxxxxxxxxxx

*To whom correspondence should be addressed.

\section{References}

1. Meanwell, N. A., Improving Drug Candidates by Design: A Focus on Physicochemical Properties As a Means of Improving Compound Disposition and Safety. Chem. Res. Toxicol. 2011, 24 (9), 1420-1456.

2. Meanwell, N. A., Improving Drug Design: An Update on Recent Applications of Efficiency Metrics, Strategies for Replacing Problematic Elements, and Compounds in Nontraditional Drug Space. Chem. Res. Toxicol. 2016, 29 (4), 564-616.

3. Wenlock, M. C.; Austin, R. P.; Barton, P.; Davis, A. M.; Leeson, P. D., A comparison of physiochemical property profiles of development and marketed oral drugs. $J$. Med. Chem. 2003, 46 (7), 1250-1256.

4. Gleeson, M. P.; Hersey, A.; Montanari, D.; Overington, J., Probing the Links Between in vitro Potency, ADMET and physicochemical Parameters. Nat. Rev. Drug Disc. 2011, 10 (3), 197-208.

5. Waring, M. J.; Arrowsmith, J.; Leach, A. R.; Leeson, P. D.; Mandrell, S.; Owen, R. M.; Pairaudeau, G.; Pennie, W. D.; Pickett, S. D.; Wang, J.; Wallace, O.; Weir, A., An analysis of the attrition of drug candidates from four major pharmaceutical companies. Nat. Rev. Drug Discov. 2015, 14 (7), 475-486.

6. Lipinski, C. A.; Lombardo, F.; Dominy, B. W.; Feeney, P. J., Experimental and computational approaches to estimate solubility and permeability in drug discovery and development settings. Adv. Drug Deliv. Rev. 1997, 23 (1), 3-25.

7. Young, R. J.; Leeson, P. D., Mapping the Efficiency and Physicochemical Trajectories of Successful Optimizations. J. Med. Chem. 2018, 61 (15), 6421-6467.

8. $\quad$ Bunally, S. B.; Luscombe, C. N.; Young, R. J., Using Physicochemical Measurements to Influence Better Compound Design. SLAS Discovery 2019, 24 (8), 791-801. 9. Waring, M. J., Lipophilicity in Drug Discovery. Exp. Opin. Drug Discov. 2010, 5 (3), 235-248. 
10. Arnott, J. A.; Planey, S. L., The influence of lipophilicity in drug discovery and design. Exp. Opin. Drug Discov. 2012, 7, 863-875.

11. Scott, J. S.; Waring, M. J., Practical Application of Ligand Efficiency Metrics in Lead Optimisation. Bioorg. Med. Chem. 2018, 26 (11), 3006-3015.

12. Giaginis, C.; Tsantili-Kakoulidou, A., Alternative Measures of Lipophilicity: From Octanol-Water Partitioning to IAM Retention. J. Pharm. Sci. 2008, 97 (8), 2984-3004.

13. Young, R. J.; Green, D. V. S.; Luscombe, C. N.; Hill, A. P., Getting Physical in Drug Discovery II: the Impact of Chromatographic Hydrophobicity Measurements and Aromaticity. Drug Discov. Today 2011, 16 (17-18), 822-830.

14. Wu, Y. M.; Salas, Y. L.; Leung, Y. C.; Hunter, L.; Ho, J., Predicting Octanol-Water Partition Coefficients of Fluorinated Drug-Like Molecules: A Combined Experimental and Theoretical Study. Aust. J. Chem. 2020.

15. Kundi, V.; Ho, J., Predicting Octanol-Water Partition Coefficients: Are Quantum Mechanical Implicit Solvent Models Better than Empirical Fragment-Based Methods? J. Phys. Chem. B 2019, 123 (31), 6810-6822.

16. Meanwell, N. A., Fluorine and Fluorinated Motifs in the Design and Application of Bioisosteres for Drug Design. J. Med. Chem. 2018, 61, 5822-5880.

17. Huchet, Q. A.; Kuhn, B.; Wagner, B.; Fischer, H.; Kansy, M.; Zimmerli, D.; Carreira, E. M.; Müller, K., On the Polarity of Partially Fluorinated Methyl Groups. J. Fluorine Chem. 2013, 152, 119-128.

18. Muller, K., Simple Vector Considerations to Assess the Polarity of Partially Fluorinated Alkyl and Alkoxy Groups. Chimia 2014, 68 (6), 356-362.

19. Huchet, Q. A.; Kuhn, B.; Wagner, B.; Kratochwil, N. A.; Fischer, H.; Kansy, M.; Zimmerli, D.; Carreira, E. M.; Muller, K., Fluorination Patterning: A Study of Structural Motifs That Impact Physicochemical Properties of Relevance to Drug Discovery. J. Med. Chem. 2015, 58 (22), 9041-60.

20. Vorberg, R.; Trapp, N.; Zimmerli, D.; Wagner, B.; Fischer, H.; Kratochwil, N. A.; Kansy, M.; Carreira, E. M.; Muller, K., Effect of Partially Fluorinated N-Alkyl-Substituted Piperidine-2-carboxamides on Pharmacologically Relevant Properties. ChemMedChem 2016, 11 (19), 2216-2239.

21. Huchet, Q. A.; Trapp, N.; Kuhn, B.; Wagner, B.; Fischer, H.; Kratochwil, N. A.; Carreira, E. M.; Müller, K., Partially Fluorinated Alkoxy Groups - Conformational Adaptors to Changing Environments. J. Fluorine Chem. 2017, 198, 34-46.

22. Müller, K., Fluorination Patterns in Small Alkyl Groups: Their Impact on Properties Relevant to Drug Discovery. In Fluorine in Life Sciences: Pharmaceuticals, Medicinal Diagnostics, and Agrochemicals, Haufe, G.; Leroux, F., Eds. Academic Press: 2018.

23. Jeffries, B.; Wang, Z.; Felstead, H. R.; Le Questel, J. Y.; Scott, J. S.; Chiarparin, E.; Graton, J.; Linclau, B., A Systematic Investigation of Lipophilicity Modulation by Aliphatic Fluorination Motifs. J. Med. Chem. 2020, 63 (3), 1002-1031.

24. Zafrani, Y.; Sod-Moriah, G.; Yeffet, D.; Berliner, A.; Amir, D.; Marciano, D.; Elias, S.; Katalan, S.; Ashkenazi, N.; Madmon, M.; Gershonov, E.; Saphier, S., CF2H, a Functional Group-Dependent Hydrogen-Bond Donor: Is It a More or Less Lipophilic Bioisostere of $\mathrm{OH}, \mathrm{SH}$, and CH3? J. Med. Chem. 2019, 62 (11), 5628-5637. 25. Jeffries, B.; Wang, Z.; Graton, J.; Holland, S. D.; Brind, T.; Greenwood, R. D. R.; Le Questel, J.-Y.; Scott, J. S.; Chiarparin, E.; Linclau, B., Reducing the Lipophilicity of Perfluoroalkyl Groups by CF2-F/CF2-Me or CF3/CH3 Exchange. J. Med. Chem. 2018, 61, 10602-10618.

26. Zafrani, Y.; Yeffet, D.; Sod-Moriah, G.; Berliner, A.; Amir, D.; Marciano, D.; Gershonov, E.; Saphier, S., Difluoromethyl Bioisostere: Examining the "Lipophilic Hydrogen Bond Donor" Concept. J. Med. Chem. 2017, 60 (2), 797-804. 
27. Linclau, B.; Wang, Z.; Compain, G.; Paumelle, V.; Fontenelle, C. Q.; Wells, N.; Weymouth-Wilson, A., Investigating the Influence of (Deoxy)fluorination on the Lipophilicity of Non-UV-Active Fluorinated Alkanols and Carbohydrates by a New $\log \mathrm{P}$ Determination Method. Angew. Chem. Int. Ed. 2016, 55 (2), 674-678.

28. Tomita, R.; Al-Maharik, N.; Rodil, A.; Buhl, M.; O'Hagan, D., Synthesis of Aryl alpha,alpha-Difluoroethyl Thioethers a Novel Structure Motif in Organic Chemistry, and Extending to Aryl alpha,alpha-Difluoro Oxyethers. Org. Biomol. Chem. 2018, 16, 11131117.

29. Jeffries, B.; Wang, Z.; Troup, R. I.; Goupille, A.; Le Questel, J.-Y.; Fallan, C.; Scott, J. S.; Chiarparin, E.; Graton, J.; Linclau, B., Lipophilicity trends upon fluorination of isopropyl, cyclopropyl and 3-oxetanyl groups. Beilst. J. Org. Chem. 2020, 16, 2141-2150.

30. Chernykh, A. V.; Olifir, O. S.; Kuchkovska, Y. O.; Volochnyuk, D. M.;

Yarmolchuk, V. S.; Grygorenko, O. O., Fluoroalkyl-Substituted Cyclopropane Derivatives: Synthesis and Physicochemical Properties. J. Org. Chem. 2020.

31. Fang, Z.; Cordes, D. B.; Slawin, A. M. Z.; O'Hagan, D., Fluorine containing cyclopropanes: synthesis of aryl substituted all-cis 1,2,3-trifluorocyclopropanes, a facially polar motif. Chem. Commun. 2019, 55 (71), 10539-10542.

32. Thomson, C. J.; Zhang, Q.; Al-Maharik, N.; Bühl, M.; Cordes, D. B.; Slawin, A. M. Z.; O'Hagan, D., Fluorinated cyclopropanes: synthesis and chemistry of the aryl $\alpha, \beta, \beta-$ trifluorocyclopropane motif. Chem. Commun. 2018, 54 (60), 8415-8418.

33. Mukherjee, P.; Pettersson, M.; Dutra, J. K.; Xie, L. F.; Ende, C. W. A., Trifluoromethyl Oxetanes: Synthesis and Evaluation as a tert-Butyl Isostere. ChemMedChem 2017, 12 (19), 1574-1577.

34. Logvinenko, I. G.; Markushyna, Y.; Kondratov, I. S.; Vashchenko, B. V.; Kliachyna, M.; Tokaryeva, Y.; Pivnytska, V.; Grygorenko, O. O.; Haufe, G., Synthesis, physico-chemical properties and microsomal stability of compounds bearing aliphatic trifluoromethoxy group. J. Fluorine Chem. 2020, 109461.

35. Kondratov, I. S.; Logvinenko, I. G.; Tolmachova, N. A.; Morev, R. N.; Kliachyna, M. A.; Clausen, F.; Daniliuc, C. G.; Haufe, G., Synthesis and physical chemical properties of 2-amino-4-(trifluoromethoxy)butanoic acid - a CF3O-containing analogue of natural lipophilic amino acids. Org. Biomol. Chem. 2017, 15 (3), 672-679.

36. Kubyshkin, V., Polarity effects in 4-fluoro- and 4-(trifluoromethyl)prolines. Beilst. J. Org. Chem. 2020, 16, 1837-1852.

37. Erdeljac, N.; Kehr, G.; Ahlqvist, M.; Knerr, L.; Gilmour, R., Exploring Physicochemical Space via a Bioisostere of the Trifluoromethyl and Ethyl Groups (BITE): Attenuating Lipophilicity in Fluorinated Analogues of Gilenya(R) for Multiple Sclerosis. Chem. Commun. 2018, 54 (85), 12002-12005.

38. Bentler, P.; Erdeljac, N.; Bussmann, K.; Ahlqvist, M.; Knerr, L.; Bergander, K.; Daniliuc, C. G.; Gilmour, R., Stereocontrolled Synthesis of Tetrafluoropentanols: Multivicinal Fluorinated Alkane Units for Drug Discovery. Org. Lett. 2019, 21 (19), 77417745.

39. Rodil, A.; Bosisio, S.; Ayoup, M. S.; Quinn, L.; Cordes, D. B.; Slawin, A. M. Z.; Murphy, C. D.; Michel, J.; O'Hagan, D., Metabolism and hydrophilicity of the polarised 'Janus face' all-cis tetrafluorocyclohexyl ring, a candidate motif for drug discovery. Chem. Sci. 2018, 9 (11), 3023-3028.

40. Banik, S. M.; Mennie, K. M.; Jacobsen, E. N., Catalytic 1,3-Difunctionalization via Oxidative C-C Bond Activation. J. Am. Chem. Soc. 2017, 139 (27), 9152-9155.

41. Fischer, S.; Huwyler, N.; Wolfrum, S.; Carreira, E. M., Synthesis and Biological Evaluation of Bromo- and Fluorodanicalipin A. Angew. Chem. Int. Ed. 2016, 55 (7), 25552558. 
42. Terjeson, R. J.; Gard, G. L., New pentafluorothio(SF5)fluoropolymers. J. Fluorine Chem. 1987, 35 (4), 653-662.

43. Cheng, Y.; Muck-Lichtenfeld, C.; Studer, A., Transition Metal-Free 1,2-

Carboboration of Unactivated Alkenes. J. Am. Chem. Soc. 2018, 140 (20), 6221-6225.

44. Kitazume, T.; Ishikawa, N., Asymmetrical Reduction of Perfluoroalkylated Ketones, Ketoesters and Vinyl Compounds with Baker's Yeast. Chem. Lett. 1983, 12 (2), 237-238.

45. Fuchikami, T.; Ojima, I., Transition-metal complex catalyzed polyfluoroalkylation. I. Facile addition of polyfluoroalkyl halides to carbon-carbon multiple bonds. Tetrahedron Lett. 1984, 25 (3), 303-306.

46. Boutevin, G.; Tiffes, D.; Loubat, C.; Boutevin, B.; Ameduri, B., New fluorinated surfactants based on vinylidene fluoride telomers. J. Fluorine Chem. 2012, 134, 77-84. 47. Balague, J.; Ameduri, B.; Boutevin, B.; Caporiccio, G., Synthesis of fluorinated telomers. Part 1. Telomerization of vinylidene fluoride with perfluoroalkyl iodides. $J$. Fluorine Chem. 1995, 70 (2), 215-223.

48. Yake, A.; Corder, T.; Moloy, K.; Coope, T.; Taylor, C.; Hung, M.; Peng, S., Fluorinated pyridinium and ammonium cationic surfactants. J. Fluorine Chem. 2016, 187, 46-55.

49. Wang, Y.; Callejo, R.; Slawin, A. M. Z.; O'Hagan, D., The Difluoromethylene (CF2) Group in Aliphatic Chains: Synthesis and Conformational Preference of Palmitic Acids and Nonadecane Containing CF2 Groups. Beilst. J. Org. Chem. 2014, 10, 18-25.

50. Ivasyshyn, V.; Smit, H.; Chiechi, R. C., Synthesis of a Hominal Bis(difluoromethyl) Fragment. ACS Omega 2019, 4 (9), 14140-14150.

51. Szpera, R.; Kovalenko, N.; Natarajan, K.; Paillard, N.; Linclau, B., The synthesis of the 2,3-difluorobutan-1,4-diol diastereomers. Beilst. J. Org. Chem. 2017, 13, 2883-2887. 52. McAtee, J. J.; Schinazi, R. F.; Liotta, D. C., A Completely Diastereoselective Electrophilic Fluorination of a Chiral, Noncarbohydrate Sugar Ring Precursor: Application to the Synthesis of Several Novel 2'-Fluoronucleosides. J. Org. Chem. 1998, 63 (7), 21612167.

53. Beach, J. W.; Kim, H. O.; Jeong, L. S.; Nampalli, S.; Islam, Q.; Ahn, S. K.; Babu, J. R.; Chu, C. K., A highly stereoselective synthesis of anti-HIV 2',3'-dideoxy- and 2',3'didehydro-2',3'-dideoxynucleosides. J. Org. Chem. 1992, 57 (14), 3887-3894.

54. Cai, X.; Chorghade, M. S.; Fura, A.; Grewal, G. S.; Jauregui, K. A.; Lounsbury, H. A.; Scannell, R. T.; Yeh, C. G.; Young, M. A.; Yu, S.; Guo, L.; Moriarty, R. M.;

Penmasta, R.; Rao, M. S.; Singhal, R. K.; Song, Z.; Staszewski, J. P.; Tuladhar, S. M.; Yang, S., Synthesis of CMI-977, a Potent 5-Lipoxygenase Inhibitor. Org. Process Res. Dev. 1999, 3 (1), 73-76.

55. Beeson, T. D.; MacMillan, D. W. C., Enantioselective Organocatalytic $\alpha$-Fluorination of Aldehydes. J. Am. Chem. Soc. 2005, 127 (24), 8826-8828.

56. Denavit, V.; Lainé, D.; St-Gelais, J.; Johnson, P. A.; Giguère, D., A Chiron Approach Towards the Stereoselective Synthesis of Polyfluorinated Carbohydrates. Nat.

Commun. 2018, 9 (1), 4721.

57. Quiquempoix, L.; Wang, Z.; Graton, J.; Latchem, P. G.; Light, M.; Le Questel, J. Y.; Linclau, B., Synthesis of 2,3,4-Trideoxy-2,3,4-trifluoroglucose. J. Org. Chem. 2019, 84 (9), 5899-5906.

58. Fadeyi, O. O.; Lindsley, C. W., Rapid, General Access to Chiral beta-Fluoroamines and beta,beta-Difluoroamines via Organocatalysis. Org. Lett. 2009, 11 (4), 943-946.

59. O'Reilly, M. C.; Lindsley, C. W., A General, Enantioselective Synthesis of Beta- and Gamma-Fluoroamines. Tetrahedron Lett. 2013, 54 (28), 3627-3629. 
60. Kim, B. C.; Park, A.; An, J. E.; Lee, W. K.; Lee, H. B.; Shin, H., Highly Improved Copper-Mediated Michael Addition of Ethyl Bromodifluoroacetate in the Presence of Protic Additive. Synthesis 2012, 44 (20), 3165-3170.

61. Sato, K.; Tamura, M.; Tamoto, K.; Omote, M.; Ando, A.; Kumadaki, I., Michaeltype Reaction of Ethyl Bromodifluoroacetate with \&alpha; \&beta;-Unsaturated Carbonyl Compounds in the Presence of Copper Powder. Chem. Pharm. Bull. 2000, 48 (7), 1023-1025. 62. Sato, K.; Nakazato, S.; Enko, H.; Tsujita, H.; Fujita, K.; Yamamoto, T.; Omote, M.; Ando, A.; Kumadaki, I., 1,4-Addition reaction of ethyl bromodifluoroacetate to Michael acceptors in the presence of copper powder: Improvement of the reaction using TMEDA as an additive. J. Fluorine Chem. 2003, 121, 105-107.

63. Xu, Y.; Qian, L.; Prestwich, G. D., Synthesis of Monofluorinated Analogues of Lysophosphatidic Acid. J. Org. Chem. 2003, 68 (13), 5320-5330.

64. Labelle, M.; Morton, H. E.; Guindon, Y.; Springer, J. P., Homoallylic chiral induction in the synthesis of 2,4-disubstituted tetrahydrofurans by iodoetherification. Synthetic scope and chiral induction mechanism. J. Am. Chem. Soc. 1988, 110 (14), 45334540 .

65. Kirwan, J. N.; Roberts, B. P.; Willis, C. R., Deoxygenation of alcohols by the reactions of their xanthate esters with triethylsilane: An alternative to tributyltin hydride in the Barton-McCombie reaction. Tetrahedron Lett. 1990, 31 (35), 5093-5096.

66. Rui, F.; Boland, W., Algal Pheromone Biosynthesis: Stereochemical Analysis and Mechanistic Implications in Gametes of Ectocarpus siliculosus. J. Org. Chem. 2010, 75 (12), 3958-3964.

67. Jung, M. E.; Lyster, M. A., Quantitative dealkylation of alkyl ethers via treatment with trimethylsilyl iodide. A new method for ether hydrolysis. J. Org. Chem. 1977, 42 (23), 3761-3764.

68. Kasuya, M. C. Z.; Nakano, S.; Katayama, R.; Hatanaka, K., Evaluation of the hydrophobicity of perfluoroalkyl chains in amphiphilic compounds that are incorporated into cell membrane. J. Fluorine Chem. 2011, 132 (3), 202-206.

69. Johnson, B. M.; Shu, Y. Z.; Zhuo, X.; Meanwell, N. A., Metabolic and Pharmaceutical Aspects of Fluorinated Compounds. J. Med. Chem. 2020, 63 (12), 63156386.

70. Pan, Y., The Dark Side of Fluorine. ACS Medicinal Chemistry Letters 2019, 10 (7), 1016-1019.

71. Wang, L. F.; Wei, J.; Wu, R. R.; Cheng, G.; Li, X. J.; Hu, J. B.; Hu, Y. Z.; Sheng, R., The Stability and Reactivity of Tri-, Di-, and Monofluoromethyl/Methoxy/Methylthio Groups on Arenes under Acidic and Basic Conditions. Organic Chemistry Frontiers 2017, 4 (2), 214-223.

72. Zottola, M.; Rao, B. V.; Fraser-Reid, B., A mild procedure for cleavage of 1,6anhydro sugars. J. Chem. Soc., Chem. Commun. 1991, (14), 969-970. 